\title{
AUTHOR AUTONOMY AND ATOMISM IN COPYRIGHT LAW
}

\author{
Molly Shaffer Van Houweling*
}

INTRODUCTION 551

I. THREE DIMENSIONS OF ATOMISM …........................................556

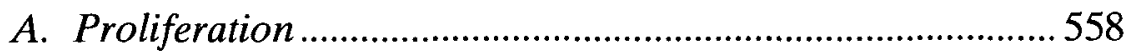

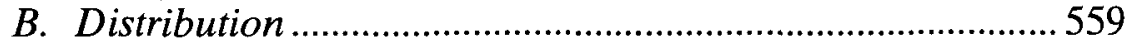

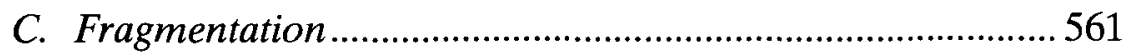

D. Atomism Across Multiple Dimensions...............................565

II. ATOMISM IN HISTORICAL PERSPECTIVE ......................................566

A. The Pre-Modern Era: Proto-Copyright and the

Stationers' Company ........................................................... 566

1. Proliferation: How Many Works Are Subject to

Ownership?.....

*Assistant Professor of Law, University of California, Berkeley. Anyone may make verbatim copies of this article so long as the following notice is retained on all publicly distributed copies:

(C2010 Virginia Law Review Association. Originally published in the Virginia Law Review. Licensed under the Creative Commons Attribution-NoDerivs 3.0 Unported License. To view a copy of this license, visit http://creativecommons.org/licenses/bynd/3.0/ or send a letter to Creative Commons, 171 Second St., Suite 300, San Francisco, California, 94105, USA.

Thanks to Julie Alimi-Londner, Carolina Gómez, Jade Hoffman, David Kayvanfar, and Jeslyn Miller for excellent research assistance, and to Catherine Albiston, Gregory Alexander, Michelle Wilde Anderson, Kenneth Bamberger, Eric Biber, James Boyle, David Caron, Michael Carroll, Julie Cohen, Holly Doremus, Aaron Edlin, Lee Anne Fennell, Jill Fisch, Catherine Fisk, David Gamage, H. Tomás GómezArostegui, Andrew Guzman, Kinch Hoekstra, Justin Hughes, Amy Kapczynski, Lawrence Lessig, Joseph Liu, Michael Madison, Jonathan Masur, Stephen Maurer, Peter Menell, Robert Merges, Michael Meurer, Justin McCrary, Adam Mossoff, Melissa Murray, Erin Murphy, Anne Joseph O'Connell, Pamela Samuelson, Joseph Sax, Jason Schultz, Paul Schwartz, Suzanne Scotchmer, Howard Shelanski, Henry Smith, Sarah Song, Simon Stern, Stewart Sterk, Talha Syed, Eric Talley, Rebecca Tushnet, Jennifer Urban, Jan Vetter, Philip Weiser, Felix Wu, Tim Wu, Alfred Yen, Jonathan Zittrain, and participants in the Intellectual Property Scholars Conference at Cardozo Law School, the Law and New Institutional Economics Workshop at the University of Colorado Law School, the Columbia Law School Intellectual Property Colloquium, the Property Works in Progress Conference at the University of Colorado Law School, the Cyberlaw Colloquium at American University Washington College of Law, and the Berkeley Law Intellectual Property Scholarship Seminar for their helpful comments and conversations.

I serve on the Board of Directors of Creative Commons, an organization discussed below. The views expressed about Creative Commons are my own. 
2. Distribution: How Many People Own Rights?

3. Fragmentation: Among How Many People Is Each Work Divided?

4. Atomism Across Multiple Dimensions........................... 574

B. The Early Modern Era: Eighteenth-Century Great Britain Under the Statute of Anne

1. Proliferation: How Many Works Are Subject to Ownership?

2. Distribution: How Many People Own Rights?

3. Fragmentation: Among How Many People Is Each Work Divided?

4. Atomism Across Multiple Dimensions.

C. Nineteenth-Century Copyright in the United States. 585

1. Proliferation: How Many Works Are Subject to Ownership?

2. Distribution: How Many People Own Rights?............. 589

3. Fragmentation: Among How Many People Is Each Work Divided?

4. Atomism Across Multiple Dimensions.......................... 592

D. Atomism Anxiety at the Turn of the Twentieth Century.... 593

1. Proliferation: How Many Works Are Subject to

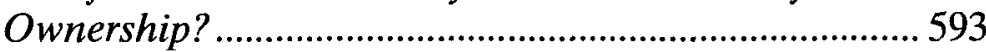

2. Distribution: How Many People Own Rights?............. 594

3. Fragmentation: Among How Many People Is Each Work Divided?

4. Atomism Anxiety Across Multiple Dimensions ............ 604

E. The 1976 Act and the Age of the Author............................ 604

1. Proliferation: How Many Works Are Subject to

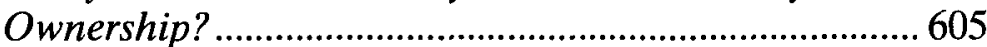

2. Distribution: How Many People Own Rights?.............. 606

3. Fragmentation: Among How Many People Is Each

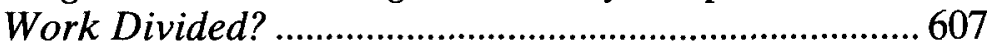

4. Atomism Across Multiple Dimensions............................613

III. ATOMISM AND AUTONOMY IN THE INTERNET AGE..................613

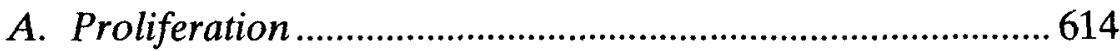

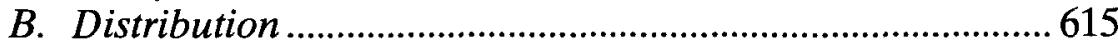

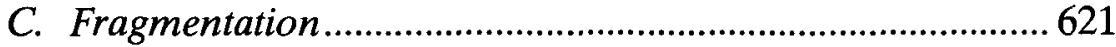

D. Atomism Across Multiple Dimensions ................................ 629 
IV. Alleviating Atomism While Honoring Autonomy in CONTEMPORARY COPYRIGHT

\section{INTRODUCTION}

THE power and ubiquity of personal computing and the 1 Internet have enabled individuals-even impecunious amateurs-to create and communicate in ways that were previously possible only for well-funded corporate publishers. Most observers have celebrated this development, noting its potential to diversify and democratize media and creative culture. In the popular press, buzzwords like "user-generated content," "Web 2.0," "crowdsourcing," "citizen journalism," and "the Living Web" describe and hype this phenomenon. ${ }^{1}$ Legal scholars have been among the cheerleaders: praising technology's potential to facilitate "cheap speech," to promote "semiotic democracy," and to enhance individual autonomy by "giv[ing] individuals a significantly greater role in authoring their own lives."

Much of the creativity empowered by digital technology incorporates existing copyrighted works and is therefore regulated by copyright law. ${ }^{5}$ Although some copyright holders tolerate or even

\footnotetext{
${ }^{1}$ See, e.g., Dan Gillmor, We the Media: Grassroots Journalism by the People, for the People xxix (2006) (describing citizen journalism); Jeff Howe, Crowdsourcing: Why the Power of the Crowd is Driving the Future of Business 8 (2008); Steven Levy \& Brad Stone, The New Wisdom of the Web, Newsweek, Apr. 3, 2006, at 47-48 (describing the living web); Tim O'Reilly, What is Web 2.0: Design Patterns and Business Models for the Next Generation of Software, O'Reilly, Sept. 30, 2005, http://www.oreillynet.com/pub/a/oreilly/tim/news/2005/09/30/what-is-web-20.html.

There have been skeptics as well. See, e.g., Andrew Keen, The Cult of the Amateur: How Today's Internet is Killing our Culture 15 (2007) (arguing that democratization of media "is threatening the very future of our cultural institutions"); see also Nicholas Carr, The Big Switch: Rewiring the World, From Edison to Google (2008); Mark Helprin, Digital Barbarism: A Writer's Manifesto (2009).

${ }^{2}$ Eugene Volokh's work, written a decade before the Web 2.0 hype, is especially prescient. See Eugene Volokh, Cheap Speech and What It Will Do, 104 Yale L.J. 1805 (1995).

${ }^{3}$ See, e.g., William W. Fisher III, Property and Contract on the Internet, 73 Chi.Kent L. Rev. 1203, 1217-18 (1998).

${ }^{4}$ Yochai Benkler, The Wealth of Networks: How Social Production Transforms Markets and Freedom 9 (2006).

${ }^{5}$ See generally Robert P. Merges, Locke Remixed ;-), 40 U.C. Davis L. Rev. 1259, $1260-61$ (2007).
} 
encourage "remix culture," clashes between iterative creativity and copyright are increasingly common. The rise of creativity- and communication-empowering technology has coincided with the expansion of the scope and duration of copyright protection and with new regulatory schemes designed to foster copyright-holder selfhelp. Critics have decried this increased propertization of creative works as a "second enclosure movement" that limits the ability of creative individuals to harness new technology to build upon existing cultural artifacts. ${ }^{8}$ Yochai Benkler worries, for example, that "information production could be regulated so that, for most users, it will be forced back into the industrial model, squelching the emerging model of individual, radically decentralized, and nonmarket production and its attendant improvements in freedom and justice." $" 9$

Technologically empowered individual creators are thus potential casualties of a regulatory regime that propertizes the ingredients of iterative creativity, but they are also among the beneficiaries of copyright law's largess. Copyright's statutory intricacies and subtle jurisprudence may be most accessible to corporate publishers and their lawyers, but the exclusive rights that copyright bestows are available to anyone capable of capturing creativity on a piece of paper or in a computer's memory. Individual creators are in fact increasingly harnessing copyright themselves, insisting on ownership of their rights and controlling the ways in which those

\footnotetext{
${ }^{6}$ See id. at 1262; Edward Lee, Warming Up to User-Generated Content, 2008 U. Ill. L. Rev. 1459, 1460-62 (2008); Tim Wu, Tolerated Use, 31 Colum. J.L. \& Arts 617, 619-20 (2008).

${ }^{7}$ James Boyle, The Public Domain: Enclosing the Commons of the Mind 42-53 (2008); James Boyle, The Second Enclosure Movement and the Construction of the Public Domain, 66 L. \& Contemp. Probs. 33, 37-40 (2003) [hereinafter Boyle, The Second Enclosure Movement]. But cf. Robert P. Merges, A New Dynamism in the Public Domain, 71 U. Chi. L. Rev. 183, 184 (2004) (suggesting that we ought to be "a bit less anxious about the consequences of what has been called the 'second enclosure movement," because "the increasing importance of the public domain may represent a partial self-correcting impulse in the IP system").

${ }^{8}$ See, e.g., Boyle, The Second Enclosure Movement, supra note 7, at 49; John Quiggin \& Dan Hunter, Money Ruins Everything, 30 Hastings Comm. \& Ent. L.J. 203, $246-47$ (2008).

${ }^{9}$ Benkler, supra note 4, at 26. But see Robert P. Merges, The Concept of Property in the Digital Era, 45 Hous. L. Rev. 1239, 1267 (2008) (arguing that "amateur culture in all its forms and all its myriad glories can and will thrive even in the presence of strong property rights").
} 
rights are licensed to others. Facebook users are demanding ownership of their online musings. Twitter users wonder whether their "tweets" are copyrightable. Scholars are archiving their research online and refusing to assign their copyrights to publishers. Independent musicians are streaming their own songs and operating without record companies. Organizations like the Free Software Foundation, Creative Commons, and Columbia University's Keep Your Copyrights project are encouraging individual authors to manage their copyrights in innovative ways.

When the many individual authors empowered by today's digital technology claim, retain, and manage their own copyrights, they exercise a degree of authorial autonomy befitting the Internet Age. But they simultaneously contribute to a troubling phenomenon I call "copyright atomism."

This article introduces the concept of copyright atomism and defines it along three dimensions: proliferation (how many works are subject to copyright ownership), distribution (how many different people own copyrights), and fragmentation (how many, what type, and what size of separately-owned rights exist within each copyright bundle). As proliferation, distribution, and fragmentation increase, copyright becomes more atomistic.

The consequences of atomistic copyright are suggested by a growing legal literature focused on the transaction and information costs that emerge when property entitlements are numerous, their ownership is broadly distributed, and they correspond to small or idiosyncratic resource fragments. For example, Robert Ellickson has explained how transaction costs arise in the tangible property context "from the proliferation of boundaries and ownership entities." Michael Heller's work has drawn attention to the resource

\footnotetext{
${ }^{10}$ The Merriam-Webster dictionary defines "atomism" as both "a doctrine that the physical or physical and mental universe is composed of simple indivisible minute particles" and as "individualism." Merriam-Webster's Collegiate Dictionary 78 (11th ed. 2003), available at http://www.merriam-webster.com/dictionary/atomism. By adopting it, I mean to evoke both meanings, alluding to the numerous and minute works that copyright protects, and to their ownership by far-flung individuals. The fact that "atoms" are now understood to be comprised of even smaller particles makes the terminology especially appropriate in an age in which copyrightable objects that were once considered single indivisible works are now protected as many separately copyrightable fragments. See discussion infra.

${ }^{11}$ Robert C. Ellickson, Property in Land, 102 Yale L.J. 1315, 1329 (1993).
} 
underuse that can arise when property rights fragment into an "anticommons."12 Thomas Merrill and Henry Smith focus on the information cost externalities imposed by the proliferation of customized and idiosyncratic property rights. ${ }^{13}$ Clarisa Long, ${ }^{14}$ Justin Hughes, ${ }^{15}$ Henry Smith, ${ }^{16}$ and others have applied this transaction and information cost analysis to intellectual property. In my own work, I have examined how these costs may be imposed in the intangible property context by emerging intellectual property licensing practices. ${ }^{17}$

The atomism concept contributes to this literature a novel framework for considering proliferation, distribution, and fragmentation together, drawing attention to their interactions and combined effects. The contemplation of all three dimensions reveals the unprecedented degree of atomism that characterizes the contemporary copyright environment, and the dangers this develop-

\footnotetext{
${ }^{12}$ Michael A. Heller, The Tragedy of the Anticommons: Property in the Transition from Marx to Markets, 111 Harv. L. Rev. 621, 624 (1998) ("When there are too many owners holding rights of exclusion, the resource is prone to underuse-a tragedy of the anticommons."). But cf. Robert P. Merges, Contracting Into Liability Rules: Intellectual Property Rights and Collective Rights Organizations, 84 Cal. L. Rev. 1293 (1996) (raising the possibility that strong and complicated property rights can motivate private actors to create exchange institutions that lower transaction costs that thus avoid the tragedy of the anticommons); Merges, supra note 7, at 190 (similar); F. Scott Kieff, Coordination, Property, and Intellectual Property: An Unconventional Approach to Anticompetitive Effects and Downstream Access, 56 Emory L.J. 327, 394 (2006) (similar); Lee Anne Fennell, Slices and Lumps (Mar. 22, 2008) (unpublished manuscript, available at http://ssrn.com/abstract =1106421) (describing both costs and benefits of fragmentation). On fragmentation of copyrights in particular, see Daniel Gervais, The Changing Role of Copyright Collectives, in Collective Management of Copyright and Related Rights 3, 10,12 (Daniel Gervais ed., 2006).

${ }^{13}$ Thomas W. Merrill \& Henry E. Smith, Optimal Standardization in the Law of Property: The Numerus Clausus Principle, 110 Yale L.J. 1 (2000) [hereinafter Optimal Standardization]; Thomas W. Merrill \& Henry E. Smith, The Property/Contract Interface, 101 Colum. L. Rev. 773 (2001); see also Nestor M. Davidson, Standardization and Pluralism in Property Law, 61 Vand. L. Rev. 1597 (2008) (providing a broader account of standardization of property forms).

${ }^{14}$ Clarisa Long, Information Costs in Patent and Copyright, 90 Va. L. Rev. 465 (2004).

${ }^{15}$ Justin Hughes, Size Matters (Or Should) in Copyright Law, 74 Fordham L. Rev. 575, 615-16 (2005).

${ }^{16}$ Henry E. Smith, Intellectual Property as Property: Delineating Entitlements in Information, 116 Yale L.J. 1742 (2007).

${ }^{17}$ Molly Shaffer Van Houweling, The New Servitudes, 96 Geo. L.J. 885, 932-39 (2008).
} 
ment poses. An atomistic copyright system is crowded with protected works and rights, owned by rights-holders who are numerous and far-flung, and whose preferences may be idiosyncratic. This situation can raise information and transaction costs for participants in the creative marketplace, hampering future generations of creativity and ultimately undermining the purpose of copyright-to spur the creation and dissemination of works of authorship for the ultimate benefit of the public.

Copyright atomism and its harmful consequences can be avoided or ameliorated by legal rules and by ad hoc or institutionalized private ordering in the shadow of legal rules. ${ }^{18}$ Indeed, an important literature documents how the supposed ill-effects of the "anticommons" can be avoided through voluntary transactions (and how strong property rights can encourage rather than deter such transactions). ${ }^{19}$ Counteracting atomism can come with its own costs, however. For example, atomism is reduced when ownership of copyrighted works is consolidated in the hands of publishers, employers, or other intermediaries. But this anti-atomism mechanism can deny authors autonomous control over their creations. ${ }^{20}$ Consolidation can also stifle competition, promote censorship, and make copyright distributively unfair. ${ }^{21} \mathrm{~A}$ critical question for con-

\footnotetext{
${ }^{18}$ See Robert P. Merges, Intellectual Property Rights and the New Institutional Economics, 53 Vand. L. Rev. 1857, 1865-66 (2000) (urging intellectual property scholars to apply new institutional economics to examine "[u]nder what conditions ... voluntary transactional institutions [will] take shape"); Merges, supra note 12 (documenting the emergence of institutions for voluntary exchange of intellectual property rights); Paul M. Schwartz, Property, Privacy, and Personal Data, 117 Harv. L. Rev. 2055,2110 (2004) (observing that "[i]nstitutions shape the legal and social structure in which property is necessarily embedded"); cf. Ellickson, supra note 11, at 1333 ("Because boundary locations are compromises, landowners can be expected to develop internal institutions for coordinating more fine-grained activities as well as external institutions for coordinating matters better handled on a larger territorial scale.").

${ }^{19}$ See, e.g., Merges, supra note 7; Merges, supra note 12; see also, e.g., John P. Walsh et al., Effects of Research Tool Patents and Licensing on Biomedical Innovation, in Patents in the Knowledge-Based Economy 285 (Wesley M. Cohen \& Stephen A. Merrill eds., 2003) (questioning whether thickets of patents in fact inhibit scientific research).

${ }^{20}$ See Jane C. Ginsburg, The Concept of Authorship in Comparative Copyright Law, 52 DePaul L. Rev. 1063, 1090 (2003); Comments of John M. Kernochan, 10 Colum.-VLA J.L. \& Arts 685, 690 (1986) (commenting on the Final Report of the Ad Hoc Working Group on U.S. Adherence to the Berne Convention).

${ }^{21}$ See generally Molly Shaffer Van Houweling, Distributive Values in Copyright, 83 Tex. L. Rev. 1535 (2005).
} 
temporary copyright policy is thus how to address atomism without sacrificing other values that are critical to a healthy creative environment.

This Article places the contemporary atomism dilemma in historical and doctrinal context by documenting and assessing the copyright system's previous encounters with proliferated, distributed, and fragmented ownership. Along the way, it examines how copyright law has encouraged and discouraged atomism and managed its consequences. By applying the new concept of atomism across the entire field of copyright and over centuries of experience in both Great Britain and the United States, this analysis establishes the enduring relevance of concerns about atomism within copyright policy, highlights countervailing interests, and provides a framework for thinking about how to alleviate the unfortunate contemporary consequences of atomism-and how not.

The Article proceeds in four parts. Part I presents the atomism concept along its three intersecting dimensions, illustrated with highlights from Anglo-American copyright history. Part II is a more in-depth exploration of that history, tracing atomism from medieval monasteries to the eve of the Internet era. Part III uses this history to better understand the contemporary environment, which I argue is characterized by an unprecedented degree of copyright atomism and by the failure of the mechanisms that have been deployed in the past to reduce atomism's costs. Part IV offers two preliminary ideas for addressing atomism while avoiding the pitfalls of the past.

\section{THREE DimENSIONS OF ATOMISM}

I use the term "atomism" (and its opposite, "holism") to describe the combined effect of three different but intersecting features of the copyright system: (1) how many works are subject to copyright ownership (proliferation); (2) how many different people own copyrights (distribution); and (3) how many, what type, and what size of separately-owned rights exist within each copyright bundle (fragmentation). Copyright becomes more atomistic as proliferation, distribution, and fragmentation increase. Countervailing developments that result in more holistic copyright include subject matter limitations and prerequisites (versus proliferation), ownership consolidation (versus distribution), and unification and stan- 
dardization (versus fragmentation) of the rights attached to each protected work.

In an atomistic copyright system, participants in the creative marketplace may have to track down and negotiate with many farflung rights holders regarding many separate rights. Valuable uses of copyrighted works may therefore be prohibitively difficult or expensive. ${ }^{22}$ But holistic (limited, consolidated, and unified) copyright has its own disadvantages. Foremost among these is the way in which holistic copyright can constrain the autonomy of individual authors, who may prefer (at least where their own creations are concerned) to have more rights that they can exercise independently, trading in customized bundles of fragmented sticks. ${ }^{23}$ Relatedly, holistic copyright may limit competition, diversity of expression, and distributive fairness if the marketplace is dominated by holders of a few consolidated and unified bundles of rights.

Over time, the U.S. copyright system has tended generally toward greater atomism. This is easiest to see on the dimension of proliferation, where formal eligibility requirements (registration and the like) have been eliminated and the subject matter of copyright has expanded along with the rise of new forms of creativity (photography, motion pictures, computer software, etc.). Policy makers and participants in the copyright system have at times been attentive to the costs imposed by atomization, however, and proliferation has therefore coincided with occasional countervailing moves toward holism on other dimensions. Consider, for example, the development in the late nineteenth and early twentieth centuries of the work-for-hire doctrine, which created the legal fiction that consolidating employers (instead of distributed individual employees) are the authors and therefore the owners of works created in their employ. While copyrights continued to proliferate in this period, the work-for-hire doctrine limited the distribution of those copyrights and thus counteracted some of the atomizing effects of proliferation. Although many copyrighted works were created, it

\footnotetext{
${ }^{22}$ See U.S. Copyright Office, Report on Orphan Works 3 (2006), available at http://www.copyright.gov/orphan/orphan-report.pdf; William M. Landes \& Richard A. Posner, Indefinitely Renewable Copyright, 70 U. Chi. L. Rev. 471, 477 (2003) (describing the tracing costs involved in identifying the copyright holders of old works).

${ }^{23} \mathrm{Cf}$. Davidson, supra note 13 , at $1622-23$ (noting the tension between property standardization and property-owner autonomy).
} 
was no longer necessary to seek permission from every individual creator in order to exploit them.

As this example illustrates, copyright atomism and its consequences can only be accurately assessed by considering the combined effect of and interactions between developments along every dimension of atomism. But before taking on that task, I will expand briefly on the three dimensions of atomism with additional examples drawn from the history of Anglo-American copyright.

\section{A. Proliferation}

This dimension of atomism refers to the number of works that are subject to copyright ownership. More protected works means more proliferation, and more proliferation means more atomism. By contrast, limits on copyrightable subject matter and technical prerequisites that result in the exclusion of some protectable works make copyright relatively holistic.

Change on the proliferation dimension can result from changes in the legal definition of copyrightable subject matter. For example, U.S. copyright was initially limited to books, charts, maps, and analogous printed material. Copyright proliferated with the addition of new categories of protectable subject matter (e.g., musical compositions, photographs, motion pictures, sound recordings, computer software, etc.). Ownership proliferated even more significantly when a series of changes, starting with the Copyright Act of 1976, removed the technical prerequisites for acquiring copyrights (registration, notice, and other formalities). Copyright now applies automatically to every fixed and original work that falls within its expansive subject matter.

Change on this dimension can also result from changes in the creative environment. For example, the number of copyrighted works grew along with the growth of the U.S. publishing industry during the nineteenth century, although the formality requirements that still existed meant that not every new work was protected. More dramatically, today's digital technology is producing an explosion of creativity; and because copyright is now automatic, this technological change is also producing massive proliferation in the number of copyrighted works. 
Highlights of Proliferation-Related Developments

Expansion of protectable subject matter, e.g., to musical compositions in 1831, photographs in 1865 , motion pictures in 1912, sound recordings in 1971, and any "work of authorship" in 1976

Automatic protection afforded by 1976-1992 statutory changes removing mandatory formalities

Increased creative output, e.g., 19th-century publishing, 21st-century user-generated content

\section{B. Distribution}

This dimension of atomism refers to the number of different people or entities who qualify as copyright owners. Copyright ownership can be consolidated among a limited pool of eligible owners or distributed among many different people; more owners means more people from whom to seek permission before engaging in activities (operating a radio station, for example) that implicate many copyrights. Highly distributed ownership makes copyright relatively atomistic while highly consolidated ownership makes copyright relatively holistic.

Change on the distribution dimension can result from changes in the legal allocation of initial copyrights. For example, both the first U.S. Copyright Act of 1790 and its predecessor, the British Statute of Anne, distributed initial ownership of copyrights to individual authors, abandoning the previous English practice of consolidating ownership in the members of the exclusive Stationers' Company of publishers and booksellers. Subsequent amendments to the U.S. Copyright Act have retained the initial allocation of ownership to authors. But, as noted above, the work-for-hire doctrine codified in the 1909 Act sometimes deems employers and other corporate entities to be the authors of works prepared by individual people, thus consolidating initial copyright ownership as a matter of law. 
The degree of consolidation of copyright ownership is also a function of legal rules governing alienability of copyrights. For example, under the Stationers' Company scheme, exclusive rights were both initially assigned to stationers and generally could only be transferred to other members of the guild, thus maintaining consolidated ownership. By contrast, the Statute of Anne and the Copyright Act of 1790 both permitted transfer of copyrights to anyone, expanding the potential distribution beyond the universe of authors who were eligible for initial ownership (although the practical effect was different, as we will see in a moment). Free alienability-and thus the potential for distribution of copyright ownership to anyone in the world-remains a feature of contemporary copyright, but the Copyright Act of 1976 imposed a new formal limitation on transfers with its written instrument requirement.

Legal rules about initial ownership and transferability can thus contribute to consolidation or distribution of ownership, but ultimately the degree of consolidation and/or distribution depends on private ordering in the shadow of those rules. For example, although both the British Statute of Anne and the U.S. Copyright Act of 1790 allocated initial ownership to authors and allowed subsequent transfer to anyone, the continued market power of the Stationers' Company meant that British authors who wanted their books to be published had little choice but to assign their copyrights to the same publishers in whom ownership had been consolidated in the previous era; the internal institutional practices and norms of the Stationers' Company limited subsequent transactions. In the United States, assignments from authors to publishers also had the effect of reconsolidating ownership, but to a lesser extent because the publishing industry was more competitive. Today, authors still often assign their copyrights to publishers and other consolidating intermediaries. Indeed, institutions like the American Society of Composers, Authors and Publishers ("ASCAP") have as their primary purpose consolidating copyright ownership (or at least control) in order to overcome the complications associated with broad distribution. But as technology puts the tools of publishing at the fingertips of anyone with a computer and Internet access, authors are increasingly retaining ownership and control of copyrights in their own atomistic hands. 
Highlights of Distribution-Related Developments

Initial copyright allocated to authors instead of publishers in Statute of Anne and 1790 Copyright Act

18th- and 19th-century assignment practices reconsolidated ownership in publishers in Great Britain and (to a lesser extent) the United States; 20thcentury institutions like ASCAP exercised consolidated control

1909 codification of work-for-hire doctrine allocated some initial ownership to employers and consigning parties instead of to individual authors

Digital age technology allows more authors to create and publish independently and to retain their copyrights

\section{Fragmentation}

In contrast to distribution, which refers to the number of owners in the copyright system as a whole, fragmentation refers to the number of people to whom ownership of any single creative artifact and the work of authorship embedded in it can be divided (and thus, importantly, the number of people from whom permission must be sought before others can exploit the work). To put it another way, this dimension of atomism refers to how many (and also what size and what different types of) separately owned rights exist within each copyright bundle. Fragmented ownership makes copyright relatively atomistic while unified ownership makes copyright relatively holistic.

At the holistic extreme, only the person in lawful possession of the tangible object (a book, for example) on which the intangible work (the story told on its pages) is embedded can control exploi- 
tation of the work. Under such a scheme, an author could prevent copying of her novel by maintaining possession of the manuscript. The law in operation here is not really the law of copyright at all, but simply the law of personal property as applied to artifacts of creativity. This "proto-copyright" governed in England until the Crown began to grant monopoly printing privileges (initially to individual printers, later to the Stationers' Company) in the sixteenth century-privileges that were linked to, but separable from, ownership of physical manuscripts.

The Stationers' Company regime thus caused a change on the fragmentation dimension by introducing fragmentation between the tangible object and the intangible right to publish its contents. The Statute of Anne and the Copyright Act of 1790 followed suit. This basic fragmentation persists: I own the books on my bookshelf but not their copyrights. Over time, however, there have been marginal adjustments to the relationship between chattel ownership and copyright ownership. For example, the Copyright Act of 1909 codified the judicially-developed first sale doctrine, which gives lawful owners of tangible copies the right to distribute and display those copies publicly (rights that are otherwise among the exclusive intangible rights of the copyright holder). First sale thus unifies chattel ownership with some of the sticks in the bundle of intangible copyright. More recently, the unifying potential of the doctrine has been eroded to some extent by copyright holder attempts to re-fragment rights through private ordering.

Beyond the basic fragmentation of tangible and intangible ownership, intangible rights can themselves be further fragmented between multiple owners. Fragmentation of intangible rights is partly a function of how the law deals with transfers of existing copyrights to multiple people (through assignment, bequest, or inheritance). It is also a function of how the law allocates initial ownership in situations where multiple people have contributed to a single work; for example, where a lyricist and composer work together on a song, where a writer's story is adapted for a movie, or where an editor combines multiple contributions into an anthology. As I explain in detail below, the relationship between these authors is governed by statutory and judge-made rules about "joint works," "collective works," and "derivative works." Fragmentation has ebbed and flowed with adjustments to these rules. For example, the joint au- 
thorship doctrine in U.S. law developed in the early twentieth century largely in the context of musical works to which both a lyricist and composer had contributed. The judge-made doctrine provided that where multiple authors had worked "in furtherance of a common design," the default rule was that each had undivided rights to exploit the entire work (a relationship analogized to a tenancy in common in real property law). Although this rule granted ownership rights to multiple people, it was less fragmenting as a practical matter than granting exclusive rights in the lyrics to one person and rights to the music to another, such that no one has the rights necessary unilaterally to exploit the entire combined work or to authorize others to do so. The rule of undivided co-ownership for joint works persists; but, as I explain below, its scope has changed along with shifting definitions of who qualifies as a joint author.

Note that the work-for-hire doctrine also has a role to play in modulating fragmentation. I described it above as a consolidating doctrine because it makes an employer the owner of many separate works prepared by individual employees (e.g., photographs taken by employees of a stock-photography company). But it can also operate to unify ownership where multiple employees have labored together on a single work (e.g., a crew working on a movie), or on components that might both stand on their own and be combined into a larger work (e.g., encyclopedia entries or newspaper articles).

The idea that encyclopedias are both works and collections of smaller works suggests yet another aspect of fragmentation: the size of the intangible objects to which protection attaches. If smaller creative fragments are considered "works" eligible for copyright, then more people can claim the status of author/owner and object to even seemingly de minimis borrowing. As Justin Hughes has observed, contemporary copyright increasingly protects "microworks," with just these consequences. ${ }^{24}$ Consider what this means for a collaborative project like Wikipedia, to which millions of people have contributed, some of them adding only a few words or editorial changes. If each of these contributions is considered an individual work, then copying even a portion of a Wikipedia entry will implicate multiple copyrights and potentially require

\footnotetext{
${ }^{24}$ Hughes, supra note 15 , at 575 .
} 
multiple negotiations. (As it turns out, the public licensing scheme adopted for Wikipedia solves this problem in some cases, as I discuss below.)

Fragmentation is a function not only of the initial allocation and size of the rights divided among multiple potential claimants, but also of subsequent transfers. The fragmenting effect of such transfers depends in part on rules governing whether a single copyright can be divided into separate rights to exploit the work in different ways. For example, the U.S. Copyright Act of 1909 granted authors multiple exclusive rights-to copy, adapt, perform, etc. But under the "indivisibility" doctrine, courts interpreted the Act to forbid assignment of any of these rights individually. The copyright had to be assigned as a unified bundle or not at all. The Copyright Act of 1976 expressly abandoned indivisibility, providing that the exclusive rights could be divided and owned separately in fragmented sticks. In practice, fine-grained division of copyrights has become more common with the growth of new technologies for exploiting single copyrighted works in multiple ways. Moreover, copyright owners are adopting innovative ways of transferring and licensing their copyrights, making fragments idiosyncratic (and sometimes incompatible) as well as numerous.

A final aspect of fragmentation is temporal: whether there can be both present and future interest holders of a given intangible right. ${ }^{25}$ The Statute of Anne and the Copyright Act of 1790 built temporal fragmentation into the law by granting initial and renewal terms, which could be separately transferred so as to create both present and future interests held by different people. In practice, however, combined transfers of both the initial and renewal terms (typically from an author to a publisher) often resulted in unified ownership by a single assignee. The 1976 Act eliminated the dualterm system but re-injected a different mechanism for temporal fragmentation by creating a non-waivable termination of transfer right that allows authors or their statutory heirs to reclaim transferred copyrights decades later.

\footnotetext{
${ }^{25} \mathrm{Cf}$. Ellickson, supra note 11 , at 1364 (observing that "[t]emporal transitions in land ownership invariably entail either transaction costs or deadweight losses").
} 
Highlights of Fragmentation-Related Developments

\begin{tabular}{|l|l|}
\hline $\begin{array}{l}\text { Stationers' Company regime separates tangible and } \\
\text { intangible rights }\end{array}$ & \\
\hline First sale doctrine codified in 1909 & \\
\hline $\begin{array}{l}\text { Undivided ownership by joint authors established in } \\
\text { early 20th-century case law }\end{array}$ & \\
\hline 1976 Act eliminates indivisibility doctrine & \\
\hline $\begin{array}{l}\text { Temporal fragmentation introduced by dual terms in } \\
\text { Statute of Anne and 1790 Act and reinforced by } \\
\text { termination of transfer alternative in 1976 }\end{array}$ \\
\hline $\begin{array}{l}\text { Contemporary recognition of "microworks" and } \\
\text { idiosyncratic copyright bundles }\end{array}$ \\
\hline
\end{tabular}

\section{Atomism Across Multiple Dimensions}

The historical highlights just surveyed help to illustrate the three dimensions of atomism. But an accurate assessment of atomism and its effects cannot focus on any one dimension in isolation. So, in the following Sections, I examine proliferation, distribution, and fragmentation (and countervailing holistic developments) as they have combined and interacted during several different eras in Anglo-American copyright law. My goal is to pinpoint and examine episodes that generate insights about today's relatively atomistic copyright environment and about how we might mitigate the costs 
of atomism without unduly sacrificing authorial autonomy and other important copyright values.

\section{Atomism in Historical Perspective}

\section{A. The Pre-Modern Era: Proto-Copyright and the Stationers' Company}

Before the emergence of copyright as we now understand it, as the intangible right to control reproduction and certain other uses of works of authorship, a much more limited form of control was available to owners of manuscripts who could limit access to (and thus copying of) books. ${ }^{26}$ For example, it was common during the Middle Ages for monasteries to charge fees for permission to copy manuscripts in their collections. ${ }^{27}$ As literary historian Mark Rose observes, "this practice might be thought to imply a form of copyright, and yet the bookowner's property was not a right in the text as such but in the manuscript as a physical object made of ink and parchment." ${ }^{28}$ Thus, once a manuscript was copied, its owner lost control of the text embodied in it. This proto-copyright was valuable, however, in an age before mechanical reproduction, when an owner could charge a premium based on the superior quality of his manuscript compared to error-ridden copies. ${ }^{29}$

It is difficult even to apply notions of proliferation and distribution to this proto-copyright scheme because it lacked the fragmentation that is the essence of copyright: fragmentation between the right to possess a book and the right to exploit its intellectual content. Ownership of the book was unified with ownership of the

${ }^{26}$ Cf. Wheaton v. Peters, 33 U.S. 591, 657 (1834) ("That an author, at common law, has a property in his manuscript, and may obtain redress against any one who deprives him of it ... cannot be doubted.").

${ }^{27} 2$ George Haven Putnam, Books and Their Makers During the Middle Ages 485 (1897); Mark Rose, Authors and Owners: The Invention of Copyright 9 (1995); cf. Jane C. Ginsburg, "Une Chose Publique"? The Author's Domain and the Public Domain in Early British, French and US Copyright Law, 65 Cambridge L.J. 636, 639 (2006) ("[S]ome monasteries resorted to a kind of technological measure to prevent unauthorised access and copying: they chained the books to the walls.").

${ }^{28}$ Rose, supra note 27 , at 9.

${ }^{29}$ See Putnam, supra note 27, at 482-84 (describing how monasteries "came to understand that gain could be secured for their monastery chest by conceding for pay the privilege of making one or more copies of their codex"). 
work. There were no separate intangible rights that could proliferate and be widely distributed. ${ }^{30}$

This crude system of proto-copyright befitted the Middle Ages, when literacy rates were low and reproduction of books was laborious, rare, and imperfect. ${ }^{31}$ But the invention and spread of the printing press in Europe in the second half of the fifteenth century dramatically expanded the potential market for copies of books. ${ }^{32}$ Holistic proto-copyright was not very useful to the new commercial printers who wanted to exploit this market by releasing multiple copies of books to the public instead of guarding them in monasteries. $^{33}$

In the fifteenth and sixteenth centuries, European governments obliged the emerging printing industry by granting individual printers exclusive privileges to print specified books or classes of books. ${ }^{34}$ These privileges insulated their recipients from competition even after the printers had distributed physical copies of the covered books. They are thus aptly characterized as "the earliest genuine anticipations of copyright.'

The English Crown began to grant such privileges (in the form of "letters patent") in the early sixteenth century for specified books and classes of books, but most printing remained outside the scope of these initial patents. ${ }^{36}$ Control over the growing printing trade became much more comprehensive because of several events in the late 1550s. In 1557, Queen Mary and King Phillip granted a charter to the Stationers' Company, the guild into which members

\footnotetext{
${ }^{30}$ And of course books themselves did not easily proliferate, and their ownership was not widely distributed before the advent of the printing press.

${ }^{31}$ See Ginsburg, supra note 27, at 638.

${ }^{32}$ See generally Elizabeth L. Eisenstein, The Printing Revolution in Early Modern Europe (2d ed. 2005).

${ }^{33}$ See Putnam, supra note 27 , at 485 ; Rose, supra note 27 , at 9 . See generally Augustine Birrell, Seven Lectures on the Law and History of Copyright in Books 55 (1899); John Feather, Publishing, Piracy and Politics: An Historical Study of Copyright in Britain 10 (1994).

${ }^{34}$ Rose, supra note 27 , at 12 .

${ }^{35}$ Id. at 12; see also Pamela Samuelson, Copyright and Freedom of Expression in Historical Perspective, 10 J. Intell. Prop. L. 319, 323 (2003).

${ }^{36}$ See Feather, supra note 33, at 11; see also Lyman Ray Patterson, Copyright in Historical Perspective 42 (1968).
} 
of the London book trade had first organized themselves in $1403 .^{37}$ The 1557 charter forbade printing by anyone other than Stationers' Company members (and those lucky few with letters patent from the Crown). ${ }^{38}$ In 1559 , Queen Elizabeth both confirmed the Stationers' Company charter and imposed a regime of censorship under which all books were to be licensed by royal censors, with the Stationers' Company enlisted to help enforce the licensing requirement. ${ }^{39}$ A series of Star Chamber Decrees and parliamentary Licensing Acts would reinforce Queen Elizabeth's injunction over the course of the next century. ${ }^{40}$

The Stationers' Company in turn adopted internal rules for distributing to its members the exclusive rights (referred to as "copies") to publish individual books, for recording those copies in the Company's Register, and for punishing members who printed books for which they had not registered their copies. ${ }^{41}$ These internal company rules were enforced and disputes between members were heard by the officers of the company (the "master" and his deputies or "wardens") and its "Court of Assistants."

As an episode in Anglo-American copyright history, the Stationers' Company regime (and the system of letters patent with which it overlapped) is notable for introducing fragmentation between intangible rights to publish and tangible rights to possess manuscripts. The available evidence suggests that the exclusive rights the Company bestowed upon individual members were initially tied to physical manuscript ownership: members registered with the Company the titles of manuscripts that they owned (and

\footnotetext{
${ }^{37}$ See generally 4 The Cambridge History of English and American Literature, ch. XVIII, \&1 (A.W. Ward \& W.R. Waller eds., 1933), available at http://bartleby.com/ 214/1801.html [hereinafter Cambridge History].

${ }^{38}$ Royal Charter of the Company of Stationers (1557), reprinted in 1 A Transcript of the Registers of the Company of Stationers of London xxx-xxxi (Edward Arber ed., 1950), available at http://www.copyrighthistory.org/cgibin/kleioc/0010/exec/ausgabe/\% 22uk_1557\%22; see also Cambridge History, supra note 37, at ch. XVIII, $\$ 2$, available at http://bartleby.com/214/1802.html.

On the relationship between letters patent and the Stationers' Company, see Patterson, supra note 36, at 5-6; Feather, supra note 33, at 20.

${ }^{39}$ See Feather, supra note 33, at 15.

${ }^{40}$ See Patterson, supra note 36 , at $46-47$ \& n.14; Harry Ransom, The First Copyright Statute 5 (1956).

${ }^{41}$ See Birrell, supra note 33, at 73; Patterson, supra note 36, at 43-44.

${ }^{42}$ See Patterson, supra note 36 , at $32-35$.
} 
for which they at least sometimes had paid authors) ${ }^{43}$ But registration thenceforth served as evidence of ownership of an exclusive intangible property right independent of any physical object. These were non-possessory rights to intangible works-rights that could be separated such that ownership of a manuscript and ownership of the exclusive right to publish it could be held by different people. This was fragmentation of the most basic sort: the cleavage of tangible and intangible ownership that is now considered the essence of copyright.

With the creation of intangible rights, it becomes possible to characterize those rights on the other dimensions of proliferation and distribution, and to consider degrees of fragmentation beyond the most basic separation of tangible and intangible rights.

\section{Proliferation: How Many Works Are Subject to Ownership?}

English letters patent awarded printing rights to specific works or classes of works. Their coverage became broad but was never comprehensive. For example, by the mid-1570s there were privileges covering all documents issued by the Crown and a variety of other important categories, including bibles and school books. ${ }^{44}$ But the majority of works remained outside the coverage of these classes. ${ }^{45}$ Furthermore, the privileges were typically time-limited such that works eventually escaped their reach. ${ }^{46}$

The Stationers' Company monopoly, by contrast, extended to nearly everything printed ${ }^{47}$ and was understood to be perpet-

\footnotetext{
${ }^{43}$ Patterson, supra note 36 , at 52 ; see also Birrell, supra note 33 , at 82 ; Benjamin Kaplan, An Unhurried View of Copyright 5 (1967).

${ }^{4}$ Feather, supra note 33, at 12.

${ }^{45}$ Id. at 14.

${ }^{46}$ But see H. Tomás Gómez-Arostegui, What History Teaches Us About Copyright Injunctions and the Inadequate-Remedy-at-Law Requirement, $81 \mathrm{~S}$. Cal. L. Rev. 1197,1215 (2008) (identifying one important patent that, "[u]nlike most other printing patents," was perpetual).

${ }^{47}$ The Charter refers to printing of books or "any thing." Royal Charter of the Company of Stationers, supra note 38, at xxx-xxxi; see also Patterson, supra note 36 , at 9 ("Works subject to copyright included not only writings, but also maps, portraits, official forms, and even statutes."); id. at 55 ("[W]hile books, ballads and pamphlets constitute the great majority of copyrighted works, there are also entries for maps, pictures, bills of lading, and various legal forms, as well as statutes."). The monopoly was qualified only by its co-existence with some royal printing patents held by nonstationers. See id. at 5-6. On the (perhaps underappreciated) role of these co-existing
} 
ual. ${ }^{48}$ Even under the more comprehensive system of ownership established by the Stationers' Company, however, there were limits on what was protected as a practical matter. The Company's rules required its members to enter their claims in its Register. Although most scholars of the period have concluded that entry in the Register was neither necessary nor sufficient to establish ownership, it did serve as proof of ownership, and " $[t]$ he absence of an entry in the Register could be fatal to any claim about the ownership of a copy." ${ }^{\$ 0}$ This registration requirement thus foreshadows later copyright registration systems, discussed below, that effectively limited proliferation by making registration a prerequisite for protection (and releasing published but unregistered works into the public domain). The effect of non-registration was likely less dramatic during the Stationers' Company era. Rights to an unregistered work might have been unenforceable by any individual stationer, but his competitors would themselves have been subject to the hurdles of the registration and licensing requirements before they could print such a work. In essence then, every printed work was subject to Stationers' Company control in one way or another. ${ }^{51}$

\section{Distribution: How Many People Own Rights?}

The control that the Stationers' Company exercised over the English book trade manifested itself in individual rights that the Company allocated to Company members. But distribution was limited to this exclusive guild-a group that numbered only ninetyseven when the charter was issued in $1557^{52}$ and whose growth was

patents, see Arnold Hunt, Book Trade Patents, 1603-1640, in The Book Trade \& its Customers 1450-1900, at 27-39 (Arnold Hunt et al. eds., 1997).

${ }^{48}$ Patterson, supra note 36 , at 5 ; see also id. at 13 (noting that copyright under the Statute of Anne, unlike Stationers' copyright, "was not to exist in perpetuity").

${ }^{49}$ See, e.g., Feather, supra note 33 , at $25-27$; Patterson, supra note 36 , at 51; see also id. at 55-64 (describing the evolution of the registration requirement); Putnam, supra note 27, at 468 ("These Stationers' Hall entries were in certain respects similar to the records in the Land Office of a western Territory or in the County Clerk's office of a State, records which serve as final evidence of the title or ownership of the lands specified.").

${ }^{50}$ Feather, supra note 33, at 26.

${ }^{51}$ With the exceptions noted in supra note 47.

${ }^{52}$ Royal Charter of the Company of Stationers, supra note 38, at xxviii; see also Cambridge History, supra note 37 , at ch. XVIII, $\S 1$, available at http://bartleby.com/ 214/1801.html. By 1577 there were twenty-two printing houses in London and 175 
controlled by a strict system of apprenticeship and promotion. ${ }^{53}$ Rights held by Company members were frequently transferred and bequeathed ${ }^{54}$ but only to other members of the Company (with rare exceptions). ${ }^{5 s}$ If a member died without having bequeathed his rights to a fellow member, they were not distributed among his heirs but instead reverted to the Company (which might in turn give them to his widow but only for her lifetime). ${ }^{56}$

\section{Fragmentation: Among How Many People Is Each Work Divided?}

During this era the intangible right to print copies of a given book was subject to ownership by multiple people..$^{57}$ Thus, beyond the basic fragmentation of tangible from intangible ownership discussed above, the intangible right to print could itself be further fragmented among co-owners. ${ }^{58}$ Consider, for example, this 1641 entry in the Register, recording a transfer of a one-half interest in a copy from one stationer to two transferees, Robert Somers and Thomas Cowley: "Assigned over unto them by Stephen Bulkeley, by vertue of a note under the hand and seale of the said Stephen, one full moyety or halfe of his copie called The Masse in Latyn \& English ...."

As such fractional interests were transferred and retransferred, the ownership of the rights to a single work could get more and

\footnotetext{
"printers and stationers, journeymen and all." Id. at ch. XVIII, 8 , available at http://bartleby.com /214/1806.html.

${ }^{53}$ See Cambridge History, supra note 37 at ch. XVIII, §6, available at http://bartleby.com /214/1806.html; Patterson, supra note 36, at 33.

${ }^{54}$ Patterson, supra note 36 , at 5; Rose, supra note 27 , at 12.

${ }^{55}$ See, e.g., Birrell, supra note 33, at 73; Patterson, supra note 36, at 9, 47. For discussions of rare exceptions, see Adrian Johns, The Nature of the Book 229 \& n.124 (1998); Feather, supra note 33, at 25-26.

${ }^{56}$ See Patterson, supra note 36 , at 47 . The Company practice was to grant a life interest to members' widows. Id. at 48.

${ }^{57}$ Id. at 9 ; Rose, supra note 27 , at 12.

${ }^{58}$ See generally Feather, supra note 33 , at 42 .

${ }^{59} 1$ A Transcript of the Registers of the Worshipful Company of Stationers 23 (G.E. Briscoe Eyre, C.R. Rivington \& H.R. Plomer eds., 1913) [hereinafter Copyright Registers] (entry of May 15, 1641).
} 
more complex ${ }^{60}$ as this 1645 entry creating two one-eighth interests in a single work reveals:

Entred ... by vertue of an assignment under the hand \& seale of John Rothwell . . the moyety or halfe of the said John Rothwell's right \& Interest in the booke called An Exposicon upon the $4^{\text {th }} 5^{\text {th }} 6^{\text {th }} \& 7^{\text {th }}$ chapters of JOB, by $\mathrm{M}^{\mathrm{T}}$ Carill, the said $\mathrm{M}^{\mathrm{r}}$ Rothwells right therein being a fourth pte, of $\mathrm{w}^{\text {ch }}$ the said $\mathrm{M}^{\mathrm{r}}$ Crooke is to have one halfe pte thereof .....

This John Rothwell, who had served as Warden of the Company in 1634 and $1638,{ }^{62}$ appears to have been an especially active trader in fractional rights. In 1651 he assigned all his rights to " $\mathrm{M}^{\mathrm{r}}$ Carrills workes upon JOB," which by that point amounted to "[a] third pte in the first pte, an eighth pte in $y^{e}$ second pte, an eighth pte in the third pte, and a fourth pte in ye fourth pte thereof."

What was the practical effect of such finely fragmented ownership of a single work? The 1681 Company Ordinance forbade printing "without the licence or consent of such member or members" in whose name a book was registered, suggesting that where a work was entered in the name of multiple stationers, permission from each of them was necessary for the book to be printed. ${ }^{64}$

In theory, rules requiring permission from each of several members for whom a copy was registered, combined with the division of copies into halves, fourths, eighths, etc., could have made it difficult to trace ownership and assemble the permissions necessary to print a co-owned book. Indeed, there are accounts of some dis-

\footnotetext{
${ }^{60}$ See, e.g., Giles Mandelbrote, Richard Bentley's Copies: The Ownership of Copyrights in the Late 17th Century, in The Book Trade \& its Customers 1450-1900, supra note 47 , at 55,61, 64 (documenting the many fractional shares, some "as small as a twenty-fourth and a forty-eighth," held by bookseller Richard Bentley and observing that "[s]ome of them had been in the book trade since the 16th century: the more hands they had passed through, the smaller the fraction was likely to have become").

${ }^{61}$ Copyright Registers, supra note 59, at 221 (entry of Mar. 17, 1645).

${ }^{62}$ Henry R. Plomer, A Dictionary of the Booksellers and Printers Who Were at Work in England, Scotland and Ireiand from 1641 to 1667, at 157 (1907).

${ }^{63}$ Copyright Registers, supra note 59, at 384 (entry of Nov. 24, 1651).

${ }^{64}$ Stationers' Company Ordinance of 1681 , reprinted in Birrell, supra note 33, at 7980 ; see also id. at 80-81 (reprinting Ordinance of 1694, which includes identical language). But cf. Cyprian Blagden, The Stationers' Company: A History, 1403-1959, at 42 (1960) (quoting the Ordinance of 1583 , which does not refer to multiple owners).
} 
putes and confusion regarding fragmented rights. ${ }^{65}$ But scanning the Register suggests two reasons such disputes may have been limited. First, the Register itself served as a useful (though imperfect $^{66}$ ) tool for identifying copy-holders and their respective rights. Second, the community of stationers whose dealings are recorded in the Register was a small and insular one. The same names appear again and again as entrants (and the entrants are also often among the officials in charge of making the entries). Ownership was thus fragmented but familiar, ${ }^{67}$ divided among a small group of potential owners (initially, recall, just ninety-seven men) who often entered into their complicated ownership arrangements with plans already in mind about whom they would authorize to print their works and how the profits would be divided ${ }^{68}$ Indeed, entries in the Register often documented such ex ante arrangements. For example, a printer might assign a copyright to a fellow stationer (or stationers) with the express provision that the printer would subsequently be employed to do the printing. ${ }^{69}$

\footnotetext{
${ }^{65}$ See, e.g., Mandelbrote, supra note 60 , at $55,62,66$. I have not conducted an exhaustive search of the primary sources to determine the frequency of such disputes. Valuable guidance for future research on this question is provided in GómezArostegui, supra note 46 , at 1256 n. 326 .

${ }^{66}$ See, e.g., Mandelbrote, supra note 60 , at 55, 68 (observing that "[b]y the late 17 th century the Stationers' Company's system for registering the ownership of copies was becoming discredited" and that "[t] hey had not been designed to cope with repeat entries of different shares of the same copy, in smaller and smaller fractions").

${ }^{67}$ Cf. Robert C. Ellickson, A Hypothesis of Wealth-Maximizing Norms: Evidence from the Whaling Industry, 5 J.L. Econ. \& Org. 83, 93-94 (1989) (observing consequences for property norms of "close-knit social conditions"); Ellickson, supra note 11, at 1320-21, 1331-32 (describing the development of efficient individual ownership rules in close-knit groups); Henry E. Smith, The Language of Property: Form, Context, and Audience, 55 Stan. L. Rev. 1105, 1125 (2003) ("The communication of legal relations is subject to a tradeoff between intensiveness and extensiveness of information: For the same cost, one can communicate a lot to a small, close-knit audience or a little to a large, anonymous audience.").

${ }^{68}$ See generally Patterson, supra note 36 , at 46 .

${ }^{69}$ See, for example, this September 16, 1643 entry:

Assigned over unto [Master Crooke] by vertue of a note under the hand \& seale of James Young all the estate, right title and interest wch he the said James Young hath of $\&$ in the full Moyety or one halfe of the copie called, $A$ large \& compleat Concordance to the Bible. . . . Provided that the said James Young is to have the workemanship of printing the same from tyme to tyme....

Copyright Registers, supra note 59, at 75 (entry of Sept. 16, 1643).
} 
There were some instances in which ownership was so fragmented among multiple stationers that co-management might have been unwieldy and was consequently replaced with unified management by the Company itself. This was the case for what came to be known as the "English Stock," important printing patents that were co-owned by a group of shareholding members of the Company. ${ }^{70}$ Historian John Feather explains that "to avoid disputes between the shareholders, its management was effectively delegated to the Court of Assistants, the governing body of the Stationers' Company." ${ }^{71}$ Shareholders received dividends but did not have an active role in managing the portfolio; thus ownership was technically fragmented but control was unified. ${ }^{72}$

\section{Atomism Across Multiple Dimensions}

The era of the Stationers' Company regime (and the system of letters patent with which it overlapped) was the first time in the history of Anglo-American copyright in which intangible rights to exploit works of authorship were clearly conceived of as separate from chattel ownership. It thus offers the first historical episode in which we can characterize those rights along all three dimensions of atomism and set a baseline to which to compare subsequent eras.

\footnotetext{
${ }^{70}$ John Feather, From Rights in Copies to Copyright: The Recognition of Authors' Rights in English Law and Practice in the Sixteenth and Seventeenth Centuries, 10 Cardozo Arts \& Ent. L.J. 455, 464 (1992) (explaining that the English Stock began as "a complex piece of jointly-owned property" in "schoolbook and other patents"). See generally Cyprian Blagden, The English Stock of the Stationers' Company in the Time of the Stuarts, 12 The Libr. 167 (5th Ser. 1957); Cyprian Blagden, The English Stock of the Stationers' Company: An Account of its Origins, 10 The Libr. 163 (5th Ser. 1955).

${ }^{71}$ Feather, supra note 70, at 464 ; see also Blagden, The English Stock of the Stationers' Company in the Time of the Stuarts, supra note 70, at 170; Patterson, supra note 36, at 110; Gómez-Arostegui, supra note 46, at 1215.

${ }^{\text {'n }}$ But cf. Blagden, The English Stock of the Stationers' Company in the Time of the Stuarts, supra note 70 , at 178 (observing that "the relationship between the government of the Company and that important group of its members who made up the partners in the English Stock was full of difficulties-and of causes of confusion even in the seventeenth century," and "[t]he borderline between Company affairs and Stock affairs, between Company income and Stock income, between Company property and Stock property, was always wavy and at times indistinguishable even to the officials involved." (citation omitted)).
} 
In some respects, the copyright landscape established in the era of the Stationers' Company monopoly was quite atomistic. As to proliferation, every type of printed work was subject to the Company's perpetual rights. As to distribution, the Company parceled out rights to individual members instead of maintaining consolidated ownership of them. Finally, as to fragmentation, the rights were not only separate from tangible rights to physical manuscripts, but were also themselves capable of fragmentation among multiple co-owners.

Notwithstanding these apparently atomistic features, the Stationers' Company regime was fundamentally holistic on account of its defining characteristics: the small and closed membership of the Company itself and its members' exclusive ability to have their rights recorded in the Register and enforced against others. Regardless of how many rights there were and how amenable they were to distribution and fragmentation, the pool of rights holders was limited and identifiable. Indeed, the entire point of the regime from the stationers' perspective was to maintain their collective monopoly over the book trade. This interest coincided with the Crown's interest in creating a publishing bottleneck that facilitated censorship - censorship that of course limited the universe of works to which atomistic rights could apply. ${ }^{73}$

The fundamental holism of the Stationers' Company regime meant that it was not plagued with the information and transaction cost problems I associate with atomism. If one stationer wanted to print a book to which another had the rights, ${ }^{74}$ he could identify the owner by consulting the Register. ${ }^{75}$ The person so identified would be one of a limited group of eligible stationers, probably a fellow Londoner. ${ }^{76}$ Even if ownership of the right were fragmented among

\footnotetext{
${ }^{73}$ See, e.g., Rose, supra note 27 , at $12-13$; Birrell, supra note 33 , at 51 .

${ }^{74}$ See generally Patterson, supra note 36 , at 46 (describing transactions between publishers, printers, and booksellers).

${ }^{75}$ And perhaps the patent rolls, to ensure that the book was not among those printed under a Royal patent held outside of the Company. See Hunt, supra note 47, at 37-38. Thanks to $\mathrm{H}$. Tomás Gómez-Arostegui for raising this issue.

${ }^{76}$ See generally Birrell, supra note 33 , at $71-73$ (describing the "leading London booksellers" who controlled the Stationers' Company).
} 
multiple owners, they would all be similarly easy to identify and locate. ${ }^{7}$

The Stationers' Company era is better remembered, however, as a cautionary tale about the costs of holism-or, more precisely, of certain mechanisms that maintain holistic copyright but sacrifice other important values. The holism of this era was achieved largely through the monopolistic practices of the Stationers' Company, with the encouragement of royal censors. ${ }^{78}$ It intentionally undermined competition and free speech, ${ }^{79}$ and it did little to promote authorial autonomy. Authors' rights were still limited to simple manuscript ownership, ${ }^{80}$ their publishing outlets were limited by the Company's monopsony, and they were the ultimate objects of the Crown's censorship.

\section{B. The Early Modern Era: Eighteenth-Century Great Britain Under the Statute of Anne}

Due in part to objections to both censorship and monopoly in the late seventeenth century, ${ }^{81}$ the final licensing act protecting the Stationers' Company's monopoly expired in $1695 .^{82}$ But some features of the regime were eventually replicated in 1710, after many failed proposals, with the passage of the Statute of Anne.

${ }^{77}$ This is not to say there were not disputes or instances of unclear ownership. Despite the Company's entry requirement, the Register was not in fact comprehensive; and the printing patents, copyrights, and licenses issued by the Crown, the Stationers' Company, and religious authorities sometimes overlapped and conflicted in confusing ways. See, e.g., Hunt, supra note 47 , at 30 (documenting instances of overlapping printing patents).

${ }^{78}$ On the relationship between the Company and royal censorship, see, e.g., Kaplan, supra note 43, at 3; Rose, supra note 27, at 15; Howard B. Abrams, The Historic Foundation of American Copyright Law: Exploding the Myth of Common Law Copyright, 29 Wayne L. Rev. 1119, 1135-36 (1983).

${ }_{79}$ See Samuelson, supra note 35 , at 323 .

${ }^{80}$ See Birrell, supra note 33, at 74 ("[T]he author's copy is the manuscript, and the only way open to him for dealing with that was to sell it out and out . . .."); Cambridge History, supra note 37 , at ch. XVIII, $\S 11$, available at http://bartleby.com/214/ 1811.html.

${ }^{81}$ See generally Simon Stern, Copyright, Originality, and the Public Domain in Eighteenth-Century England, in Originality and Intellectual Property in the French and English Enlightenment 69, 73-76 (2008); Samuelson, supra note 35, at 324.

${ }_{82}$ Raymond Astbury, The Renewal of the Licensing Act in 1693 and its Lapse in 1695, 33 The Libr. 296, 305 (5th Ser. 1978).

${ }^{83}$ See Feather, supra note 33 , at $50-63$. 
The Statute of Anne is often touted as the first modern copyright law ${ }^{84}$ expressly directed not toward censorship and monopoly but instead toward "the encouragement of learning." ${ }^{85}$ In some ways the act did represent a stark break with the past. ${ }^{86}$ But it also maintained elements of the predecessor regime. Its basic scope and subject matter were the same: rights to print and reprint ${ }^{87}$ books and similar writings. ${ }^{88}$ As before, copyright enforcement was conditioned on entry in the Stationers' Company Register. ${ }^{89}$ And for those copyrights already registered and owned by stationers, the Statute extended their rights for twenty-one years. ${ }^{\text {." }}$

On the one hand, this twenty-one year continuation acknowledged and extended stationers' pre-existing claims. On the other hand, it set an expiration date for rights that previously had been understood to be perpetual. ${ }^{91}$ The stationers later argued that the Statute merely augmented common law copyrights that in fact con-

${ }^{84}$ See, e.g., Rose, supra note 27, at 31-48 (describing the promulgation of the Statute of Anne as "[m]aking [c]opyright"); Craig Joyce, The Story of Wheaton v. Peters: A Curious Chapter in the History of Judicature, in Intellectual Property Stories 36, 50 (Jane C. Ginsburg \& Rochelle Cooper Dreyfuss eds., 2006) ("the world's first copyright act"); Samuelson, supra note 35, at 324 ("[t]he principal development that ushered in the modern era of copyright").

${ }^{85}$ An Act for the Encouragement of Learning, by Vesting the Copies of Printed Books in the Authors or Purchasers of such Copies, During the Times therein mentioned, 1710, 8 Anne, ch. 19, available at www.copyrighthistory.org/cgi-bin/kleioc 10010/exec/showTranscription/"uk_1710"/start/"yes" [hereinafter Statute of Anne].

${ }^{86}$ See Samuelson, supra note 35, at 324.

${ }^{87}$ Statute of Anne, supra note 85. Unauthorized sale of unlawfully printed books was also forbidden. Id. See also Ginsburg, supra note 27, at 646-47 ("The Statute of Anne vested authors and proprietors with the rights to print, reprint and sell. In modern copyright parlance, these are the rights to reproduce and distribute the work.").

${ }^{88}$ The Statute referred expressly to books but was interpreted more broadly to cover other printed matter as well. See discussion infra Subsection II.B.1.

${ }^{89}$ Statute of Anne, supra note 85 ; Patterson, supra note 36 , at 146 . Note, however, Jane Ginsburg's observation that while the new statutory remedies were conditioned on formalities, common law remedies were still available: "[E]ven when it came to published works, the courts concluded that formalities conditioned only the special statutory remedies; common law remedies remained available when the author or proprietor had not registered the work with the Stationers' Company." Ginsburg, supra note 27, at 646.

${ }^{90}$ Statute of Anne, supra note 85; Patterson, supra note 36, at 143.

${ }^{91}$ See Brad Sherman \& Lionel Bently, The Making of Modern Intellectual Property Law: The British Experience, 1760-1911, at 12 (1999) (explaining that the effect of the Statute's provisions was that "by the 1730 s statutory rights over formerly profitable works had begun to lapse"). 
tinued forever, but that position was finally rejected by the House of Lords in the famed case of Donaldson v. Beckett in 1774 (holding that common law copyrights ended upon publication and were replaced with the finite copyrights created by the Statute of Anne).$^{2}$

The other critical innovation in the Statute of Anne was that stationers were no longer the only people eligible to hold copyrights. The Statute granted initial rights to new works not to stationers but to the authors themselves for an initial term of fourteen years and a renewal term of fourteen more years if the author was still living. ${ }^{93}$ References in the Statute to other potential rights holders (for example, "assigns" and "proprietors," among others) suggested that authors were no longer limited by the Stationers' Company monopsony and could transfer their rights to whomever they pleased..$^{94}$ They could also transfer rights multiple times by assigning the initial term but retaining the contingent renewal term and then assigning it separately. ${ }^{95}$

With these core features of the Statute of Anne in mind, let us turn to assessing this era along the three dimensions of atomism.

\section{Proliferation: How Many Works Are Subject to Ownership?}

The Statute of Anne explicitly granted rights only to "books."96 But this language was interpreted broadly enough to cover letters, plays, maps, and sheet music. ${ }^{97}$ In short, it seems to have made

\footnotetext{
${ }^{92}$ (1774) 1 Eng. Rep. 837 (H.L.).

${ }^{93}$ Statute of Anne, supra note 85.

${ }^{94}$ See generally Patterson, supra note 36 , at $145-46$ (citing the many references in the statute to owners other than authors and noting that "[t]he radical change in the statute ... was not that it gave authors the right to acquire a copyright-a prerogative until then limited to members of the Stationers' Company-but that it gave that right to all persons").

${ }^{95}$ Statute of Anne, supra note 85 (providing that after expiration of the initial fourteen-year term, "the sole right of printing or disposing of copies shall return to the Authors thereof if they are then living for another Term of fourteen years").

${ }^{96}$ The preamble does refer, however, to "[b]ooks and other writings." Id.

${ }^{97}$ See generally Michael W. Carroll, The Struggle for Music Copyright, $57 \mathrm{Fla}$. L. Rev. 907, 935-45 (2005) (recounting the history of litigation establishing that musical compositions were protectable under the Statute of Anne); Ginsburg, supra note 27, at 643 (citing early cases recognizing the scope of protected materials); Merges, supra note 9, at 1264 (discussing protection of printed musical compositions under early European copyright law).
} 
copyrights available for all printed matter, just as the Stationers' Company copyrights had. ${ }^{98}$

Initially, the specific titles that were protected by the Statute of Anne were continuous with the Stationers' Company regime as well. In the early decades under the Statute, British publishers focused on reprinting existing works as opposed to producing new ones. Authors such as Shakespeare and Milton were popular and, probably more importantly, the publishers already held the copyrights in their works. ${ }^{99}$ But the end of official state censorship and other eighteenth-century societal and cultural factors spurred growth in literature. New works began to proliferate alongside reprints of old favorites. ${ }^{100}$

The universe of theoretically protectable works thus grew in the first century under the Statute of Anne, not because of expansion in the subject matter of copyright, but because of growth in the number of new works written and published. But proliferation of legally protected works did not in fact grow apace with the growth of literature for two reasons. First, full protection under the Statute was conditioned on compliance with the formality of registration. ${ }^{101}$ Second, copyrights expired so that even protected works fell into the public domain no more than twenty-eight years after their first publication. There was not, therefore, a one-to-one correspondence between creative activity and proliferation of copyrights. The creative marketplace became increasingly crowded, but crowding of the copyright marketplace was not as severe. As we will see, these anti-proliferation features of the Statue of Anne were maintained in early American law but do not characterize contemporary copyright.

\section{Distribution: How Many People Own Rights?}

The Statute of Anne's most notable innovation was the elimination of the Stationers' Company's officially sanctioned monopoly, a change that set the stage for much broader distribution of copy-

\footnotetext{
${ }^{98}$ See Patterson, supra note 36, at 146.

${ }^{99}$ See John Feather, A History of British Publishing 72 (1991).

${ }^{100}$ Id. at $92-93,105$. In particular, the emergence of the novel as a literary form created demand for new works. See id.

${ }^{101}$ Statute of Anne, supra note 85; see also Kaplan, supra note 43, at 7.
} 
right ownership. ${ }^{102}$ The initial practical effect of the new Statute was more modest than this dramatic legal change might suggest, however: authors largely continued to assign their copyrights to the same publishers under the same terms as before. ${ }^{103}$

There are important counter-examples of authors claiming and profiting from their new rights. ${ }^{104}$ In fact, one of the first cases decided under the Statute of Anne was initiated by the executor of an author's estate, not by a publisher..$^{105}$ And some especially savvy and popular authors were able to use copyright to control how their works were exploited. Poet Alexander Pope, for example, "sought to exploit the 1710 Copyright Act to his own advantage.... To protect the artistic integrity of his work, as well as his own income, Pope retained as much control as possible over the publication of his poems." 106

During the course of the eighteenth century, more authors followed Pope's lead. ${ }^{107}$ Ironically, authors' bargaining power was enhanced by the failed eighteenth-century campaign for judicial recognition of a perpetual common law authorial copyright. By rejecting that notion in Donaldson v. Beckett ${ }^{108}$ in 1774, the House of Lords weakened the market power of the London booksellers, which was based in part on their claimed ownership of perpetual rights to popular works for which the statutory copyright had expired. ${ }^{109}$ A more competitive publishing marketplace meant more

\footnotetext{
${ }^{102}$ See Patterson, supra note 36, at 150; Samuelson, supra note 35, at 324.

${ }^{103}$ See, e.g., Birrell, supra note 33, at 95-96; Feather, supra note 99, at 170; Feather, supra note 33, at 79-80; Catherine Seville, Literary Copyright Reform in Early Victorian England: The Framing of the 1842 Copyright Act 152 (1999); Diane Leenheer Zimmerman, Authorship Without Ownership: Reconsidering Incentives in a Digital Age, 52 DePaul L. Rev. 1121, 1140 (2003); see also Patterson, supra note 36, at 152 (explaining that booksellers "insisted on having the copyright before they would consent to publish a work" and that "[i]f the author refused, he ran the risk, if the bookseller accepted at all, of having the promotion of his book ignored").

${ }^{104}$ See Feather, supra note 99, at 123.

${ }^{105}$ Rose, supra note 27, at 49-51 (describing Burnet v. Chetwood, 2 Mer. 441 (1720)). Rose goes on to note, however, that "Burnet v. Chetwood was unusual: most of the early cases that arose under the statute involved major London booksellers seeking injunctions ... against other booksellers." Id. at 51.

${ }^{106}$ Feather, supra note 99 , at 99.

${ }^{107}$ See generally id. at 170 .

${ }^{108}$ (1774) 1 Eng. Rep. 837 (H.L.).

${ }^{109}$ See generally Seville, supra note 103, at 104 (describing the post-Donaldson marketplace, where "[t]he monopoly was significantly weakened, and it was now in the-
} 
potential bargaining partners for authors. ${ }^{110}$ Donaldson also made publishers, who could no longer rely on a perpetual stream of revenue from their old copyrights, more dependent on living authors. All in all, by the end of the eighteenth century, authors in Great Britain were beginning to have some of the clout that the Statute of Anne appeared to give them back in $1710 .{ }^{111}$ Thus, by 1800 , poet Robert Southey could direct his representative to negotiate with several different potential publishers of his epic poem Thalaba, with the instructions to "make the best bargain you can, and on no terms ... sell the copyright." 112

\section{Fragmentation: Among How Many People Is Each Work Divided?}

Tangible/Intangible Fragmentation: The Statute of Anne formalized the notion of intangible rights separate from ownership of physical manuscripts that was introduced in the previous era. These intangible rights were in turn subject to fragmentation between concurrent co-owners and between present and future interest holders.

Concurrent Co-Ownership: The exclusive right to print granted by the Statute of Anne ${ }^{113}$ was subject to co-ownership by multiple

ory possible to publish old books in cheap editions without fear of legal action from the London booksellers").

${ }^{110}$ See generally Feather, supra note 99, at 122 (describing competition from, inter alia, provincial and Scottish publishers).

${ }^{111}$ See Tim Wu, On Copyright's Authorship Policy, 2008 U. Chi. Legal F. 335, 351 (2008). But cf. Seville, supra note 103, at 149 ("With some notable but individual exceptions, most authors continued to sell their copyrights outright until nearly the end of the nineteenth century. Authorship was still relatively young as a profession, and attempts to unite it were, on the whole, unsuccessful."); id. at 153 ("Interest in copyright and related questions grew slowly throughout the early nineteenth century, although at first only a few authors regarded copyright as something worth fighting for.").

${ }^{112} 2$ The Life and Correspondence of Robert Southey 121 (Charles Cuthbert Southey ed., 1849); see also Seville, supra note 103, at 153-54 (describing this episode). On authors' growing bargaining power in the late eighteenth and early nineteenth centuries, see generally Feather, supra note 33, at 123 (describing growing awareness of "the mutual dependence of authors and publishers"); Feather, supra note 99, at 170-71 (documenting pro-author statutory developments); Patterson, supra note 36, at 177-78 (discussing the impact of Donaldson on the booksellers' monopoly).

${ }^{13}$ The Statute of Anne granted exclusive rights to print and reprint and also forbade the knowing sale of unlawful copies. Statute of Anne, supra note 85. See Paul 
people. Like the Stationers' Company Ordinance, the language of the Statute of Anne suggested that, where a copyright was owned by multiple people, printing was forbidden unless the permission of "proprietors" was obtained. ${ }^{14}$ Again, this fragmentation of veto power seems troublingly atomistic in theory. But at least in the early decades under the Statute of Anne, the division of copyrights into shares appears still to have been managed within the closeknit community of stationers, with joint ownership often reflecting cozy joint ventures to facilitate the financing of publishing.

As John Feather explains, even after their officially sanctioned monopoly ended, the stationers maintained "the understanding among the principal copy owners that they would only sell shares to each other." ${ }^{\text {"115 }}$ Feather elaborates:

These transactions took place at private auctions, known as "trade sales" ... . Once a bookseller had been admitted to the sales, he was required to sell any copies which he bought there at a similar sale, a rule which also bound widows and other heirs if they wished to dispose of copies which they inherited. Since most of the really valuable copies were divided into shares, almost all of them passed through the trade sales during the eighteenth century, and contributed to the general pattern of a small group of booksellers who dominated publishing through their ownership of copies .... ${ }^{116}$

Catherine Seville describes the eighteenth century trade sales similarly, while also alluding to the way in which Donaldson's rejection of claims of perpetual ownership of the most valuable copies ultimately opened up fragmented ownership to a broader universe of owners:

Goldstein, Derivative Rights and Derivative Works in Copyright, $30 \mathrm{~J}$. Copyright Soc'y U.S. 209, 211-12 (1982); Samuelson, supra note 35, at 325. It did not by its terms include other now familiar exclusive rights of adaptation, public performance, and display. Note, however, Jane Ginsburg's conclusion that the early cases give an "ambiguous response" to the question of whether there could be extra-statutory recognition of those rights. See Ginsburg, supra note 27, at 646-60.

${ }^{114}$ Statute of Anne, supra note 85 (emphasis added).

${ }^{115}$ Feather, supra note 33, at 66.

${ }^{116}$ Id.; see also id. at 80 ("The trade sales ensured that the most profitable copies, however much they might be subdivided, remained within a comparatively small group of owners."). 
The original intention was to share both risk and expense by dividing copyrights. Copyrights were sold only at trade sales, and admittance to these was strictly controlled. It was the exclusion of the Scottish bookseller, Donaldson, from the sale of the rights of Thomson's The Seasons that led to the great case of Donaldson v. Beckett, and ultimately to the weakening of the system. $^{.17}$

These observations about the trade sales demonstrate how, even after the stationers no longer enjoyed an official monopoly, their collusive practices ensured that copyright ownership was fragmented only among their insular group. As with distribution, this situation changed after Donaldson. ${ }^{118}$

Temporal Fragmentation: The structure of the rights created by the Statute of Anne also raised the possibility of temporal fragmentation of copyrights. For new works, the Statute granted authors a fourteen-year initial term, with another fourteen-year renewal term possible upon registration by a living author. ${ }^{119}$ The copyright to a single work could thus become temporally fragmented if an author assigned the initial term but retained the contingent renewal term for himself (or assigned it to someone else). ${ }^{120}$

This type of temporal fragmentation could have imposed high atomism-related costs on publishers who wished to continue to print works to which they had acquired only the initial terms. Indeed, Alexander Pope was involved in at least one dispute involving uncertainty about who had the rights to publish works he had authored once they entered their renewal terms. ${ }^{121}$ But in the vast

\footnotetext{
${ }^{117}$ Seville, supra note 103, at 102.

${ }^{118}$ See generally Feather, supra note 33, at 94 (describing the transformation of the book trade following Donaldson).

${ }^{119}$ Statute of Anne, supra note 85 (providing that "after the expiration of the said term of fourteen years, the sole right of printing or disposing of copies shall return to the authors thereof, if they are then living, for another term of fourteen years"); see Zimmerman, supra note 103 , at 1138 .

${ }^{120}$ See Feather, supra note 99 , at 103 ("[Pope] used the law to defend his copyrights, and had a crucial role in establishing that after the first 14-year term of protection the rights in a copy reverted to the author, although in fact few if any other authors followed his example.").

${ }^{121}$ This complicated case involved issues of concurrent co-ownership and temporal fragmentation. As Feather recounts:

Gulliver had sold a one-third share in The Dunciad to John Clarke, who subsequently sold it to John Osborne, who, in his turn, sold it to Lintot. Lintot
} 
majority of cases, actual assignment practices alleviated some of these difficulties. ${ }^{122}$ The custom, at least in the early decades under the Statute of Anne, was for authors to assign their contingent renewal terms at the same time, and to the same publishers, as they assigned their initial terms-a practice upheld by the English courts. ${ }^{123}$ Private ordering thus produced temporally unified ownership. Again, this situation would gradually change as the publishing marketplace opened up and authors gained bargaining power in the wake of Donaldson.

\section{Atomism Across Multiple Dimensions}

The defining achievement of the Statute of Anne, at least as it was eventually interpreted in Donaldson, was its elimination of the Stationers' Company monopoly on copyright ownership. ${ }^{124}$ Subject to formalities that limited proliferation to some extent, the legal regime dramatically broadened the potential distribution of ownership in an era of literary growth. The law also potentially changed the impact of fragmentation, as more people became eligible to enter into the complex co-ownership arrangements already established during the Stationers' Company regime.

The atomizing impact of these developments was tempered, however, by countervailing legal and practical circumstances. Consolidation and unification of rights were often achieved through private ordering, especially early on when the stationers used their ongoing ownership of the most valuable copyrights to maintain their oligopolistic control of the publishing industry.

Donaldson and related developments eventually started to make the publishing market more competitive in the late eighteenth cen-

bought this share in January 1740 , and in December 1740 he bought the remaining two-thirds from Gulliver. On that basis he printed an edition, but Pope sued on the grounds that under the Act the rights had reverted to him, as author, when fourteen years had elapsed after publication ....

Feather, supra note 33, at 78-79.

${ }_{122}^{12}$ See generally Seville, supra note 103, at 225 (observing that book trade practices made disputes over temporal fragmentation unlikely).

${ }^{123}$ Rundell v. Murray, (1821) Jac. 310, 4 Burr. 2408, 37 Eng. Rep. 868 (Ch.); Carnan v. Bowles, (1786) 2 Bro. C.C. 80, 29 Eng. Rep. 45 (Ch.); see also Fred Fisher Music Co. v. M. Witmark \& Sons, 318 U.S. 643, 648-49 (1943) (discussing English case law); Zimmerman, supra note 103, at $1138 \mathrm{n} .70$ (discussing the implications of Carnan).

${ }^{124}$ See Patterson, supra note 36 , at 147. 
tury. The distribution and widespread fragmentation that had been only a theoretical possibility became more common, laying the groundwork for increasing atomism that would, as we will see, characterize Anglo-American copyright in the nineteenth century.

If the Stationers' Company regime demonstrated how the benefits of holism can be achieved through state-sanctioned monopoly-at great cost in terms of competition, freedom of speech, and authorial autonomy-the eighteenth-century experience under the Statute of Anne demonstrates how legal changes that appear to impose a more atomistic ownership structure (distributed among individual authors, broken into temporal fragments, etc.) can be susceptible to consolidating and unifying private ordering. This holistic private ordering helps to alleviate the costs otherwise imposed by atomism, but it can also result from and perpetuate collusive practices that echo those of the Stationers' Company era.

At the close of the eighteenth century, it was an open question whether the copyright system established by the Statute of Anne could continue to avoid the difficulties posed by atomism as the publishing marketplace became more competitive and authors gained market power. This was also the point at which the United States inherited the legal structures that the Statute of Anne put in place. In the next Section, I focus on that inheritance and the way the copyright law and marketplace developed in the United States in the nineteenth century.

\section{Nineteenth-Century Copyright in the United States}

The first U.S. copyright statute was the Copyright Act of 1790, in which Congress exercised some of its constitutional authority to "promote the Progress of Science and useful Arts, by securing for limited Times to Authors and Inventors the exclusive Right to their respective Writings and Discoveries." ${ }^{125}$ The 1790 Act was preceded by earlier state laws ${ }^{126}$ and by some piecemeal colonial printing privileges. ${ }^{127}$ But its foremost model was clearly the Statute

\footnotetext{
${ }^{125}$ U.S. Const. art. I, § 8, cl. 8.

${ }^{126}$ See generally Patterson, supra note 36, at 183-92; Oren Bracha, The Ideology of Authorship Revisited: Authors, Markets, and Liberal Values in Early American Copyright, 118 Yale L.J. 186, 198 (2008); Francine Crawford, Pre-Constitutional Copyright Statutes, 23 Bull. Copyright Soc'y U.S. 11, 11-13 (1975).

${ }_{127}$ Bracha, supra note 126 , at 197 \& n. 27.
} 
of Anne, with which it overlapped in terms of its subject matter, the initial distribution and transferability of copyright ownership, and the susceptibility of that ownership to various types of fragmentation. ${ }^{128}$

The 1790 Act granted copyright protection to "map[s], chart[s], [and] book[s]." ${ }^{129}$ As with the Statute of Anne, ${ }^{130}$ this language appears to have been interpreted flexibly to include a range of printed matter including printed plays and sheet music. ${ }^{131}$ The 1790 Act followed the Statute of Anne in bestowing its initial benefit on individual authors, making wide distribution of ownership at least theoretically possible. Also, as in England, copyrights were understood to be assignable. ${ }^{132}$

As for fragmentation of ownership, the 1790 Act was like the Statute of Anne in initially creating a core exclusive right (the right to print verbatim copies) ${ }^{133}$ subject to fragmentation between multiple concurrent owners, and also between current and future interest holders (of fourteen-year initial and renewal terms)..$^{134}$

In light of these formal similarities between the Statute of Anne and the copyright act enacted in the United States in 1790 , my assessment of atomism in the first century of U.S. copyright protection echoes the preceding analysis to some extent. Nevertheless, the U.S. context differed in ways that changed the practical impact

\footnotetext{
${ }^{128}$ See Paul Goldstein, Copyright's Highway 40 (rev. ed. 2003); Patterson, supra note 36, at 199-200; R. Anthony Reese, Innocent Infringement in U.S. Copyright Law: A History, 30 Colum. J.L. \& Arts 133, 148 \& n.58 (2007). But cf. Paul M. Schwartz \& William Michael Treanor, Eldred and Lochner: Copyright Term Extension and Intellectual Property as Constitutional Property, 112 Yale L.J. 2331, 2378 n.271 (2003) ("[T]he fact that the relevant British statute was apparently drawn on as a model does not mean that the Founders (including the members of the First Congress) embraced the worldview and the fears of those who adopted the earlier statute.").

${ }^{129}$ Act of May 31, 1790, ch. 15, § 1, 1 Stat. 124, 124 (repealed 1802) [hereinafter 1790 Act $]$.

${ }^{130}$ See discussion supra Subsection II.B.1.

${ }^{131}$ There is scant early case law on the topic, but Jane Ginsburg reports that "a review of early copyright registration records suggests that 'book' was broadly understood to encompass dramatic and musical works." Ginsburg, supra note 27, at 661 .

${ }^{132}$ See Bracha, supra note 126, at 256-57 (discussing assignability under both the Statute of Anne and the 1790 Act).

${ }^{133}$ The Act established the exclusive rights to "print, reprint, publish, or vend." 1790 Act, supra note $129, \S 1$.

${ }^{134}$ Id.
} 
of the statute..$^{135}$ Moreover, the creative marketplace and the formal law quickly evolved over the course of the nineteenth century, with implications for proliferation, distribution, and fragmentation of copyrights.

\section{Proliferation: How Many Works Are Subject to Ownership?}

The 1790 Act's statutory subject matter of "map[s], chart[s], [and] book[s] ${ }^{136}$ was interpreted to protect a wide range of printed material. ${ }^{137}$ In order to qualify for that protection, works had to be registered with the local district court, proof of registration had to be published in a newspaper, ${ }^{138}$ and the work had to be deposited with the secretary of state. ${ }^{139}$ The 1802 Act added the requirement that published copies of protected works be marked with a copyright notice. ${ }^{140}$

The universe of copyrighted works expanded over the course of the nineteenth century because of changes in both the creative marketplace and the scope of protectable subject matter. The literary publishing industry was experiencing explosive growth ${ }^{141}$ innovations in creative technology (the invention of photography, for example ${ }^{142}$ ) were creating whole new categories of works, and Congress and the courts were expanding protection to cover these new categories. ${ }^{143}$ As the Supreme Court would later observe of these

\footnotetext{
${ }^{135}$ See Goldstein, supra note 128 , at 40 (describing both the similarities between early copyright in the United States and England and the "distinctive forces" that "shaped American copyright law").

${ }^{136} 1790$ Act, supra note $129, \S 1$.

${ }^{137}$ See Ginsburg, supra note 27, at 661 .

${ }^{138} 1790$ Act, supra note $129, \S 3$; see also Wheaton v. Peters, 33 U.S. (8 Pet.) 591, 662 (1834).

${ }^{139} 1790$ Act, supra note $129, \S 4$; see also Wheaton, 33 U.S. at 662.

${ }^{140}$ Act of Apr. 29, 1802, ch. 36, $\S 1,2$ Stat. 171 (1802); see also Wheaton, 33 U.S. at 663.

${ }^{141}$ Bracha, supra note 126 , at $210-11$.

${ }^{142}$ See generally Rodney Carlisle, Scientific American Inventions and Discoveries: All the Milestones in Ingenuity-From the Discovery of Fire to the Invention of the Microwave Oven 246-47, 254 (2004).

${ }^{143}$ In 1802 "historical or other print[s]" were added to the statutory subject matter; in 1831, musical compositions were added; in 1856 dramatic compositions were added (although some courts had already interpreted "books" to include printed music and plays, as noted above); in 1865 photographs and negatives were added; and, in 1870, statues and other works of art were added. See Goldstein v. California, 412 U.S. 546, 562 n.17 (1973).
} 
developments, "[a]s our technology has expanded the means available for creative activity and has provided economical means for reproducing manifestations of such activity, new areas of federal protection have been initiated." ${ }^{144}$

As under the British Statute of Anne during the eighteenth century, however, the practical effects of the expansion of both creativity and subject matter eligibility were limited by the requirements (registration and the other formalities noted above) that ensured that not every instance of creative proliferation yielded ownership proliferation. Indeed, the requirements were imposed more strictly in the United States than in Great Britain, ${ }^{145}$ and many authors did not even attempt to comply. ${ }^{146}$ Others intended to claim their copyrights but made errors that resulted in the forfeiture of their rights. ${ }^{147}$

Thus not every instance of creative proliferation resulted in proliferation of ownership, but copyright registrations did increase rapidly during this period of creative innovation and expansion of publishing. ${ }^{148}$ Of course, works were exiting the copyright universe at the same time: in 1834 the Supreme Court in Wheaton v. Peters rejected the notion of perpetual common law copyright in published works, ${ }^{149}$ echoing the interpretation of the Statute of Anne in Donaldson. The statutory duration had been increased, however, to twenty-eight years (with a possible fourteen-year renewal) in $1831 .{ }^{150}$

\footnotetext{
${ }^{144}$ Id. On the connection between technological developments and expansion of copyrightable subject matter, see generally Peter S. Menell, Envisioning Copyright Law's Digital Future, 46 N.Y.L. Sch. L. Rev. 63, 63 (2003).

${ }^{145}$ See Kaplan, supra note 43, at 26-27; Ginsburg, supra note 27 , at 660 ; Joyce, supra note 84 , at 74 .

${ }^{146}$ B. Zorina Khan, The Democratization of Invention 237 (2005); Reese, supra note 128 , at $136-39$.

${ }^{147}$ Khan, supra note 146 , at 245 (describing disputes resulting from inadvertent failure to comply with requirements).

${ }^{148}$ Id. at 237.

${ }^{149} 33$ U.S. (8 Pet.) 591 (1834).

${ }^{150} 1831$ Copyright Act (Act of Feb. 8, 1831), ch. 16, $\S \S 1-2,4$ Stat. 436, 436-37 (repealed 1870).
} 


\section{Distribution: How Many People Own Rights?}

Like the Statute of Anne, the Copyright Act of 1790 bestowed its initial benefit on individual authors, making wide distribution of ownership at least theoretically possible. Here, the solicitude for authors may have been more genuine than it initially was under the Statute of Anne. As Paul Goldstein reports, "[w]riters, not booksellers, led the drive for copyright in the United States." 151 And authors featured in many of the formative controversies over the meaning of the 1790 Act. ${ }^{152}$ The relative centrality of authors to the initial U.S. copyright scheme is not surprising. There was no publishing monopoly along the lines of the Stationers' Company. And, as noted above, even in Great Britain authors were gaining esteem and bargaining power by the late eighteenth century.

Despite the more favorable environment for authors, the early practice in the United States was also for authors to assign their copyrights to publishers. ${ }^{153}$ The relatively competitive market conditions, however, made this private ordering tend less toward consolidation than it did under early British practice, however ${ }^{154}$ Furthermore, over the course of the nineteenth century some U.S. authors were able to follow the lead of English innovators like Alexander Pope by retaining and managing their own copyrights. ${ }^{155}$

\footnotetext{
${ }^{151}$ Goldstein, supra note 128 , at 40 ; see also Feather, supra note 33 , at 151 (" $\mathrm{Al}$ though clearly based on the 1710 British Act, American law went further in specifically recognizing the rights of the author.").

${ }^{152}$ See, e.g., Wheaton, 33 U.S. at 593-95; Stowe v. Thomas, 23 F. Cas. 201 (C.C.E.D. Pa. 1853). But cf. Khan, supra note 146, at 239 ("[T] he fraction of copyright plaintiffs who were authors (broadly defined) was initially quite low, and fell continuously during the nineteenth century. By 1900-1909, only 8.6 percent of all plaintiffs in copyright cases were the creators of the item that was the subject of the litigation.").

${ }^{153}$ Many apparently made these assignments even in advance of registration. Khan reports that "in the first decade after the enactment of the statute almost a half of all copyrights were issued to 'proprietors' such as publishers, rather than authors." Khan, supra note 146, at 236; see also Bracha, supra note 126, at $253 \mathrm{n} .278$ (regarding interpretation of this data). See generally id. at 256 (discussing assignability in England and the United States).

${ }^{154}$ Still, in the United States "[t]he early publishing industry was a small and closeknit community, in which infringement was easy to detect and prosecute privately." "[F]ew conflicts were recorded in the formal legal system in the antebellum period." And "fewer than eight hundred copyright disputes were brought before the courts between 1790 and 1909." Khan, supra note 146, at 238 .

${ }^{155}$ See, e.g., Hellmut Lehmann-Haupt, The Book in America: A History of the Making and Selling of Books in the United States 112 (2d ed. 1951) ("Emerson, for exam-
} 
These practices, combined with the advent of new creative technologies and the expanding literary marketplace documented above, appear to have resulted on balance in wider distribution of ownership in nineteenth-century America than in either of the eras surveyed above.

\section{Fragmentation: Among How Many People Is Each Work Divided?}

The 1790 Act was initially interpreted to grant exclusive rights to print verbatim copies, but not to extend to what we now call derivative works. ${ }^{156}$ This interpretation limited the potential for one type of fragmented concurrent ownership, as the controversial 1853 case Stowe v. Thomas demonstrates. ${ }^{157}$ In Stowe, the court held that the preparation of a German translation of Uncle Tom's Cabin did not infringe the copyright in the original because "[ $t]$ he same conceptions clothed in another language cannot constitute the same composition, nor can it be called a transcript or 'copy' of the same 'book."' 158 Under this rule, a subsequent author could translate, abridge, and make other derivative uses of a copyrighted work without asking permission from the original author. The second author would then hold an independent and unified copyright in the new work. The two independent copyrights would correspond oneto-one to the separate works, with ownership of each unified in a

ple, shrewdly increased the return from his books by the expedient of paying for their manufacture, and gave his publisher only a commission on their sales. Longfellow and Prescott owned the plates of their works, and sold printing rights to the publishers."); R. Anthony Reese, The Story of Folsom v. Marsh: Distinguishing Between Infringing and Legitimate Uses, in Intellectual Property Stories, supra note 84, at 259, 262-66 (describing Jared Sparks's sophisticated management and division of the copyright to his biography and collection of the papers of George Washington).

${ }^{156}$ See Bracha, supra note 126, at 199-200 (observing that "the notion embedded in the traditional scheme adopted by the 1790 Act was that of an exclusive right of making verbatim copies of a particular text"); see also Reese, supra note 128, at 142; Alfred C. Yen, Restoring the Natural Law: Copyright as Labor and Possession, 51 Ohio St. L.J. 517, 534 n.119 (1990).

${ }^{157} 23$ F. Cas. 201 (C.C.E.D. Pa. 1853).

${ }^{158}$ Id. at 207. See generally Oren Bracha, Commentary on Stowe v. Thomas (1853), in Primary Sources on Copyright (1450-1900) (L. Bently \& M. Kretschmer eds., 2008), available at http://www.copyrighthistory.org/cgibin/kleioc/0010/exec/ausgabe Com/\%22us_1853b\%22; Goldstein, supra note 113, at 213. 
single owner, not fragmented between the authors of the old and new elements.

The one-dimensionality of the exclusive right under the 1790 Act also limited the extent to which initially unified copyrights were fragmented through subsequent transfers. As Abraham Kaminstein, who served as Register of Copyrights from 1960-1971, ${ }^{159}$ later reflected, "[w]hen copyright consisted solely in the right to multiply copies, transfers were generally of the entire copyright; as long as the rights and the uses of copyright material remained few, the problems incident to transferring one of a bundle of rights were of little consequence." ${ }^{160}$

Over the course of the nineteenth century, however, the nature of the exclusive rights granted by U.S. copyright law changed dramatically. Even before Stowe, more expansive views of copyright holders' exclusive rights were being articulated. For example, the seminal 1841 case Folsom v. Marsh ${ }^{161}$ is best known for Justice Story's ${ }^{162}$ articulation of the concept of "fair use" as a limitation on copyright that could apply, for example, to "a fair and bona fide abridgment of an original work." ${ }^{163}$ But the fact that Story considered a new work that merely incorporated elements of an existing work to be potentially within the exclusive rights of the copyright holder in the first place reflected a newly expansive view of those rights. ${ }^{164}$

This and other judicial expansions of copyright holders' exclusive rights were confirmed in subsequent case law and statutory amendments in the late nineteenth and early twentieth centuries. ${ }^{165}$ In 1856 copyright holders' exclusive rights were expanded to cover

\footnotetext{
${ }^{159}$ See United States Copyright Office, Abraham L. Kaminstein, http://www.copyright.gov/history/bios/kaminstein.pdf (last visited Nov. 19, 2009).

${ }_{160}$ Abraham L. Kaminstein, Senate Judiciary Committee, 86th Cong., Study No. 11 Divisibility of Copyrights, in Copyright Law Revision Studies Nos. 11-13, at 1 (1960).

${ }^{161} 9$ F. Cas. 342 (C.C.D. Mass. 1841) (Story, J., riding circuit).

${ }^{162}$ Justice Story was the Supreme Court Justice assigned to ride circuit in Massachusetts. See Reese, supra note 155, at 271.

${ }^{163}$ Folsom, 9 F. Cas. at 345.

${ }^{164}$ See Reese, supra note 155, at 260; Bracha, supra note 126, at 229; L. Ray Patterson, Folsom v. Marsh and Its Legacy, 5 J. Intell. Prop. L. 431, 432 (1998); L. Ray Patterson, Free Speech, Copyright, and Fair Use, 40 Vand. L. Rev. 1, 40 (1987).

${ }^{165}$ See Bracha, supra note 126, at 230-31; Goldstein, supra note 113, at 211-15.
} 
the right to publicly perform dramatic works; ${ }^{166}$ in 1870 translation and dramatic adaptation were added ${ }^{167}$ in 1897 a public performance right was added for dramatic musical compositions; ${ }^{168}$ the 1909 Act added the right to translate and "make any other version[s]" of literary works ${ }^{169}$ and also introduced the potentially expansive right to "copy ... the copyrighted work." 170

Registrar Kaminstein later observed how the copyright landscape had changed by the end of the nineteenth century:

The turn of the century . . saw copyright departing from its original concentration on the publishing right; it now included rights of translation, dramatization and of public performance in dramatic and musical compositions. Copyright was no longer a single right, but had become an aggregation or bundle of rights, which might conveniently be referred to as "copyright" but was in reality, many copyrights. ... This is a very different situation from 1790 and the single right of publication. ${ }^{17}$

This bundle could be assigned to one or multiple people, resulting in increasingly complex fragmented ownership. ${ }^{172}$ And, in addition to concurrent co-ownership, the 1790 Act created the potential for temporal fragmentation by granting both initial and renewal terms.

\section{Atomism Across Multiple Dimensions}

The 1790 Copyright Act was modeled on the Statute of Anne, and, like its predecessor, it had at its core a fundamentally atom-

\footnotetext{
${ }^{166}$ Act of Aug. 18, 1856, ch. 169,11 Stat. 138; see also Daly v. Palmer, 6 F. Cas. 1132, 1135-36 (C.C.S.D.N.Y. 1868) (No. 3552) (interpreting public performance right); Goldstein, supra note 113 , at $213-15$.

${ }^{167}$ Act of July 8, 1870, ch. $230, \S 86,16$ Stat. 198, 212.

${ }^{168}$ Act of Jan. 6, 1897, ch. 4, § 4966, 29 Stat. 481, 481-82.

${ }^{169}$ Copyright Act of 1909, ch. 320, \& 1(b), 35 Stat. 1075, 1075 [hereinafter 1909 Act]; see also Reese, supra note 155 , at 288 .

${ }^{170} 1909$ Act, supra note 169 , at 1075 . On the expansiveness of the notion of "copying" a "work" (as opposed to "printing" a "book"), see generally Lawrence Lessig, Remix 268-69 (2008); Patterson, Free Speech, Copyright, and Fair Use, supra note 164 , at 37 .

${ }^{171}$ Kaminstein, supra note 160 , at 3.

${ }^{172}$ See, e.g., Carter v. Bailey, 64 Me. 458, 463 (1874) ("[W]henever the legal estate has once vested through a compliance with the statute, it is assignable. The assignment is not limited to one, but may be to more than one-nor to the whole interest, but any owner may sell and assign any aliquot part of his undivided interest.").
} 
istic feature: initial allocation of ownership to individual authors. But, as in Great Britain in the eighteenth century, early practice under the first U.S. copyright act counteracted atomism: failure to satisfy strict formality requirements limited proliferation and private ordering reconsolidated ownership that was distributed by default.

Over the course of the nineteenth century, however, the potential for greater atomism embedded in the statutory scheme began to be realized as new types of creativity were created and protected, as new fragmentary rights were added to the copyright bundle, and as more authors gained the bargaining power to retain distributed control of their copyrights or fragments of them. In light of these developments, the type of piecemeal private ordering that had limited atomism and its consequences in the past became less tenable, triggering the anxiety about atomism that characterized the late nineteenth and early twentieth centuries, the era to which I now turn.

\section{Atomism Anxiety at the Turn of the Twentieth Century}

Courts and legislators of the late nineteenth and early twentieth centuries expressed anxiety about the consequences of this increasingly atomistic copyright and designed doctrinal innovations to address those consequences. These legal changes were accompanied by innovations in holistic private ordering. Here, I highlight several of these developments.

\section{Proliferation: How Many Works Are Subject to Ownership?}

The anxiety to which I refer is most evident in policies addressing distribution and fragmentation, which I discuss in the balance of this Section. These policies can be understood as a counterbalance to continued copyright proliferation in this era. ${ }^{173}$ The 1909 Act included a broad new definition of copyrightable subject mat-

\footnotetext{
${ }^{173}$ See generally Robert P. Merges, One Hundred Years of Solicitude: Intellectual Property Law, 1900-2000, 88 Cal. L. Rev. 2187, 2192-94 (2000) (documenting the expanding coverage of copyright in the early twentieth century to include the products of new creative technologies and observing that copyright in this period "showed an adaptability to new technologies that would serve it well all century long").
} 
ter, namely "all the writings of an author." 174 And it forestalled the expiration of copyright by again extending the duration, to twentyeight years with a possible twenty-eight-year renewal term. ${ }^{175}$

\section{Distribution: How Many People Own Rights?}

Recall that under the Statute of Anne and the Copyright Act of 1790 , ownership was initially distributed broadly but was often subsequently consolidated into the hands of publishers who took assignments from individual authors. ${ }^{176}$ Developments over the course of the nineteenth century began to challenge this solution.

In particular, the products of the growing publishing industry tended increasingly to include collections of the work of many individual authors: anthologies, magazines, encyclopedias, and the like. ${ }^{177}$ Assembling the individually owned rights necessary to exploit these multi-component products became challenging for their publishers, who argued that they "needed some method other than individual assignments to obtain effective ownership of the copyright to the complete project." 178 The problem of assembling assignments could be especially pressing with regard to renewal rights, as the passage of time could make copyright holders difficult to identify and locate, requiring "searching all over the world for widows and legitimate children."

\footnotetext{
${ }^{174} 1909$ Act, supra note $169, \S 4$.
}

${ }^{175}$ Id. \& 23.

${ }^{176}$ See Bracha, supra note 126, at 256-57 (observing that "[assignability] ended up being the major mechanism for mediating the often conflicting demands of authors' ownership and economic exploitation. The early American case law that firmly located ownership in the hands of authors, in the absence of express assignment, was grounded in this framework.").

${ }^{177}$ See Bracha, supra note 126, at 257 ("Economic and creative projects that were based on a collaborative effort of a large number of individuals gradually became more common and more economically significant."); Catherine L. Fisk, Authors at Work: The Origins of the Work-for-Hire Doctrine, 15 Yale J.L. \& Human. 1, 32 (2003) (noting "a rise in the number of cases involving employees who participated in collaborative creative processes"); id. at 68 (observing that "[t]he kinds of materials that were subject to copyright had expanded to include more materials prepared in a collaborative way in a corporate setting").

${ }^{178}$ Fisk, supra note 177, at 63; see also Bracha, supra note 126, at 254-55.

${ }^{179} 1$ Legislative History of the 1909 Copyright Act 56 (E. Fulton Brylawski \& Abe Goldman eds., 1976) (statement of Samuel J. Elder), quoted in Fisk, supra note 177, at 63. 
This anxiety about the insufficiency of voluntary assignments for assembling rights to collaborative works contributed to judicial and statutory changes that consolidated ownership of both initial and renewal terms through the work-for-hire doctrine. ${ }^{180}$ The doctrine was codified in a provision of the 1909 Act specifying that "the word 'author' shall include an employer in the case of works made for hire." ${ }^{181}$ As Catherine Fisk documents in her historical account, this codification "made concrete, as well as catapulted forward, a change that had just begun in the case law"182 away from a nineteenth-century default rule that individual employee authors were the owners of works they created in the scope of their employment. Under the new rule, this distributed initial ownership was replaced with consolidated employer ownership as a matter of law.

Innovations in Consolidating Private Ordering: Some activities involving the assembly of many separate works happened outside of the work-for-hire context. In these instances, U.S. courts often addressed distribution by accommodating consolidating private ordering. ${ }^{183}$ For example, early twentieth-century cases "strain[ed] to find, in the absence of express language between the parties to the contrary, that a magazine publisher acquired all rights in a contribution from the author." 184

${ }^{180}$ Cf. Robert P. Merges, The Law and Economics of Employee Inventions, 13 Harv. J.L. \& Tech. 1, 4 (1999) (observing in the related area of ownership of inventions, that "[t]he law of employed inventors implicitly addresses one key concern of anticommons theory. The prevailing legal regime solves the post-grant transactional bottleneck by permitting enforceable pre-assignment contracts. These agreements square away ownership issues-thus preventing costly bargaining breakdown-before property rights are granted."); id. at 12 ("At the most basic level, the difference between employer and employee ownership is a matter of transaction costs.").

${ }^{181} 1909$ Act, supra note $169, \S 62$.

${ }^{182}$ Fisk, supra note 177 , at 62 .

${ }^{183}$ For an interesting discussion of the consolidation techniques employed by a purely private, norm-based system for protecting intellectual creations, see Dotan Oliar \& Christopher Sprigman, There's No Free Laugh (Anymore): The Emergence of Intellectual Property Norms and the Transformation of Stand-Up Comedy, $94 \mathrm{Va}$. L. Rev. 1787, 1865 (2008) ("Comedians' norms regarding joint authorship, works made for hire, and transfer of material all work to concentrate ownership in a single rightsholder and constrain the choices comedians have in structuring property rights.").

${ }_{184} 3$ Melville B. Nimmer \& David Nimmer, Nimmer on Copyright § 10.01 (Matthew Bender, rev. ed.). 
At the same time, copyright owners were finding new ways to streamline and systematize the process of transacting with wouldbe licensees of their rights. ${ }^{185}$ The foremost example of innovative private ordering in this era was the formation in 1914 of the ASCAP. ${ }^{186}$

ASCAP was formed by owners of musical composition copyrights (both individual composers and music publishers) eager to enforce the public performance rights that had been created in 1897. After organizing a series of lawsuits to confirm their right to object to the performance of their compositions in restaurants and similar venues, the group established a mechanism that alleviated the transaction costs that might otherwise have made it difficult for those venues (and, later, radio stations) to license the rights to perform a wide variety of songs owned by distributed individuals. ${ }^{187}$

Initially, ASCAP accomplished this through straightforward voluntary consolidation: copyright owners licensed to ASCAP the

${ }^{185}$ Robert Merges lauds strong and exclusive intellectual property rights in part for the way in which the transaction costs they impose encourage this type of private ordering, an observation that suggests that extreme atomism may sometimes be selfcorrecting. See Merges, Contracting into Liability Rules, supra note 12, at 1296-97, 1302-03; cf. Merges, supra note 7, at 184 (suggesting that "the increasing importance of the public domain may represent a partial self-correcting impulse in the IP system").

In conversation about an earlier draft of this article, Eric Talley has made a related point: that the cycles of atomism and holism that I observe in the copyright arena more generally may reflect the fact that holistic policies become politically palatable only when atomism becomes extreme.

${ }^{186}$ On the history of ASCAP, see generally The American Society of Composers, Authors and Publishers, ASCAP History, http://www.ascap.com/about/history (last visited Nov. 18, 2009); Goldstein, supra note 128, at 54-61; Merges, Contracting Into Liability Rules, supra note 12 , at 1329-40; Robert P. Merges, The Continuing Vitality of Music Performance Rights Organizations (June 11, 2008) (unpublished manuscript, available at http://repositories.cdlib.org/bclt/lts/49).

${ }^{187}$ See Broad. Music, Inc. v. Columbia Broad. Sys., Inc., 441 U.S. 1, 4-5 (1979) (explaining that ASCAP was formed "because those who performed copyrighted music for profit were so numerous and widespread, and most performances so fleeting, that as a practical matter it was impossible for the many individual copyright owners to negotiate with and license the users and to detect unauthorized uses"). See generally Columbia Broad. Sys., Inc. v. Am. Soc'y of Composers, 400 F. Supp. 737, 741 (S.D.N.Y. 1975); Merges, Contracting Into Liability Rules, supra note 12, at 1331-32 (noting that defendants "often complained about the practical difficulties of policing multiple performances," but that courts considering ASCAP-initiated lawsuits did not "excuse infringement due to the expense of locating and bargaining with copyright holders"). 
exclusive rights of public performance of their songs ${ }^{188}$ Henceforth, only ASCAP could license others to perform the songs in public. ${ }^{189}$ ASCAP in turn granted non-exclusive blanket licenses to performance venues, eliminating the need for costly negotiations with individual copyright holders. ${ }^{190}$ It became a one-stop shop for public performance licensees, who could purchase blanket licenses to every work in the ASCAP catalog.

ASCAP was also the only shop in town-at least until its foremost competitor, Broadcast Music, Inc. ("BMI"), was formed in $1939^{191}$ - and it offered no alternative to a blanket license to its entire catalog. And because its licenses from copyright holders were exclusive,${ }^{192}$ even the copyright holders themselves could not offer licenses on competitive terms. This type of consolidation through private ordering thus harkened back to the collusive practices of the Stationers' Company. ${ }^{193}$

Indeed, ASCAP's practices were soon the object of an antitrust investigation by the Department of Justice. ${ }^{194}$ The resulting consent decree required a non-exclusive licensing scheme, such that (in theory) individual copyright holders could offer licenses on terms that differed from ASCAP's blanket licensing. ${ }^{195}$ ASCAP and BMI con-

${ }^{188}$ See Alden-Rochelle, Inc. v. Am. Soc'y of Composers, Authors and Publishers, 80 F. Supp. 888,891 (S.D.N.Y. 1948).

${ }^{189}$ See id. at 894 (describing exclusivity of ASCAP's licensing authority).

${ }^{190}$ See Columbia Broadcasting, 400 F. Supp. at 742.

${ }^{191}$ See id.

${ }^{192}$ "[P]rior to 1950, ASCAP, for all practical purposes, obtained exclusive rights from its members. The user did not have the alternative of dealing with individual ASCAP members for individual licenses." Simon H. Rifkind, Music Copyrights and Antitrust: A Turbulent Courtship, 4 Cardozo Arts \& Ent. L.J. 1, 7 (1985).

${ }^{193}$ See Goldstein, supra note 128, at 57 ("The logic of ASCAP's operations, particularly the logic of the blanket license, is the logic of monopoly . . . ."); Randal C. Picker, Unbundling Scope-of-Permission Goods: When Should We Invest in Reducing Entry Barriers?, 72 U. Chi. L. Rev. 189, 192-96 (2005) ("[T]he blanket license blocks entry in copyright collectives and may facilitate collusion among music composers.").

${ }^{194}$ Cf. Merges, Contracting Into Liability Rules, supra note 12, at 1388-89 (arguing that "policy makers ought to consider removal of antitrust threats to organizational entrepreneurs.... The antitrust enforcement actions against patent pools and copyright CROs pose very real obstacles for anyone trying to knit firms together in a cooperative licensing venture").

${ }^{105}$ Broad. Music, Inc. v. Columbia Broad., Inc., 441 U.S. 1, 12 (1979) ("[T]he decree guarantees the legal availability of direct licensing of performance rights by ASCAP 
tinue to operate under consent decrees with the Department of Justice. ${ }^{196}$

\section{Fragmentation: Among How Many People Is Each Work Divided?}

The work-for-hire doctrine (described above) is consolidating because it makes an employer the owner of many separate works prepared by individual employees. But it can also operate to unify fragmented ownership where multiple employees have labored together on a single work (a crew working on a movie, for example). By unifying ownership of all such contributions in the hands of the employer, the work-for-hire doctrine limits the costs of assembling the fragmentary rights necessary to exploit such a work. But other fragmentation scenarios occur outside of the work-for-hire context. And so in the same era in which the work-for-hire doctrine arose, other doctrinal developments also addressed anxiety about the atomistic effects of fragmented copyright ownership.

Concurrent Co-Ownership and Joint Authorship: A hint of anxiety about the potential complications caused by fragmented copyright co-ownership is evident in the first reported case in the United States involving the rights of co-owners: Carter v. Bailey, decided by the high court of Maine in $1874 .{ }^{197}$ In ultimately holding that one of several co-owners need neither seek permission from his co-owners before exploiting the work nor account to them for any profits earned, the court expressed anxiety about how fragmented ownership under the contrary rule could create barriers to dissemination of copyrighted works:

The public ... for the addition to its general stock of knowledge, and the author, in consideration of the pecuniary profit derivable

members ...."). But cf. id. at 35-36 (Stevens, J., dissenting) (questioning plausibility of direct licensing); Columbia Broad., 400 F. Supp. at 745-46 (similar).

The relevant provision of the current consent decree is IV.A., which prohibits ASCAP from "[h]olding, acquiring, licensing, enforcing, or negotiating concerning any foreign or domestic rights in copyright musical compositions other than rights of public performance on a non-exclusive basis." United States v. Am. Soc'y of Composers, Authors and Publishers, No. 41-1395, at *6 (S.D.N.Y. June 11, 2001) (order amending final judgment), available at http://www.ascap.com/reference/ascapafj2.pdf.

${ }^{196}$ Am. Soc'y of Composers, No. 41-1395, at *1; United States v. Broad. Music, Inc., 1994 WL 901652, at *1 (S.D.N.Y. Nov. 18, 1994) (order modifying consent decree).

${ }^{197} 64 \mathrm{Me} .458$ (1874). 
therefrom, are jointly interested in the publication of new works... . But if none be allowed to enjoy his legal interest without the consent of all, then one, by withholding his consent, might practically destroy the value of the whole use. ${ }^{198}$

Carter was followed in the early twentieth century by a series of cases in which U.S. courts considered a special type of coownership-that arising not from assignment of a copyright to multiple owners (the apparent situation in Carter $^{199}$ ) but rather from initial authorship of a single work by multiple people. Here too, we see evidence of anxiety about atomism.

The first U.S. case expressly addressing the issue was Maurel $v$. Smith, a dispute between three composers who had all contributed to a single opera. ${ }^{200}$ In his 1915 opinion, Learned Hand established two important and enduring characteristics of copyright joint authorship. First, he approvingly cited English case law for the proposition that joint authorship arises as the product of "a joint laboring in furtherance of a common design." 201 Second, he declared that the result of such joint authorship is that the collaborators "must share alike" in the undivided copyright unless they have expressly agreed otherwise. ${ }^{202}$ Each contribution "merges into the whole, ${ }^{, 203}$ and each owner has the right unilaterally to exploit the entire holistic work.

A series of subsequent Second Circuit opinions expanded the coverage of this joint authorship concept and clearly established its holistic consequences. Analogizing to a tenancy in common in real property, the court affirmed that each owner had an undivided interest in the entire combined work, with the right to exploit the copyright without seeking permission from his co-owners (albeit

\footnotetext{
${ }^{198}$ Id. at 461,463 . See generally George D. Cary, Study No. 12: Joint Ownership of Copyrights, in Staff of S. Comm. on the Judiciary, 86th Cong., Copyright Law Revision: Studies Nos. 11-13, at 83 (Comm. Print 1960); Note, Accountability Among CoOwners of Statutory Copyright, 72 Harv. L. Rev. 1550 (1959).

${ }^{199} 64 \mathrm{Me}$. at 463.

${ }^{200} 220$ F. 195, 199 (S.D.N.Y. 1915), aff'd, 271 F. 211 (2d Cir. 1921) ("I have been able to find strangely little law regarding the rights of joint authors of books or dramatic compositions.").

${ }^{201}$ Id. at 199 (quoting Levy v. Rutley, (1871) 6 L.R.C.P. 523, 529); see also Edward

B. Marks Music Corp. v. Jerry Vogel Music Co., 140 F.2d 266, 267 (1944).

${ }^{202}$ Maurel, 220 F. at 200.

${ }^{203}$ Id. at 201 (citing Wallerstein v. Herbert, (1867) 16 L.T. 453, 454 (Q.B.)).
} 
with a duty to account to them for his profits-a modification of the no-accounting rule of Carter $){ }^{204}$ This form of concurrent ownership involved multiple people, but ownership was not fragmented because no one had an independent right to exclude. The consequence of joint authorship was holistic concurrent ownership.

In these formative cases, the court emphasized the problems that would arise if the works at issue were instead subject to separate claims of individual ownership of their component parts. For example, in Edward B. Marks Music Corp. v. Jerry Vogel Music $\mathrm{Co} .{ }^{205}$ Judge Hand observed that "[t]o allow the author to prevent the composer, or the composer to prevent the author, from exploiting that power to please, would be to allow him to deprive his fellow of the most valuable part of his contribution; to take away the kernel, and leave him only the husk." ${ }^{206}$ Similarly, in the 12th Street Rag case, ${ }^{207}$ the court resisted a result that would give one collaborator a useless atomistic slice of an entire work: "The result reached in the district court would leave one of the authors of the 'new work' with but a barren right in the words of a worthless poem, never intended to be used alone. Such a result is not to be favored." 208

This anxiety about atomism led to increasingly capacious understandings of the "common design" notion adopted in Maurel. In Edward B. Marks, the court established that the coauthors need not engage in any in-person collaboration. ${ }^{209}$ The so-called Melancholy Baby case established that the coauthors need not intend specifically to merge their contributions with those of their putative coauthors; it is enough that they intend their contributions to be

${ }^{204}$ See generally Picture Music, Inc. v. Bourne, Inc., 314 F. Supp. 640, 645-48 (S.D.N.Y. 1970) (summarizing doctrinal development); Cary, supra note 198, at 93-96 (same).

${ }^{205} 140$ F.2d 266 (2d Cir. 1944).

${ }^{206}$ Id. at 267; see also Carter v. Bailey, 64 Me. 458, 463 (1874) ("[I]f none be allowed to enjoy his legal interest without the consent of all, then one, by withholding his consent, might practically destroy the value of the whole use.").

${ }^{207}$ Shapiro, Bernstein \& Co. v. Jerry Vogel Music Co., 221 F.2d 569 (2d Cir. 1955).

${ }^{200}$ Id. at 570.

${ }^{209}$ Edward B. Marks, 140 F.2d at 267 ("[I]t makes no difference whether the authors work in concert, or even whether they know each other; it is enough that they mean their contributions to be complementary in the sense that they are to be embodied in a single work to be performed as such."). 
merged with something else. ${ }^{210}$ The 12 th Street Rag case moved the focus of the intent requirement from the author to the copyright owner. ${ }^{211}$ Thus, by the 1950 s, the joint authorship notion had been expanded to encompass even asynchronous and initially unanticipated collaboration across time and space, yielding unified, holistic group ownership of the resulting combined works, which were not subject to the veto power of any single contributor.

Indivisibility: In addition to these doctrinal developments regarding co-ownership of entire copyrights, there were developments in this era related to fragmentation of the various sticks in the copyright bundle. Specifically, in the early twentieth century, courts interpreted the 1909 Act to establish what came to be known as the "indivisibility" doctrine, which operated as a limit on the extent to which private ordering could result in this type of fragmentation.

The indivisibility doctrine was derived from language in the 1909 Act referring to a single copyright "proprietor." Cases interpreting the Act gave only this proprietor the right to sue for infringement. Purported assignments of individual rights (to publicly perform, but not reproduce copies of, a play, for example) were therefore interpreted as mere licenses that did not give their recipients standing to sue.

The indivisibility rule aimed to avoid fragmentation that would complicate the task of defending against lawsuits and avoiding lawsuits by negotiating for permission to use copyrighted works upfront. ${ }^{212}$ According to the Nimmer treatise's summary of the cases under the 1909 Act, "[t]he purpose of such indivisibility was to protect alleged infringers from the harassment of successive law suits." "213 As Abraham Kaminstein put it in his 1957 study on the issue, "[f]rom the viewpoint of ease of tracing title and purposes of

${ }^{210}$ Shapiro, Bernstein \& Co. v. Jerry Vogel Music Co., 161 F.2d 406, 409-10 (2d Cir. 1946). So, where a publisher replaced the lyrics accompanying a musical composition with new lyrics not contemplated by the original composer, the result was nonetheless a work of joint authorship by the original composer and the new lyricist. Id.

${ }^{211}$ Shapiro, 221 F.2d at 570.

${ }^{212}$ Cf. Mark A. Lemley, Dealing with Overlapping Copyrights on the Internet, 22 U. Dayton L. Rev. 547, 569-72 (1997) (noting the difficulties associated with obtaining permission to use divided copyrights when one activity implicates several owners' rights).

${ }_{213} 3$ Nimmer, supra note $184, \S 10.01[\mathrm{~A}]$. 
suit, it is much simpler to require that only the author or his assignee can control the copyright." 214

Temporal Fragmentation: In contrast to these holistic turn-ofthe-century developments, Congress considered but rejected proposals in the lead-up to the 1909 Act to eliminate temporal fragmentation in the form of the dual copyright term. Indeed, statements in the legislative history emphasize the value of temporal fragmentation of copyrights, using an oft-quoted example from Mark Twain's experience with Innocents Abroad to demonstrate the potential benefit to an author of retaining his renewal term:

Mr. Clemens told me that he sold the copyright for Innocents Abroad for a very small sum, and he got very little out of the Innocents Abroad until the twenty-eight-year period expired, and then his contract did not cover the renewal period, and in the fourteen years of the renewal period he was able to get out of it all of the profits. ${ }^{215}$

Similarly, the congressional reports accompanying the 1909 revision summarized:

Your committee, after full consideration, decided that it was distinctly to the advantage of the author to preserve the renewal period. It not infrequently happens that the author sells his copyright outright to a publisher for a comparatively small sum. If the work proves to be a great success and lives beyond the term of twenty-eight years, your committee felt that it should be the exclusive right of the author to take the renewal term, and the law should be framed as is the existing law, so that he could not be deprived of that right. ${ }^{216}$

Despite Congress's apparent enthusiasm for temporal fragmentation in this context, the Supreme Court ultimately endorsed the kind of temporal unification through private ordering that had been occurring ever since the Statute of Anne. In 1943 the Court held in Fred Fisher Music Co. v. M. Witmark \& Sons that authors

\footnotetext{
${ }^{214}$ Kaminstein, supra note 160 , at 1 (emphasis added).

${ }^{215}$ Hearings Before Committees on Patents on Pending Bills, 60th Cong., 1st Sess. 20 (1908) (Rep. Frank Currier).

${ }^{216}$ H.R. Rep. No. 60-2222, at 14 (1909), reprinted in 6 Legislative History of the 1909 Copyright Act 14 (E. Fulton Brylawski \& Abe Goldman eds., 1976).
} 
could assign their contingent renewal rights along with their initial terms (and insisted that this had been the rule in the United States since the $1790 \mathrm{Act}){ }^{217}$ Critics of the opinion lamented that the Court had undermined the second-bite-at-the-apple policy Congress intended with the dual term of protection. But Justice Frankfurter's opinion stressed the value to both authors and publishers of allowing one big unified and holistic bite. ${ }^{218}$

Tangible/Intangible Fragmentation: A final example of doctrinal change resulting from anxiety about atomism around the turn of the twentieth century brings us back to the issue of fragmentation of intangible copyrights from the right to possess tangible objects. This aspect of fragmentation was addressed in the 1909 Act's codification of the first sale doctrine, providing that the owner of an authorized copy of a copyrighted work may distribute and display that copy publicly notwithstanding the copyright owner's exclusive rights. The statutory provision codified the Supreme Court's 1908 decision in Bobbs-Merrill Co. v. Straus, in which the Court insisted that "one who has sold a copyrighted article, without restriction, has parted with all right to control the sale of it."219

As I have argued elsewhere, the first sale doctrine has the effect of limiting the complexity of the non-possessory rights attached to physical objects that embody copyrighted works. ${ }^{220}$ It limits the degree of fragmentation between tangible and intangible rights by insisting that some rights are always unified with possession of the tangible object that embodies a copyrighted work.

In addition to the statutory first sale doctrine, the judicial "Pushman presumption" was a sort of super-first sale doctrine applicable to unpublished one-of-a-kind works of art, for which transfer of the singular physical object was presumed to transfer the common law copyright as well. ${ }^{221}$ The default for these works was thus as simple as proto-copyright: the owner of the thing owned the copyright.

\footnotetext{
${ }^{217} 318$ U.S. $643,656-58$ (1943).

${ }^{218}$ Id. at 657 ("If an author cannot make an effective assignment of his renewal, it may be worthless to him when he is most in need.").

${ }^{219} 210$ U.S. 339, 350 (1908).

${ }^{220}$ Van Houweling, supra note 17, at 911-14.

${ }^{21}$ Pushman v. N.Y. Graphic Soc'y, 39 N.E.2d 249, 251 (N.Y. 1942).
} 


\section{Atomism Anxiety Across Multiple Dimensions}

U.S. copyright policy in the late nineteenth and early twentieth centuries was marked by an increasing realization of the potential difficulties associated with atomistic ownership of rapidly proliferating copyrights. In several instances, Congress and the courts anticipated these difficulties and responded with doctrinal choices aimed at consolidating and unifying copyright ownership. Private ordering further helped to consolidate control in the hands of institutions like ASCAP.

But this history also hints at some of the unfortunate consequences of holism. ASCAP's consolidation through private ordering was so comprehensive that it raised antitrust concerns that linger to this day (and that, as we shall see, have recently emerged in the context of new efforts at consolidation through private ordering). As for the work-for-hire doctrine and the other developments that simplified and consolidated copyright ownership, they sacrificed authorial autonomy ${ }^{222}$ in ways that can most clearly be examined by turning to the next chapter in copyright history: the Act of 1976.

\section{E. The 1976 Act and the Age of the Author}

The anti-atomism efforts just described came at the expense of other important copyright values. Most notably, authors who wanted autonomous control over their copyrights objected to work-for-hire and other policies that advantaged publishers and other copyright intermediaries-objections that produced something of a backlash when the next comprehensive copyright revision finally came to fruition in $1976 .{ }^{223}$ As Jane Ginsburg and Robert Gorman put it:

With the enactment of the 1976 Copyright Act, and its amendments, Congress has-at a number of important points-focused upon potential tensions in the interests of authors and publishers, and has for the most part placed its weight behind the former.

\footnotetext{
${ }^{222}$ See generally Ginsburg, supra note 20 , at 1089 (criticizing the work-for-hire doctrine's failure to protect individual human authors).

${ }^{223}$ On the negotiations and compromises that produced the 1976 Act, see generally Jessica D. Litman, Copyright, Compromise, and Legislative History, 72 Cornell L. Rev. 857 (1987).
} 
Courts too ... have been asked to rule upon conflicts between authors and publishers, and have tended to find in favor of the authors. ${ }^{224}$

Lydia Loren also notes "the emphasis the 1976 Copyright Act placed on the author of a copyrighted work." She explains that "[i]n many different provisions of the 1976 Act the author is given protection against certain rules from the 1909 Act that were seen as unfair. In particular, many of these rules related to the relationship between author and publisher/distributor." 225 Similarly, the Supreme Court's opinion in New York Times Co. v. Tasini observes, citing the views of two Registers of Copyright, that the 1976 Act evinced "intent to enhance the author's position vis-à-vis the patron." 226

Evidence of this attentiveness to authorial autonomy, even at the risk of increased atomism, is apparent across multiple dimensions.

\section{Proliferation: How Many Works Are Subject to Ownership?}

The 1976 Act's definition of copyrightable subject matter was broad and inclusive. ${ }^{227}$ The Act extended protection to any original work of authorship fixed in a tangible medium of expression. Initially, works that were published had to comply with some (somewhat relaxed) statutory formalities in order to be protected under the 1976 Act. But a series of subsequent revisions designed to bring the United States into compliance with the Berne Convention, and to address complaints that strict formality requirements were traps

${ }^{224}$ Robert A. Gorman \& Jane C. Ginsburg, Authors and Publishers: Adversaries or Collaborators in Copyright Law?, in Benjamin Kaplan et al., An Unhurried View of Copyright Republished (and with Contributions from Friends), at GORGIN-1, GORGIN-2 (2005).

${ }^{225}$ Lydia Pallas Loren, Untangling the Web of Music Copyrights, 53 Case W. Res. L. Rev. 673, 675 (2003); see also id. at 675 n.13 (citing New York Times v. Tasini, the termination of transfer provision, and the elimination of formalities as "evidenc[ing] a preference for authors' rights").

${ }_{226} 533$ U.S. 483, 495 n.3 (2001) (quoting Letter from M. Peters to Rep. McGovern, reprinted in 147 Cong. Rec. E182 (Feb. 14, 2001) (quoting Barbara Ringer, First Thoughts on the Copyright Act of 1976, 22 N.Y.L. Sch. L. Rev. 477, 490 (1977)), observing that the 1976 Act represented "a break with the [sic] two-hundred-year-old tradition that has identified copyright more closely with the publisher than with the author").

${ }^{227}$ See generally Samuelson, supra note 35 , at 331 (tracing the expansion of the subject matter into the contemporary period). 
for unwary authors, gradually eliminated all formalities as prerequisites for protection, making it dramatically easier for works to enter copyright. ${ }^{228}$ It also became harder for copyrights to expire: the 1976 Act replaced the dual term of protection with a unitary term that lasted in most cases for the life of the author plus fifty years.

\section{Distribution: How Many People Own Rights?}

During the debates and studies leading up to the 1976 Act, the consolidating work-for-hire doctrine was criticized as "philosophically indefensible, and undesirable from the viewpoint of public policy. It leads to unnecessary concentration of intellectual works to the detriment of creative people and of the public."2229 The new Act added statutory text that courts understood as narrowing the controversial doctrine (at least as compared to some broad interpretations of the $1909 \mathrm{Act}^{230}$ ), such that ownership of fewer works was consolidated in the hands of publishers, record companies, and the like. ${ }^{231}$

${ }^{228}$ See generally United States Copyright Office, Register of Copyrights, Report on Orphan Works 15-16 (2006); Lessig, supra note 170, at 263; Reese, supra note 128, at 175-78; Christopher Sprigman, Reform(aliz)ing Copyright, 57 Stan. L. Rev. 485, 48788 (2004); cf. id. at 544 (explaining the Berne Convention's "proscription of mandatory formalities" as "a rational response to the difficulty of complying (and maintaining compliance) with differently administered formalities that may have been, absent the Convention, imposed in dozens of national systems, some with registries, some without, and none of which shares information").

${ }^{229}$ John Schulman, Comments and Views Submitted to the Copyright Office on Works Made for Hire and on Commission, in Staff of S. Comm. on the Judiciary, 86th Cong., Copyright Law Revision Studies Nos. 11-13, at 150 (Comm. Print 1960) (commenting on Borge Varmer, Study No. 13, Works Made for Hire and on Commission (1958), in Staff of S. Comm. on the Judiciary, 86th Cong., Copyright Law Revision Studies Nos. 11-13, at 123 (Comm. Print 1958)).

${ }^{230}$ See Jane Ginsburg, Conflicts of Copyright Ownership Between Authors and Owners of Original Artworks: An Essay in Comparative and International Private Law, 17 Colum.-VLA J.L. \& Arts 395, 404 (1993) (noting that the 1976 Act "excludes most commissioned artworks from works made for hire status," but that before the effective date of the 1976 Act "some decisions, particularly in the Second Circuit, did develop a broad application of the works made for hire doctrine to commissioned works").

${ }^{231}$ See Cmty. for Creative Non-Violence v. Reid, 846 F.2d 1485, 1497 n.17 (D.C. Cir. 1988) aff'd., 490 U.S. 730 (1989) (referring to "the substantial cutback of the work for hire doctrine under the 1976 Act"); Litman, supra note 223, at 888-93 (describing compromises that produced the modified work-for-hire provision in the $1976 \mathrm{Act}$ ). 
In addition, the 1976 Act introduced a written instrument requirement for transfers of copyrights ${ }^{232}$ placing a new formal requirement on this mechanism for consolidating ownership through private ordering.

\section{Fragmentation: Among How Many People Is Each Work Divided?}

Concurrent Co-Ownership and Joint Authorship: The 1976 Act and case law interpreting it narrowed the definition of joint authorship in ways that made the doctrine a less powerful anti-atomism tool. In particular, joint authorship status under the definition added by the 1976 Act is triggered in part by the authors' "intention that their contributions be merged into inseparable or interdependent parts of a unitary whole." ${ }^{233}$ In a refutation of the holding in the 12th Street Rag case, ${ }^{234}$ the legislative history indicates that the requisite intention should be measured at the time the authors make their contributions: "The touchstone here is the intention, at the time the writing is done ...."235 As for the substance of the intent, some courts have read the 1976 Act to require not merely the intent to merge the contributions but the intent that the collaborators have the status of coauthors. ${ }^{236}$ In addition, some courts have required putative coauthors to have both made a copyrightable contribution to the work ${ }^{237}$ and to have exercised control over the

${ }^{232} 17$ U.S.C. $\$ 204$ (a) (2006).

${ }^{233} 17$ U.S.C. $\$ 101$ (2006).

${ }^{244}$ Shapiro, Bernstein \& Co. v. Jerry Vogel Music Co., 223 F.2d 252 (2d Cir. 1955).

${ }^{235}$ H.R. Rep. No. 94-1476, at 120 (1976); see also 1 Nimmer, supra note $184, \S 6.03$; Margaret Chon, New Wine Bursting from Old Bottles: Collaborative Internet Art, Joint Works, and Entrepreneurship, 75 Or. L. Rev. 257, 268-69 (1996).

${ }^{236}$ See, e.g., Aalmuhammed v. Lee, 202 F.3d 1227, 1234 (9th Cir. 2000) (holding that "putative coauthors make objective manifestations of a shared intent to be coauthors"); Thomson v. Larson, 147 F.3d 195, 201-02 (2d Cir. 1998); Childress v. Taylor, 945 F.2d 500, 507-08 (2d Cir. 1991).

${ }^{237}$ E.g., Childress, 945 F.2d at 507. But see 1 Nimmer, supra note 184, § 6.07[A][3]; Gaiman v. McFarlane, 360 F.3d 644, 659 (7th Cir. 2004) ("The decisions that say, rightly in the generality of cases, that each contributor to a joint work must make a contribution that if it stood alone would be copyrightable weren't thinking of the case in which it couldn't stand alone because of the nature of the particular creative process that had produced it."). 
creative enterprise as a whole, serving as its "superintendent" or "mastermind." 238

Of course, if collaborators who were denied joint author status under these holdings had no ownership status at all, then the result would be holistic. Despite the multiplicity of creative contributors, the denial of owner status to those who did not qualify as "masterminds" sharing the requisite intent might result in simple and unified copyright (albeit with costs in terms of autonomy and fairness). But, in fact, if a minor contributor of a copyrightable element of a work is denied the status of joint author of the entire work, he is nonetheless the author (and the initial owner) of his fragmentary contribution. ${ }^{239}$ A larger work that incorporates his contribution will be considered a derivative work or a collective work, in which case it cannot be exploited (outside the bounds of fair use or some other exception) without permission from the individual owner. ${ }^{240}$ There is a limited nod to holism in the collective work provision, which provides a statutory presumption that a collective work copyright owner may release a "revision" of the collective work and a "later collective work in the same series" without seeking additional permission from the contributors. ${ }^{241}$ But the Supreme Court in Tasini refused to give a broad reading to "revision," emphasizing the authorial autonomy interests of contributors to collective works despite complaints from the New York Times Co. and other collaborative work publishers about the diffi-

\footnotetext{
${ }^{238}$ E.g., Aalmuhammed, 202 F.3d at 1234.

${ }^{239}$ F. Jay Dougherty, Not a Spike Lee Joint? Issues in the Authorship of Motion Pictures Under U.S. Copyright Law, 49 UCLA L. Rev. 225, 261-62 (2001).

${ }^{240} 17$ U.S.C. $\$ 103$ (2006) ("The copyright in a compilation or derivative work extends only to the material contributed by the authors of such work, as distinguished from the preexisting material employed in the work, and does not imply any exclusive right in the preexisting material."); see Stewart v. Abend, 495 U.S. 207, 223 (1990) ("The aspects of a derivative work added by the derivative author are that author's property, but the element drawn from the pre-existing work remains on grant from the owner of the pre-existing work. ... So long as the pre-existing work remains out of the public domain, its use is infringing if one who employs the work does not have a valid license or assignment for use of the pre-existing work."); Dougherty, supra note 239, at 265; Rochelle Cooper Dreyfuss, Collaborative Research: Conflicts on Authorship, Ownership, and Accountability, 53 Vand. L. Rev. 1161, 1205-06 (2000).

${ }^{241} 17$ U.S.C. $§ 201$ (2006).
} 
culty of assembling and renegotiating the rights to fragmented copyrights. ${ }^{242}$

Indivisibility: As continued development of various new creative technologies increased the value of individual sticks in the copyright bundle, the indivisibility doctrine was criticized as an unjustifiable restraint on commerce that "produced technical pitfalls for both buyers and sellers." 243

The 1976 Act eliminated the doctrine, providing expressly for just the fragmentation that the 1909 Act was interpreted to forbid. Section 201 now provides that "[a]ny of the exclusive rights comprised in a copyright, including any subdivision of any of the rights specified by Section 106, may be transferred as provided . . . and owned separately." 244

Temporal Fragmentation: The 1976 Act eliminated the dual-term system, but re-injected a different mechanism for temporal fragmentation at the service of authors' second bites. ${ }^{245}$ It created a termination of transfer right that allows authors (or their statutory heirs) to reclaim transferred copyrights decades later. ${ }^{246}$ The right is not transferable and persists "notwithstanding any agreement to the contrary." 247 Because the full fragmenting effects of what has been referred to as the "termination-of-transfers time bomb" are only now starting to emerge, ${ }^{248}$ I will return to this topic below in my discussion of atomism in the contemporary copyright environment. ${ }^{249}$

Fragmented Derivative Works: Temporal fragmentation interacts in complicated ways with fragmented ownership of the elements of derivative works. As we have seen, under early interpretations of the 1790 Act the copyright holder's exclusive rights did not extend

\footnotetext{
${ }^{242}$ N.Y. Times Co. v. Tasini, 533 U.S. 483, 504-06 (2001).

${ }^{243} 3$ Nimmer, supra note $184, \S 10.01$ [A].

${ }^{244} 17$ U.S.C. $\$ 201(d)(2)(2006)$.

${ }^{245}$ See generally Litman, supra note 223 , at $891-93$ (describing the negotiations that produced the new provision).

${ }_{246} 17$ U.S.C. $\$ 203$ (2006) (for post-1978 transfers); id. § 304(c) (for pre-1978 transfers).

${ }^{247}$ Id. $\S \S 203(\mathrm{a})(5), 304(\mathrm{c})(5)$.

${ }^{248}$ David Nimmer \& Peter S. Menell, Sound Recordings, Works for Hire, and the Termination-of-Transfers Time Bomb, 49 J. Copyright Soc'y U.S. 387, 387-88, 397 (2001) ("Given the statutory details, termination largely matures as a live possibility in 2003 ....").

${ }^{249}$ See infra Part III.
} 
to translations, abridgements, and other adaptations of works that we would now consider derivative works. Not only was an author of such an adaptation generally not considered an infringer, he was a copyright holder in his own right, with unified rights to the derivative work that were in no way intertwined with the copyright to the original. Ownership became more complicated after copyright holders received the exclusive right to prepare derivative works (which was not referred to in those terms until the 1976 Act but was largely in place by 1909). Now the creator of a derivative work owned the aspects he contributed (assuming he was authorized to create it in the first place) but could exploit the derivative work only to the extent authorized by the original copyright holder. ${ }^{250}$ Thus derivative works were potentially subject to the control of multiple owners.

The doctrinal manifestations of anxiety about this type of fragmented ownership of derivative works did not fully emerge until after the enactment (but before the effective date) of the 1976 Act. In several cases, courts faced the interesting question of how to deal with derivative works that had been created with the authorization of the author for both the initial and renewal terms when the author died before the vesting of the renewal term and his statutory heirs claimed it therefore reverted to them. In Rohauer $v$. Killiam Shows, Inc., ${ }^{251}$ the Second Circuit adopted for such circumstances what came to be known as the "new copyright" or "derivative work independence" could continue to exploit the derivative work without limitation going forward. ${ }^{253}$ The court expressed the fear that the contrary rule

\footnotetext{
${ }^{250} 1909$ Act, supra note $169, \S 6$ ("[Clompilations or abridgments, adaptations, arrangements, dramatizations, translations, or other versions of works in the public domain, or of copyrighted works when produced with the consent of the proprietor of the copyright in such works ... shall be regarded as new works subject to copyright under the provisions of this Act; but the publication of any such new works shall not affect the force or validity of any subsisting copyright upon the matter employed or any part thereof, or be construed to imply an exclusive right to such use of the original works, or to secure or extend copyright in such original works.").

251551 F.2d 484 (2d Cir. 1977).

${ }_{252}^{252}$ See Dougherty, supra note 239, at 250; Loren, supra note 225, at 706.

${ }^{253}$ Rohauer, 551 F.2d at 4.92 (explaining that "we do not believe . . that the vesting of renewed copyright in the underlying work in a statutory successor deprives the proprietor of the derivative copyright of a right, stemming from the . . . 'consent' of the
} 
would leave a derivative work author in danger of losing the value of her investment in the derivative because of the difficulty of identifying and negotiating with the contingent owners of the temporally fragmented renewal term..$^{254}$

The Supreme Court in 1991 rejected this strong anti-atomism position, holding in Stewart $v$. Abend that a license to prepare a derivative work does not entitle the licensee to continue to exploit the derivative work after the renewal term (for a work still governed by the pre-1976 dual term system) reverts to an author or his statutory heirs. ${ }^{255}$ The rights under the license are subject to disruption due to the temporal fragmentation of copyright ownership. The Court thus rejected the Second Circuit's efforts to interpret the renewal provision so as to avoid the adverse consequences of atomism.

The Supreme Court's views in Stewart were influenced by Congress's intervening reassertion of the importance of temporal fragmentation with the termination of transfer provisions of the 1976 Act. ${ }^{256}$ The 1976 provisions did offer some prospective relief for derivative work copyright owners, however:

A derivative work prepared under authority of the grant before its termination may continue to be utilized under the terms of the grant after its termination, but this privilege does not extend to

original proprietor of the underlying work, to use so much of the underlying copyrighted work as already has been embodied in the copyrighted derivative work").

${ }^{254}$ Id. at 493 ("[T] he purchaser of derivative rights has no truly effective way to protect himself against the eventuality of the author's death before the renewal period since there is no way of telling who will be the surviving widow, children or next of kin or the executor until that date arrives."). Lydia Loren elaborates on how the derivative works independence theory also mitigated atomism-related problems for downstream users, who might face high information and transaction costs if use of a derivative work required permission from the owners of the fragments of both the original work embedded in it and the derivative aspects: "[T] he downstream user of a derivative work would not be required to obtain permission from the various copyright owners in the underlying works that may be incorporated in the derivative work. Obtaining permission from the derivative work copyright owner is all that would be required." Loren, supra note 225, at 705; see also Dougherty, supra note 239, at 250.

${ }_{255}^{25} 495$ U.S. 207 (1990).

${ }^{256}$ Id. at 226 ("[I]f the 1976 Act's termination provisions provide any guidance at all in this case, they tilt against petitioners' theory. The plain language of the termination provision itself indicates that Congress assumed that the owner of the pre-existing work possessed the right to sue for infringement even after incorporation of the preexisting work in the derivative work."). 
the preparation after the termination of other derivative works based upon the copyrighted work covered by the terminated grant. ${ }^{257}$

There is another way in which the 1976 Act prevented some types of fragmentation. The Act's derivative work provision made it even clearer than under the 1909 Act that the creator of an unauthorized derivative work would not be an owner of fragments that were intertwined with the copyrighted work. The Act included current Section 103, which provides that "protection for a work employing preexisting material in which copyright subsists does not extend to any part of the work in which such material has been used unlawfully." ${ }^{258}$ This controversial provision ensures that the copyright holder in the original work will remain the sole proprietor of both the work and derivatives that incorporate it, ${ }^{259}$ unless the owner himself chooses to complicate ownership by authorizing someone else to prepare a derivative work. The provision has been given a particularly unifying interpretation in cases like Anderson $v$. Stallone, in which a district court held that no part of an unlawfully prepared derivative work is entitled to copyright protection (rejecting the argument that "part of the work," in the language of the Act, did not use the preexisting copyrighted material). ${ }^{260}$ This result ensures that ownership of a derivative work will not be fragmented between an original and subsequent author without the original copyright owner's authorization, a requirement likely to inhibit fragmentation. ${ }^{261}$ Unifying control over preexisting and de-

${ }^{257} 17$ U.S.C. $\S \S 203(b)(1), 304(c)(6)(A)(2006)$.

${ }^{258}$ Id. $\S 103(\mathrm{a})$; see Mark A. Lemley, The Economics of Improvement in Intellectual Property Law, 75 Tex. L. Rev. 989, 1022-23 (1997) ("The effect of this rule is to allow the original copyright owner to capture the value of even significant improvements made by others.").

${ }^{259}$ That is, there will be no other owner of either the original or derivatives. Whether the original owner in fact owns the derivative aspects, or whether they have no owner, is an interesting question not clearly answered by the statutory text.

${ }^{260}$ No. 87-0592, 1989 WL 206431, at *9 (C.D. Cal. Apr. 25, 1989) (rejecting the argument that "part of the work," in the language of the Act, did not use the preexisting copyrighted material).

${ }^{261}$ Cf. Edmund W. Kitch, The Nature and Function of the Patent System, 20 J.L. \& Econ. 265, 276 (1977) ("No one is likely to make significant investments searching for ways to increase the commercial value of a patent unless he has made previous arrangements with the owner of the patent. This puts the patent owner in a position to coordinate the search for technological and market enhancement of the patent's value 
rivative works in the hands of the original copyright holder comes at a cost, however, in terms of other copyright values. Most notably, this concentration threatens to undermine beneficial competition in the market for improvements. ${ }^{262}$

\section{Atomism Across Multiple Dimensions}

The 1976 Act and subsequent judicial developments can be understood as a backlash against anti-atomism techniques that threatened author autonomy by limiting proliferation of copyrights, consolidating copyright ownership and facilitating consolidating private ordering, and unifying ownership of the multiple sticks in the copyright bundle. Perhaps most dramatically, the amendments to the formality requirements designed to bring the United States into compliance with the Berne Convention led to massive proliferation of copyrights. The atomizing effect of this proliferation was magnified by the elimination or weakening of several of the doctrines that had limited atomism or ameliorated its effects, especially those put into place in the previous era of anxiety about atomism.

These changes do not appear to have resulted from waning anxiety about atomism, but rather from countervailing concern for authors' interests in maintaining the autonomous control that comes from automatic copyright protection and distributed individual ownership of as many fragments as an author wishes to retain. This interest in authorial autonomy looms even larger today, as I discuss below. But it is matched by intensification of the atomizing trends of the previous era, with potentially unjustifiable costs for the copyright system and for individual authors themselves.

\section{ATOMISM AND AUtonomy in the InTERnET AgE}

In this Part, I document how copyright in the contemporary environment is atomistic on every dimension, due to the current state of copyright law and the technological, business, and creative envi-

so that duplicative investments are not made and so that information is exchanged among the searchers.").

${ }^{262}$ See generally Lemley, supra note 258, at 1047; Suzanne Scotchmer, Standing on the Shoulders of Giants: Cumulative Research and the Patent Law, 5 J. Econ. Persp. 29 (1991). 
ronment in which it operates. I observe that the tools that have in the past been deployed to limit atomism and its harmful effects may be ill-equipped to address today's extreme conditions. Either the existing tools simply do not work, or else they pose threats to authorial autonomy, competition, and distributive fairness that are especially troubling in an era in which technology promises to enhance autonomy and diversify creative opportunities.

\section{A. Proliferation}

Developments since 1976 have made it feasible, for the first time, for copyright ownership to proliferate in lockstep with expansions in creativity. In previous eras, some creative works went immediately into the public domain because their authors either intentionally or inadvertently failed to comply with the formality requirements that were prerequisites for copyright protection. Now those formality requirements have all been removed and copyright acquisition is automatic. This is a dramatic change in itself, but its impact in the current creative environment is extraordinary. Combine the ease of copyright acquisition with the technological tools that allow everyone with a computer and Internet access to be an author and publisher, and now everyone is a potential copyright holder, resulting in massive proliferation of copyrights. Although copyright registration is not required, many of these new technologically empowered copyright holders are seeking to register their copyrights in numbers that are overwhelming the Copyright Office and creating an unprecedented backlog. As the Washington Post reported in 2009, "the envelopes just keep coming, threatening to flood the operation," and "the slowdown is frustrating hundreds of thousands of little-known people with big dreams."263

In addition to the growth of copyrightable works and the ease of acquiring copyright protection, copyrights now take even longer to expire than in the past. The Sonny Bono Copyright Term Exten-

\footnotetext{
${ }^{263}$ Lyndsey Layton, ( 2009? Wishful Thinking, Perhaps, as Backlog Mounts, Wash. Post, May 19, 2009, at A1, available at http://www.washingtonpost.com/wp-dyn /content/article/2009/05/18/AR2009051803171_pf.html.
} 
sion Act of 1998 added twenty years to the term of copyright protection-now the life of the author plus seventy years. ${ }^{264}$

In sum, works are flooding into the copyright system and only slowly trickling out, yielding a creative environment that is crowded with works to which the restrictions imposed by copyright apply whether their authors have gone to the trouble of requesting protection or not.

\section{B. Distribution}

The widespread practice of voluntary assignment of authorial copyrights to consolidating intermediaries has, since the Statute of Anne, served to limit the consequences of initially distributed copyright ownership. But technology is allowing many creators to disseminate their work themselves, making it more feasible for authors to retain their own copyrights instead of assigning them to consolidators. Scholars are increasingly publishing their own works in open access repositories. ${ }^{265}$ Independent musicians are managing their own copyrights and operating without record companies. ${ }^{266}$ Organizations like the Free Software Foundation and Creative Commons are encouraging individual authors to manage their copyrights in innovative ways. A project based at Columbia Law School urges authors to "Keep Your Copyrights." 267

${ }^{264} 17$ U.S.C. $\$ 302(a)$; see also id. $\& 302$ (b) ("In the case of a joint work prepared by two or more authors who did not work for hire, the copyright endures for a term consisting of the life of the last surviving author and 70 years after such last surviving author's death."); id. § 302(c) ("In the case of an anonymous work, a pseudonymous work, or a work made for hire, the copyright endures for a term of 95 years from the year of its first publication, or a term of 120 years from the year of its creation, whichever expires first.").

${ }^{265}$ See, e.g., Harvard University Library Office for Scholarly Communication, OpenAccess Policy, http://osc.hul.harvard.edu/OpenAccess/overview.php (last visited Nov. 21, 2009).

${ }_{266}$ See, e.g., Lars Brandle, Radiohead in Direct-Licensing Deal for New CD, Billboard, Oct. 9, 2007, http://www.billboard.com/bbcom/news/article_display.jsp?vnu_co ntent_id=1003655864\#/bbcom/news/article_display.jsp?vnu_content_id=1003655864; Eliot Van Buskirk, Reznor v. Radiohead: Innovation Smackdown, Wired, Mar. 27, 2008, http://www.wired.com/entertainment/music/news/2008/03/reznor_radiohead; Jon Pareles, Frustration and Fury: Take It. It's Free, N.Y. Times, June 8, 2008, at 1 (Arts and Leisure). See Menell, supra note 144, at 189-90 (documenting other examples of musicians exercising independence from record labels).

${ }^{267}$ See Keep Your Copyrights, http://keepyourcopyrights.org/about ("Copyright was designed to serve artists and creators, but if you give everything up, that idea can just 
As we have seen, there was anxiety in the late nineteenth century about the difficulties posed by such broadly distributed copyright ownership-anxiety that influenced the development of the work-for-hire doctrine. But this new wave of distributed creativity is happening largely outside the employment context and the workfor-hire solution. ${ }^{268}$

As for consolidation through private ordering, one challenge in the Internet age is that many of the individuals who engage in the serendipitous creativity that digital technology enables may not see themselves as repeat players with the stake in solving information and transaction costs problems that the cozy club of stationers or the founders of ASCAP had. ${ }^{269}$ In his study of ASCAP and other "intellectual property exchange institutions," Robert Merges predicts that "[o]nly repeated transactions among right holders will give rise to the private institutions discussed in this Article. Oneshot or sporadic interactions do not justify investments in exchange institutions." ${ }^{270}$ To put it another way, today's individual technology-empowered creators may be less likely than more institutionalized repeat players to internalize the costs that retaining atomistic copyrights imposes on the copyright environment as a whole. ${ }^{271}$ At the same time, existing institutions like ASCAP are challenged by the fact that their established licensing practices do not necessarily map well onto contemporary modes of exploitation of copyrighted works, which may implicate multiple rights that no one institution has been authorized to license. ${ }^{272}$

become lip service. Worse, if you give away too many rights, the business to whom you gave up your rights can use your copyrights against you to hinder your later efforts to create or to get paid.").

${ }^{268} \mathrm{Cf}$. Dreyfuss, supra note 240 , at $1203 \&$ n.165 (arguing that the work-for-hire solution is inappropriate where no one entity has the knowledge necessary to maximize the creative value of a collaborative project).

${ }^{269} \mathrm{Cf}$. James Gibson, Once and Future Copyright, 81 Notre Dame L. Rev. 167, 216 (2005) ("[B]ecause modern-day acts of creative expression are so ubiquitous and unremarkable ... we cannot expect a diffuse public to take the time to prioritize the enrichment of the public domain or the digital commons.").

${ }^{270}$ Merges, supra note 12 , at 1319, 1392; Merges, supra note 18 , at 1866 (raising the question "[u]nder what conditions will voluntary transactional institutions take shape?" and observing that "[a]s yet, there is no definitive answer").

${ }^{27}$ Cf. Merrill \& Smith, Optimal Standardization, supra note 13.

${ }^{272}$ See generally Gervais, supra note 12 , at 12 ; Lemley, supra note 212 , at 571 . 
There is nonetheless some contemporary evidence of consolidation through private ordering. ${ }^{273}$ Some Internet-age intermediaries, including the owners of online platforms that host much of today's "user-generated content," do attempt to acquire ownership of individually authored works through terms of service that purport to affect consolidating copyright assignments or licenses. ${ }^{274}$ But these consolidators often encounter objections echoing those that motivated the pro-author shifts in the 1976 Act. ${ }^{275}$ Journalist Nicholas Carr is one of several observers who have characterized (and decried) these practices as "digital sharecropping": "In a twist on the old agricultural practice of sharecropping, the site owners provide the digital real estate and tools, let the members do all the work, and then harvest the economic rewards. ${ }^{, 276} \mathrm{He}$ elaborates:

By putting the means of production into the hands of the masses but withholding from those masses any ownership over the products of their communal work, the World Wide Computer provides an incredibly efficient mechanism for harvesting the economic value of the labor provided by the very many and concentrating it in the hands of the very few. ${ }^{277}$

\footnotetext{
${ }^{273}$ And there are ASCAP-like institutions for some new types of works, as Merges observed even before the Internet became ubiquitous. See Merges, Contracting Into Liability Rules, supra note 12, at 1380.

${ }^{274}$ See Lessig, supra note 170 , at 244 (reporting that twenty-eight percent of remix platforms surveyed in an informal 2007 study gave the artist or remixer "no rights in her work at all"). See generally Deven R. Desai, Property, Persona, and Preservation, 81 Temp. L. Rev. 67 (2008).

${ }^{275} \mathrm{Cf}$. Merges, supra note 186, at 4 (arguing that "[p]roposals to consolidate music rights to facilitate licensing are ... way off the mark" because "songwriters or their representatives would see their interests swept aside by the owners of sound recording copyrights").

${ }^{276}$ Carr, supra note 1 , at 138 ; cf. Billy Bragg, Op-Ed., The Royalty Scam, N.Y. Times, Mar. 22, 2008, at A13, available at http://www.nytimes.com/2008/03/22/opinion/22bragg.html (arguing that social networking site Bebo.com should have paid royalties to the artists who posted their music there when its founders sold the site to AOL for $\$ 850$ million).

${ }^{277}$ Carr, supra note 1, at 142; see also id. ("[B]usinesses are using the masses of Internet gift-givers as a global pool of cut-rate labor."); id. at 147 ("In the YouTube economy, everyone is free to play, but only a few reap the rewards."); cf. Merges, supra note 9, at 1249-50 (observing but not endorsing negative attitudes "about the large entities that amalgamate huge numbers of IP-protected works"). The law and economics literature on sharecropping may offer insights into both the costs and
} 
The social networking platform Facebook encountered this type of resistance to its efforts to exercise consolidated control over the contributions of its millions of subscribers. In early 2009, Facebook attempted to modify its terms of use to ensure that it would continue to have the right (in the form of a perpetual non-exclusive license) to exploit former members' contributions. ${ }^{278}$ It withdrew the change $^{279}$ in the face of user protests charging, for example, that "Facebook owns you." ${ }^{280}$ More recently, Twitter users have started to inquire about their ownership rights. ${ }^{281}$

Although network effects tend to give popular platforms like Facebook and Twitter some market advantages, Internet users do have other options for affordably disseminating their works of authorship, making heavy-handed consolidation less feasible than it was in eras of more concentrated publishing power. Indeed, other platforms ${ }^{282}$ attract users by making a point of disclaiming any rights to their contributions. ${ }^{283}$

The proposed settlement to the class action lawsuit over the Google Book Search project represents another controversial attempt to use (judicially sanctioned) private ordering to address the problems posed by distributed ownership. ${ }^{284}$ Under the terms of the settlement (which was initially filed in October 2008, amended in

benefits of the form of ownership to which Carr analogizes so pejoratively. See generally Ellickson, supra note 11, at 1349.

${ }^{278}$ Brian Stelter, Facebook's Users Ask Who Owns Information, N.Y. Times, Feb. 17,2009 , at B3.

${ }^{279}$ Brad Stone \& Brian Stetler, Facebook Backtracks On Use Terms, N.Y. Times, Feb. 19, 2009, at B1.

${ }^{280}$ Stelter, supra note 278.

${ }^{281}$ E.g., Blog Maverick, The Mark Cuban Weblog, http://blogmaverick.com/2009/03/ 29/are-tweets-copyrighted/ (Mar. 29, 2009, 6:16 PM).

${ }^{252}$ See generally Philip J. Weiser, Law and Information Platforms, $1 \mathrm{~J}$. Telecomm. \& High Tech. L. 1 (2002).

${ }^{283}$ Cf. Bragg v. Linden Research, Inc., 487 F. Supp. 2d 593, 595 (E.D. Pa. 2007) ("In November 2003, Linden announced that it would recognize participants' full intellectual property protection for the digital content they created or otherwise owned in Second Life. As a result, Second Life avatars may now buy, own, and sell virtual goods ranging 'from cars to homes to slot machines."'); Bobby Glushko, Tales of the (Virtual) City: Governing Property Disputes in Virtual Worlds, 22 Berkeley Tech. L.J. 507, 528-29 (2007).

${ }^{284}$ See generally Merges, supra note 9, at $1269 \mathrm{n} .75$ (noting that "the recent settlement between Google and various book publishers over the controversial Google Book Search resource may just contain the germ of a future collective licensing operation"). 
November 2009, and is still pending final judicial approval as of this writing), Google would have the right to assemble and share with subscribers (and, to a more limited extent, the public) a huge database including both public domain and copyrighted material. ${ }^{285}$ Thanks to the opt-out nature of the class action mechanism, Google would not have to locate and negotiate with all of the widely distributed copyright holders in order to proceed with this massive consolidation of copyrighted works. The settlement is thus a powerful antidote to the problems posed by atomism. But it has generated controversy that is reminiscent of centuries-old objections to the Stationers' Company, and of more recent concerns about powerful consolidators like ASCAP. Although Google's licenses to distribute copyrighted works would in theory be nonexclusive, would-be competitors would have little hope of negotiating similarly comprehensive licenses for themselves because some of the copyright holders who are members of the settlement class are impossible to identify and negotiate with individually. As the American Library Association's comments upon the initial settlement proposal note,

[a] class action settlement provided perhaps the most efficient mechanism for cutting the Gordian knot of the huge transactions costs of clearing the rights of millions of works whose ownership often is obscure. However, the class representatives and Google structured the Settlement in such a manner as to give them enormous control over this essential facility. ${ }^{286}$

Harvard historian and university librarian Robert Darnton makes the historical comparison to the Stationers' Company explicit:

${ }^{285}$ Amended Settlement Agreement, The Authors Guild, Inc. v. Google, Inc., No. 05-CIV-8136 (S.D.N.Y. 2009), available at http://www.googlebooksettlement.com/ Amended-Settlement-Agreement.zip; see also Order Granting Preliminary Approval of Amended Settlement Agreement, The Authors Guild, Inc. v. Google, Inc., No. 05CIV-8136 (S.D.N.Y. 2009), available at http://www.googlebooksettlement.com/ 05CV8136_20091119.pdf.

${ }^{286}$ Library Ass'n Comments on the Proposed Settlement at 5, The Authors Guild, Inc. v. Google, Inc., No. 05-CIV-8136 (S.D.N.Y. 2009), available at http://www.arl.org/ bm $\sim$ doc/googlebrieffinal.pdf. 
The eighteenth-century philosophers saw monopoly as a main obstacle to the diffusion of knowledge-not merely monopolies in general . . . but specific monopolies such as the Stationers' Company in London and the booksellers' guild in Paris, which choked off free trade in books.

Google is not a guild, and it did not set out to create a monopoly. On the contrary, it has pursued a laudable goal: promoting access to information. But the class action character of the settlement makes Google invulnerable to competition. Most book authors and publishers who own US copyrights are automatically covered by the settlement. They can opt out of it; but whatever they do, no new digitizing enterprise can get off the ground without winning their assent one by one, a practical impossibility, or without becoming mired down in another class action suit. If approved by the court-a process that could take as much as two years-the settlement will give Google control over the digitizing of virtually all books covered by copyright in the United States. ${ }^{287}$

Pamela Samuelson puts the argument succinctly: "The proposed settlement agreement would give Google a monopoly on the largest digital library of books in the world." ${ }^{288}$ Like ASCAP before it, Google has attracted the attention of antitrust authorities. The

\footnotetext{
${ }^{287}$ Robert Darnton, Google \& the Future of Books, 56 N.Y. Rev. of Books 9, 11 (Feb. 12, 2009), available at http://www.nybooks.com/articles/22281; see also Robert Darnton, Google and the New Digital Future, 56 N.Y. Rev. of Books (Dec. 17, 2009), available at http://www.nybooks.com/articles/23518 (assessing the amended settlement agreement and concluding that it "does not ... differ in essentials" from the original and that "[i]nstead of providing a solution to the problem of orphan works" it "leaves Google in command of their commercialization").

${ }^{288}$ Pamela Samuelson, The Dead Souls of the Google Book Search Settlement, 52 Comm. of the ACM 28, 30 (July 2009); see also Pamela Samuelson, Google Book Search and the Future of Books in Cyberspace, Minn. L. Rev. (forthcoming 2010) (unpublished manuscript, available at http://ssrn.com/abstract=1535067) (reaching similar conclusions with regard to the amended settlement agreement); James Grimmelmann, How to Fix the Google Book Search Settlement, 12 J. Internet L. 1, 14 (2009) ("Google's first-past-the-post status here could easily turn into a durable monopoly."); cf. Peter S. Menell, Knowledge Accessibility and Preservation Policy for the Digital Age, 44 Hous. L. Rev. 1013, 1067 (2007); Merges, supra note 9, at 1269 n.75 (raising but not addressing the question "[w]hether it is wise to concentrate this potentially important transactional infrastructure in a single private firm").
} 
U.S. Department of Justice has opened an antitrust inquiry ${ }^{289}$ and submitted statements to the district court arguing that both the initial and amended settlement proposals raise antitrust concerns due in part to Google's "de facto exclusive rights for the digital distribution of orphan works. ${ }^{, 290}$ The controversy illustrates both the costs of distributed copyright ownership — costs that especially burden massive attempts to assemble collections of copyrighted works - and the threats posed by solutions that give a single intermediary special consolidating power.

\section{Fragmentation}

We see a similar pattern when we turn to the next dimension of atomism: fragmentation.

Concurrent Co-Ownership and "Microworks": The Internet makes it possible for millions of globally dispersed individuals to make copyrightable contributions to a single collaborative work. ${ }^{291}$ Each individual contribution might be quite small (a modest encyclopedia edit, for example) and valuable only when combined with the work of others. But its author could nonetheless be deemed an individual copyright holder with rights to object to exploitation of his fragment of the whole. The work would thus be subject to fragmented concurrent ownership claims that could, ironically, make subsequent collaboration difficult. As Justin Hughes observes:

In our new recombinant culture, digitization allows very small bits and pieces to be copied and reused with extreme ease, while

\footnotetext{
${ }^{289}$ See Miguel Helft, U.S. Opens Inquiry Into Google Books Deal, N.Y. Times, Apr. 29,2009 , at B5.

${ }^{290}$ Statement of Interest of the United States of America Regarding Proposed Class Settlement at 23, The Authors Guild, Inc. v. Google, Inc., No. 05-CIV-8136 (S.D.N.Y. 2009), available at http://www.justice.gov/atr/cases/f250100/250180.pdf; see also Statement of Interest of the United States of America Regarding Proposed Amended Settlement Agreement at 21, No. 05-CIV-8136 (S.D.N.Y. 2010), available at http://www.justice.gov/atr/cases/f255000/255012.pdf (directing the court to the government's earlier submission regarding "the ability of Google, and no other entity, to compete in a marketplace that the parties seek to create" and noting that "[n]othing in the [Amended Settlement Agreement] addresses this concern").

${ }^{291}$ See generally Dreyfuss, supra note 240, at 1182; Jane C. Ginsburg, Putting Cars on the "Information Superhighway": Authors, Exploiters, and Copyright in Cyberspace, 95 Colum. L. Rev. 1466, 1467-68 (1995); Merges, supra note 9, at 1249.
} 
the Internet makes unprecedented amounts of such bits and pieces instantly available for such reuse. If the res of independent copyright protection shrinks to a "microwork," this recombinant culture is burdened. ${ }^{292}$

As we have seen, several doctrines have served in the past to limit fragmented ownership of individual copyrighted works (or, to use Hughes's framework, to limit ownership of "microwork" components of larger works). In particular, the rules governing joint authorship ensure that each of multiple contributors to an integrated work may exploit the entire work (and not merely their individual contribution to it), subject only to a duty to account to coowners for any profits.

But today's authors are likely to collaborate with each other in ways that are not captured by traditional copyright conceptions of joint authorship and the resulting default of joint ownership. ${ }^{293}$ In particular, recall that joint authorship status is triggered in part by the authors' "intention that their contributions be merged into inseparable or interdependent parts of a unitary whole."294 The legislative history of the 1976 Act indicates that the requisite intention should be measured at the time the authors make their contributions. ${ }^{295}$ But it is common today for artists to prepare freestanding copyrightable works and subsequently to post them on the Internet and invite collaboration. The resulting asynchronous collaboration falls outside at least some judicial interpretations of joint authorship. ${ }^{296}$ As Margaret Chon observes, "the joint work category . . .

${ }^{292}$ Hughes, supra note 15, at 579; cf. Nobuko Kawashima, The Rise of 'User Creativity'-Web 2.0 and a New Challenge for Copyright Law and Cultural Policy, Int'l J. of Cultural Pol'y (forthcoming 2009) (unpublished manuscript, available at http://www.serci.org /congress/congress/papers/kawashima.pdf) (describing the emergence of "mini-creators").

${ }^{293}$ Cf. Dougherty, supra note 239 , at 319 ("[B]y creating the additional intent rules and the requirement that a joint author have control over creation of the work, courts effectively eliminate the possibility of a set of default liability rules for highly collaborative works for which such rules could be most useful."). But cf. Ginsburg, supra note 291 , at $1470-71$ (imagining asynchronous online collaboration that would satisfy the joint work definition)

${ }^{244} 17$ U.S.C. $\$ 101$ (2006)

${ }^{295}$ H.R. Rep. No. 94-1476, at 120 (1976) ("The touchstone here is the intention, at the time the writing is done.").

296 "The fact that the identity of such other authors has not been determined at the time of the original creation does not, according to these cases, derogate from their 
seems not to recognize the morphability, flexibility and fluidity of networked digitized works." 297

In addition, recall that some courts have required putative coauthors to have both made a copyrightable contribution to the work and to have exercised control over the creative enterprise as a whole, serving as its "superintendant" or "master mind."298 The small contributions that, say, Wikipedia contributors make are unlikely to qualify the contributors as joint authors of entire Wikipedia entries under these tests. ${ }^{299}$ But because, as Hughes notes, copyright law lacks a coherent "minimum size principle," some such contributions might well qualify as copyrightable individual works, such that exploitation of the entire entry would require permission from many individual authors.

Outside of joint authorship's unifying default ownership rules, unification through private ordering is a potential solution to the difficulties posed by fragmented ownership. But a recent example demonstrates again the likely opposition by individual authors and their advocates to aggressive unification.

In 2007, Lucasfilm, the company that owns the rights to the Star Wars movies, made clips, images, and sound from those movies available for fans to remix into their own digital film collages. As

status as joint authors." 1 Nimmer, supra note $184, \S 6.03$. "But the current Act rejects the further extension of the concept of joint authorship as formulated in ... the ' 12 th Street Rag' case ... [in which] the court held that even if the intent to contribute to a joint work does not exist at the time the author's contribution is initially created, if such intention is subsequently formed by the author or his assignee this will be sufficient to render the resulting combination a joint work." Id.; see also Chon, supra note 235 , at 268-69 ("[C]ourts have construed intent narrowly to mean that all putative joint authors must intend to make a joint work at the time of the creation of that work."). As for the substance of the intent, some post-1976 courts require not merely the intent to merge the contributions, but the intent that the collaborators have the status of joint authors, see, e.g., Aalmuhammed v. Lee, 202 F.3d 1227, 1234 (9th Cir. 2000) ("'P]utative coauthors make objective manifestations of a shared intent to be coauthors."); Thomson v. Larson, 147 F.3d 195, 201-04 (2d Cir. 1998); Childress v. Taylor, 945 F.2d 500 (2d Cir. 1991), a status that is surely not within the contemplation of many of today's independent and serendipitous collaborators.

${ }^{29}$ Chon, supra note 235, at 270 ; see also Dreyfuss, supra note 240 , at $1208-09$. See generally Robert P. Merges, Locke for the Masses: Property Rights and the Products of Collective Creativity, 36 Hofstra L. Rev. 1179, 1180-81 (2008); Merges, supra note 9, at 1273-74.

${ }_{298}^{29 .}$ E.g., Aalmuhammed, 202 F.3d at 1233, 1235.

${ }^{299}$ See generally Dreyfuss, supra note 240 , at 1200 .

${ }^{300}$ Hughes, supra note 15 , at 578 . 
authorized derivative works, the resulting "mashups" were eligible for highly fragmented copyright protection, with ownership of the new elements initially accruing to the fan-authors while ownership of the preexisting material remains with Lucasfilm. ${ }^{301}$ But the Star Wars Site terms of service provided that each mashup author granted Lucasfilm an "exclusive, royalty free, worldwide license in all rights titles and interests of every kind and nature" in the mashup film. ${ }^{302}$ The license was perpetual, irrevocable, and transferable. ${ }^{303}$ Although this did not by its terms purport to be an outright assignment of the entire copyright, it might as well have been. Not only could Lucasfilm exercise and transfer rights that were otherwise exclusive to the copyright holder, it became the exclusive rights holder, who could object to unauthorized copying, etc., even by the mashup author. ${ }^{304}$ In an editorial in the Washington Post, Lawrence Lessig specifically targeted the Star Wars Mashups Terms of Service: "Upload a remix and George Lucas, and only Lucas, is free to include it on his Web site or in his next movie, with no compensation to the creator. ... Put in terms appropriately (for Hollywood) over the top: The remixer becomes the sharecropper of the digital age., ${ }^{305}$ Not only is this practice controversial, it is not clear how it satisfies the written instrument requirement added by the 1976 Act, which requires a writing signed by the copyright owner to effect an exclusive license. ${ }^{306}$

\footnotetext{
${ }^{301} 17$ U.S.C. $\S 103$ (2006).

${ }^{302}$ Star Wars Mashups Terms of Service, http://web.archive.org/web/*/http://www. starwars.com/welcome/about/mashup-copyright.

${ }^{304}$ Note that this is, in a way, a variation on the default regime that governs derivative works. Had Lucasfilm not authorized the mashups, and assuming that they fell outside the bounds of any other exception to copyright's coverage, the ownership provisions of the Copyright Act would deny the mashup authors the status of copyright owners. 17 U.S.C. $\$ 103$ (2006) ("[P]rotection for a work employing preexisting material in which copyright subsists does not extend to any part of the work in which such material has been used unlawfully.").

${ }^{305}$ Lawrence Lessig, Lucasfilm's Phantom Menace, The Wash. Post, July 12, 2007, at A23. Lessig elsewhere notes the connection between such practices and other controversial consolidating techniques: "This trend away from artists owning their creations is not new. It has long been part of commercial creativity. In America, for example, the 'work-for-hire' doctrine strips the creator of any rights in a creative work made for a corporation, vesting the copyright instead in that corporation." Lessig, supra note 170 , at 244 .

${ }^{306} 17$ U.S.C. $\$ \S 101,204$ (2006).
} 
As with Facebook's efforts to use adhesion to its terms of service to consolidate its control over the many different contributions of its millions of subscribers, the Star Wars example illustrates how attempts to use private ordering to unify fragmentary ownership of contributions to collaborative works can encounter resistance from individual creators, and advocates for individual creators, who justifiably value the authorial autonomy over creative fragments that today's technological tools seem to make more sustainable than in the past.

Divisibility: While consolidation through private ordering can be difficult in the digital age, fragmentation through private ordering is widespread. Copyright owners have taken full advantage of the flexibility introduced by abolition of the indivisibility doctrine in the 1976 Act, transferring individual sticks in the copyright bundle in increasingly complex ways. ${ }^{307}$ In addition, the effect of fragmentation of the copyright bundle into separate rights is exacerbated by the often-unanticipated ways in which the fragments interact with new technologies for exploiting works that are subject to fragmented ownership. For example, distribution of a copyrighted work over the Internet may implicate numerous exclusive rights that are held by different people who did not expect their fragments to overlap with each other. ${ }^{308}$

We may be starting to see some judicial reaction to the complexity caused by fragmentation. In Gardner v. Nike, the Ninth Circuit held that an exclusive licensee of only some of the rights included

\footnotetext{
${ }^{307}$ See generally Schwartz, supra note 18 , at 2092-93 (observing that contemporary copyright law "is premised on numerous divisible interests in a given piece of underlying intellectual property").

${ }_{308}$ Mark Lemley explains this growing problem:

[C]onsider the dilemma faced by someone who wishes to make available over the Net a copyrighted work in which ownership rights have been divided. ... $[\mathrm{P}]$ osting such a work may make the individual posting it liable for infringement to several different entities, each of which will claim the exclusive right to authorize the same conduct. For similar reasons, even obtaining a license from the owner of the public display right will not permit the licensee to display the work on the Net, since such a display also makes copies and involves distribution of the work, and those rights may be owned by different parties. In the context of divided ownership, overlapping rights governing the same conduct may serve as a trap for unwary users, even those who have licensed the copyright from "the" owner in good faith.
}

Lemley, supra note 212 , at $570-71$; see also id. at 549 ; Gervais, supra note 12 , at 11 . 
in the copyright bundle may not subsequently transfer that license without the express permission of the original licensor. ${ }^{309}$ The decision, which has been criticized as failing to implement the divisibility policy embodied in the 1976 Act, ${ }^{310}$ seems to reflect anxiety about the atomizing effects that would result if transferred fragments could easily be re-transferred and re-fragmented outside of the control of any one steward. ${ }^{31}$

Customization: This situation would be complicated enough if copyright owners were merely dividing the bundle into the separate rights (to reproduce, to prepare derivative works, etc.) identified in Section 106 of the Copyright Act. But, in fact, technologyempowered authors who self-publish on the Internet are applying the same do-it-yourself spirit to copyright: crafting transfers and licenses that satisfy their particular whims, providing novel definitions of the rights at issue and imposing limits on when, where, how, and under what circumstances transferees and licensees can exploit the covered works. ${ }^{312}$ This proliferation of idiosyncratic copyright forms exacerbates the information cost problems associated with fragmentation. ${ }^{313}$

To take just one example, individual educators and educational institutions are increasingly using the Internet to share teaching materials (entire online courses, lesson plans, teaching texts, etc.). But a recent study finds that the idiosyncratic copyright terms often attached to these materials are difficult to understand and can make it impossible to combine resources in useful ways without running afoul of their terms. ${ }^{314}$

\footnotetext{
${ }^{309} 279$ F.3d 774, 781 (9th Cir. 2002).

${ }^{310}$ See, e.g., Traicoff v. Digital Media, Inc., 439 F. Supp. 2d 872 (S.D. Ind. 2006); 3 Nimmer, supra note 184 , at $\$ 10.02(B)(4)$.

${ }^{311}$ Gardner, 279 F.3d at 781 ("[T]here are strong policy reasons to place the burden on the licensee to get the licensor's explicit consent either during or after contract negotiations. Placing the burden on the licensee assures that the licensor will be able to monitor the use of the copyright. ... It is easy to imagine the troublesome and potentially litigious situations that could arise from allowing the original licensor to be excluded from the negotiations with a sublicensee.").

${ }^{312}$ See generally Van Houweling, supra note 17.

${ }^{313}$ See generally id.; Merrill \& Smith, Optimal Standardization, supra note 13.

${ }^{314}$ A Report from ccLearn to William and Flora Hewlett Foundation, What Status for "Open"? An Examination of the Licensing Policies of Open Educational Organizations and Projects 13-14 (2008), available at http://learn.creativecommons.org/wpcontent/uploads/2009/01/license-mapping-report-15_dec_-2008-black-and-white-v2.pdf;
} 
Temporal Fragmentation: The full fragmenting effects of the termination-of-transfer provisions added by the 1976 Act are just beginning to emerge, as the first termination notices authorized by the Act for post-1978 transfers were sent in 2003 and will take effect in 2013 . $^{315}$

In enacting the provisions in 1976, Congress was clearly keen to promote authorial autonomy and, specifically, the opportunity for a "second bite at the apple" of copyright negotiation. The provisions allow authors and their statutory heirs to terminate transfers notwithstanding any "agreement to the contrary,", ing the type of temporal reunification through private ordering that was endorsed in the Fred Fisher case. As we have seen, such solicitude for authorial autonomy can impose the countervailing costs associated with atomism. ${ }^{317}$ And so it is no surprise that there has again been pressure somehow to enable reunification of temporally fragmented copyrights. This pressure came first from the recording industry, which was especially anxious about the possibility that the numerous individuals who often contribute to a sound recording might be able to disrupt its continued exploitation by exercising their termination rights. ${ }^{318}$ Responding to this concern, Congress in

see also Daniel E. Atkins, et al., A Review of the Open Educational Resources (OER) Movement: Achievements, Challenges, and New Opportunities 27-28 (2007) (describing some of the intellectual property-related challenges faced by the open educational resources movement).

${ }^{315}$ See Nimmer \& Menell, supra note 248 , at $387-88$.

${ }^{316} 17$ U.S.C. $\$ \S 203(a)(5), 304(c)(5)$.

${ }^{317}$ The provision has also been criticized for inadvertently undermining authorial autonomy by limiting the value of the copyright that an author can initially transfer. Cf. Fred Fisher Music Co. v. M. Witmark \& Sons, 318 U.S. 643, 657 (1943) (making a similar argument with regard to the question whether, under the old renewal system, authors should be able to assign their renewal rights in advance). But cf. Lee Anne Fennell, Adjusting Alienability, 122 Harv. L. Rev. 1403, 1448 (2009) ("Interestingly, it is not always clear whether alienability restrictions weaken or strengthen property rights. The ambiguity arises because alienability's value derives not only from the freedom to engage in (and resist) transfers, but also from the ability to extract surplus from those transfers. Certain limitations on transactions that make them less likely to occur can also increase the surplus that a buyer or seller will receive if a transaction does occur.").

${ }^{318}$ See Nimmer \& Menell, supra note 248, at 404 (observing that "[p]roducers, backup musicians, sound engineers, and others [in addition to featured artists] might ... have a right to terminate, which could produce chaos in the exploitation of sound recordings"); id. at 408 (expressing similar concerns raised by the recording industry and the Register of Copyrights). 
1999 amended the work-for-hire definition to add sound recordings to the list of specially commissioned works that could qualify as works made for hire (to which the termination of transfer provisions do not apply) if so designated in an agreement signed by the parties. This amendment made it possible for record companies to establish unified ownership (for the entire copyright term) of sound recordings prepared by teams of individuals, even if (as was increasingly the case in the music industry) those individuals were not record company employees. But the amendment triggered so much controversy, including objections from prominent recording artists, that it was almost immediately repealed. ${ }^{319}$

More recently, courts have managed to re-inject potential for unifying private ordering through controversial interpretations of the termination-of-transfer provisions. For example, in Penguin Group (USA) Inc. v. Steinbeck, the Second Circuit held that author John Steinbeck's grant of an exclusive license to his publisher could be cancelled by his widow (as copyright owner) and replaced with a new license that would not be subject to terminationthereby extinguishing the termination rights held by Steinbeck's multiple statutory heirs and reunifying the rights in the hands of the exclusive publisher. ${ }^{320}$

Tangible/Intangible Fragmentation: Recall that the first sale doctrine injects a bit of holism into the statutory scheme by providing that the owner of a lawfully made physical copy of a copyrighted work may distribute and display it publicly without the permission of the copyright owner. ${ }^{321}$ Tangible ownership is thus unified with these specified rights to use the expressive work-all packaged as a bundle, not atomistic sticks subject to separate transactions.

\footnotetext{
${ }^{319}$ See 1 Nimmer, supra note $184, \S 5.03(B)(2)(a)(i i)$; Nimmer \& Menell, supra note 248 , at 394.

320537 F.3d 193 (2d Cir. 2008). The Ninth Circuit had come to a similar conclusion in Milne v. Steven Slesinger, Inc., 430 F.3d 1036 (9th Cir. 2005), although it later read that precedent quite narrowly in Classic Media, Inc. v. Mewborn, 532 F.3d 978 (9th Cir. 2008). See generally Peter S. Menell \& David Nimmer, Judicial Resistance to Copyright Law's Inalienable Right to Terminate Transfers (Mar. 10, 2009) (unpublished manuscript, available at http://ssrn.com/abstract=1355678); Peter S. Menell \& David Nimmer, Pooh-Poohing Copyright Law's "Inalienable" Termination Rights (Dec. 18, 2009) (unpublished manuscript, available at http://ssm.com/abstract=1525516).

${ }^{321} 17$ U.S.C. $\$ 109$ (2006).
} 
In the contemporary environment, the first sale doctrine's scope (and thus its holistic effect) is limited. First, the doctrine's exemption for distribution and display of lawfully owned copies is ineffective to insulate most digital distribution and display because those actions also implicate the non-exempt reproduction right. ${ }^{322}$ So, for example, a museum may display copyrighted paintings on its walls without the copyright owner's permission, but not on the virtual walls of its website. Doing so involves reproduction of the work onto the computers that host it (and ultimately onto the computers of viewers), and the first sale doctrine does not by its terms apply to the reproduction right. ${ }^{323}$ Furthermore, copyright holders have been attempting (with mixed results) to limit the effect of the first sale doctrine through contractual and quasi-contractual restrictions on display and distribution of copies of their works. ${ }^{324}$

\section{Atomism Across Multiple Dimensions}

Three themes emerge from this survey of atomism in the contemporary copyright environment. First, copyright in the United States is more atomistic on every dimension than it has been in the past. Second, the proliferation, distribution, and fragmentation that we observe today are not easily amenable to the doctrinal or marketplace solutions that evolved in previous eras. Third, recent attempts to address atomism through doctrinal reform or private ordering have often been met with insurmountable and justifiable opposition. This opposition is no surprise in light of the history surveyed above. After all, the holistic practices that characterized the Stationers' Company era avoided the problems associated with at-

${ }^{322}$ On the state of the first sale doctrine in the digital age, see John A. Rothchild, The Incredible Shrinking First-Sale Rule: Are Software Resale Limits Lawful?, 57 Rutgers L. Rev. 1 (2004); R. Anthony Reese, The First Sale Doctrine in the Era of Digital Networks, 44 B.C. L. Rev. 577 (2003); Joseph P. Liu, Owning Digital Copies: Copyright Law and the Incidents of Copy Ownership, 42 Wm. \& Mary L. Rev. 1245, 1303 (2001).

${ }^{323}$ See Reese, supra note 322, at 612.

${ }^{324}$ Compare, e.g., UMG Recordings, Inc. v. Augusto, 558 F. Supp. 2d 1055 (C.D. Cal. 2008) (applying the first sale doctrine to permit transfer of compact disks despite labels purporting to forbid resale or transfer of possession), and SoftMan Prods. Co. v. Adobe Sys. Inc., 171 F. Supp. 2d 1075 (C.D. Cal. 2001) (taking a similar approach with regard to software), with Adobe Sys. Inc. v. One Stop Micro, Inc., 84 F. Supp. $2 d$ 1086 (N.D. Cal. 2000) (rejecting first sale argument in light of end user license agreement terms). 
omism but also devalued authorial autonomy, shielded a small group of London publishers from competition, and facilitated state censorship. These characteristics were objectionable even at the time and eventually led to the repeal of official protection for the stationers' monopoly. They are even more objectionable now. Our contemporary copyright system is built upon the very values of authorial autonomy and encouragement of diverse creative activity that were endangered under the Stationers' Company. ${ }^{325}$ Moreover, today's technological environment makes reliance on a few powerful publishers less necessary than it was when publishing was an expensive commercial affair-less necessary, that is, so long as we can identify other ways to address the problems caused by the atomistic alternative. ${ }^{326}$

\section{Alleviating Atomism While Honoring AUtonomy in CONTEMPORARY COPYRIGHT}

The lesson of this history is largely cautionary: Atomistic copyright causes information and transaction cost problems that can be addressed by limiting proliferation, distribution, and fragmentation of copyright; but the techniques that have been used to impose those limits have been controversial in the past, have triggered the type of backlash exemplified by the 1976 Act, and seem especially inappropriate today. There are, however, some glimmers both in history and in the contemporary copyright environment of more promising solutions to the problems posed by atomism. Here I explore two such possibilities.

Managing the Information Costs of Atomistic Copyright: New technology may make it more plausible than it has been in the past to address the problems caused by atomism directly-that is, to develop mechanisms for managing the information costs imposed by atomism instead of trying to avoid those costs by making copyright

\footnotetext{
${ }^{325}$ See generally Samuelson, supra note 35 .

${ }^{326}$ See id. at 343 ("Copyright's past will unquestionably be a prologue to its future. The principal question is whether modern copyright principles will predominate or whether the law will evolve further toward postmodern structures and practices which pose dangers for free expression values similar to those of the pre-modern copyright regime."). See generally Wu, supra note 111 (arguing in favor of decentralized authorial copyright as a mechanism for promoting competition and innovation in distribution).
} 
more holistic. ${ }^{327}$ There is a lesson from history here: The registration and notice requirements that once limited proliferation of copyrights also provided information that could ease transactions in those copyrights that were created. When those requirements were removed, copyrights both proliferated and became much more difficult to trace and to trade.

It may be politically unfeasible simply to reinstate the strict registration and notice requirements that were abandoned to comply with the Berne Convention. ${ }^{328}$ But an improved voluntary scheme with enhanced incentives for compliance may provide a useful alternative. ${ }^{329}$ And technology could make information-provision more powerful and less onerous and threatening to author autonomy than in the past. ${ }^{330}$ For example, Peter Menell has proposed reinstating the deposit requirement but making it more valuable by requiring digital copies with which to seed a searchable public digital archive. ${ }^{331}$ Lawrence Lessig suggests a similar technologypowered mechanism, whereby "copyright holders would 'register' their work not in the old-fashioned way (by filing a form with the copyright office) but by uploading the works so that servers could take a signature of it, and then add that to the list of creative works monitored for infringement." ${ }^{332} \mathrm{Or}$, instead of a centralized registry,

\footnotetext{
${ }^{327}$ See Robert P. Merges, The End of Friction? Property Rights and Contract in the "Newtonian" World of On-Line Commerce, 12 Berkeley Tech. L.J. 115, 116 (1997) (explaining how some, but not all, types of transaction costs can be reduced in the online environment).

${ }^{328}$ But see Lawrence Lessig, For the Love of Culture: Google, Copyright, and Our Future, New Republic, Feb. 4, 2010, at 29 (arguing for a mandatory registration requirement for domestic authors, which could be imposed consistent with international obligations and also "adopted by every nation within this international regime").

${ }^{329}$ For example, Sprigman suggests:

The simplest solution would be to preserve formally voluntary registration, notice, and recordation of transfers (and reestablish a formally voluntary renewal formality) for all works, including works of foreign authors, but then incent compliance by exposing the works of noncompliant rightsholders to a "default" license that allows use for a predetermined fee.

Sprigman, supra note 228 , at 555 . Sprigman argues that "the better reading of Berne" would permit these "new-style formalities." Id. at 556; see also Gibson, supra note 269, at 221-29; Merges, supra note 327, at 128 ("One approach might be to increase incentives to register, possibly by decreasing liability when infringement involves material unregistered on a centralized electronic copyright database.").

${ }^{330}$ See Sprigman, supra note 228 , at 517 .

${ }^{331}$ Menell, supra note 288, at $1066-67$.

${ }^{332}$ Lessig, supra note 170 , at 265.
} 
information costs could be reduced with machine-readable tags that attach to and travel with digital works. ${ }^{333}$ Advances in "semantic web" standards and technologies promise to make such tags more ubiquitous and recognizable. ${ }^{334}$

The tangible property context offers some precedent for this type of solution: land recording acts facilitate public notice of the status of land titles and encumbrances, addressing some of the information costs that would otherwise be imposed by hidden servitudes and other unusual and fragmentary property interests. ${ }^{335}$ Doctrines aimed at preserving holistic and standardized land ownership have gradually fallen away in light of these alternative mechanisms for addressing the information costs imposed by servitudes. ${ }^{336}$

Coordinating Instead of Consolidating: Instead of consolidating ownership in a few intermediaries, some problems associated with atomism may be avoided by merely coordinating the terms on which distributed individual owners transact. One promising coordination technique builds on contemporary "public licensing" practices.

In its 2008 Jacobsen v. Katzer decision, the Federal Circuit affirmed the technique of public licensing, whereby a copyright holder publicly announces the terms under which her work may be reused by anyone. ${ }^{337}$ When a potential licensee is satisfied with the offered terms, she need not enter into individualized negotiations with the copyright holder. She may simply proceed to use the work as permitted by (but subject to the limitations of) the public li-

\footnotetext{
${ }^{333}$ Provisions of the Digital Millenium Copyright Act protect this type of "copyright management information" from falsification, removal, and alteration. 17 U.S.C. $\S 1202$ (2006). See generally Jane C. Ginsburg, The Right to Claim Authorship in U.S. Copyright and Trademarks Law, 41 Hous. L. Rev. 263, 284 (2004) (discussing the provisions).

${ }^{334}$ See generally Tim Berners-Lee, et al., The Semantic Web, Scientific American, May 2001, at 35.

${ }^{33}$ Lessig, supra note 170 , at 264 (analogizing copyright to tangible property and noting that "[c]opyright law is unique in its failure to impose formalities on property owners"). See generally Van Houweling, supra note 17.

${ }^{336}$ Ellickson, supra note 11, at 1329-30 (documenting ancient examples of "authoritative off-site records of boundaries and owners" and noting that "[t]he efficiency thesis predicts that innovations in technologies for marking, defending, and proving boundaries lead to more parcelization because they reduce the transaction costs of private property regimes"). See generally Van Houweling, supra note 17.

${ }^{337} 535$ F.3d 1373 (Fed. Cir. 2008).
} 
cense. By preemptively waiving an individual copyright holder's right to exclude under specified circumstances, these licenses partially alleviate the costs associated with atomistic copyrights without ceding control to a consolidating intermediary.

The paradigmatic example of copyright public licensing is the GNU $^{338}$ General Public License ("GPL") Free Software Foundation. ${ }^{340}$ The GPL grants permission to copy, distribute, and modify the computer software programs to which it applies, provided that certain requirements are satisfied. ${ }^{341}$ Namely, any copies or modifications that are distributed must be accompanied by their source code and must be available on the GPL's terms ${ }^{342}$ The license announces that any recipient of these copies or modifications "automatically receives a license from the original licensors . . ..."343 So if all goes as provided in the GPL, everyone who receives a copy or modified version of the software also receives a license and her use of the software is subject to the license terms. The GPL is the most prominent license within a family of licenses promulgated by the Free Software Foundation; others include the GNU Free Documentation License ("FDL"), which was designed to apply to software documentation. ${ }^{344}$

Another family of public licenses moves beyond the realm of computer software and into the realm of culture. Creative Commons is a non-profit organization that promotes licenses that are designed to be applied to a variety of copyrightable works, including music, text, images, and movies. ${ }^{345}$ Like the GPL, these licenses

\footnotetext{
${ }^{338} \mathrm{GNU}$ is the software project with which Richard Stallman launched the free software movement. The acronym stands for "Gnu's Not Unix." See Richard Stallman, The GNU Manifesto (1993), http://www.gnu.org/gnu/manifesto.html.

${ }^{339}$ Free Software Foundation, GNU General Public License (Version 3, June 29, 2007), http://www.fsf.org/licensing/licenses/gpl.html [hereinafter GPL].

${ }^{340}$ This description of public licensing borrows from my earlier work on the topic in The New Servitudes, supra note 17, and in Molly Shaffer Van Houweling, Cultural Environmentalism and the Constructed Commons, 70 L. \& Contemp. Probs. 23 (2007).

${ }^{341}$ GPL, supra note 339.

${ }^{342}$ See id. $\$ \S 1-6$.

${ }^{343}$ See id. $\$ 10$.

${ }^{344}$ GNU Free Documentation License, preamble (Version 1.3, Nov. 3, 2008), http://www.fsf.org/licensing/licenses/fdl.html.

${ }_{345}$ Creative Commons, History, http://wiki.creativecommons.org/History (last visited Nov. 22, 2009).
} 
permit copying, distribution, and, in some cases, modification of covered works, subject to certain conditions that copyright holders choose from a menu of terms. ${ }^{346}$ Among these is a "share-alike" provision, which (like the GPL) requires that derivative works be licensed on the same terms ${ }^{347}$ That is, the creator of a derivative work based upon a work licensed under a Creative Commons share-alike license must give other people permission to copy and modify that derivative work subject to the condition that they do the same with their derivative works, and so on. ${ }^{348}$

These public licenses solve some of the problems I associate with copyright atomism. By allowing licensees to bypass individual negotiations with copyright holders, they alleviate search and negotiation costs. The Creative Commons licenses, which can be embedded in digital files so as to be recognizable by search engines, also demonstrate technology's potential (alluded to above) to facilitate improved management of copyright information. ${ }^{349}$ Of course, transaction costs may still arise if the potential licensee wants to do something with the work that is covered by copyright but outside the terms of the public license. But at least some types of reuse can proceed without individual contact or negotiation.

These public licenses do not avoid, and indeed may exacerbate, other costs associated with copyright atomism, howeverspecifically, those costs that stem from the creation of idiosyncratic copyright fragments. Incompatibility between the various varieties of public licenses can make it difficult to combine licensed works, even under circumstances that seem generally consistent with the expressed preferences of the original licensors. For example, both the GPL family of licenses and Creative Commons "share alike" licenses raise the specter of license incompatibility by requiring

\footnotetext{
${ }^{346}$ Creative Commons, Licenses, http://creativecommons.org/about/licenses (last visited Nov. 22, 2009).

${ }^{347}$ Id.

${ }^{348}$ Id. This requirement of identical permissive licensing of derivatives of a licensed work is often referred to as a "copyleft" provision. See, e.g., Lawrence Rosen, Open Source Licensing: Software Freedom and Intellectual Property Law 105-06 (2005); Free Software Foundation, What is Copyleft?, http://www.fsf.org/licensing/essays/ copyleft.html (last visited Nov. 30, 2009).

${ }_{349}$ See generally posting of Leena Rao to TechCrunch, http//www.washingtonpost.com/wpdyn /content/article/2009/07/09/AR2009070902171.html (July 9, 2009, 9:36 EST) (explaining advanced Google images search that allows users to search for images that have been tagged with a license).
} 
that derivative works prepared by the licensee be licensed under the same terms as the licensed work. That means that derivatives based upon GPL-licensed software can only be licensed under the GPL; other licenses-including other licenses that similarly seek to promote the model of open and non-proprietary software development-are incompatible. As for Creative Commons, no two share-alike works can be combined into a new derivative work unless the terms of their respective licenses match. This causes incompatibility even within the Creative Commons system, which offers licensors the choice of two different (non-matching) sharealike licenses. ${ }^{350}$ And there are many other non-Creative Commons licensing possibilities that are similarly incompatible with Creative Commons share-alike licenses.

One way to avoid the incompatibility problem is for an entire community to agree to use one license (or a compatible set of licenses). Institutional intermediaries can play a useful coordinating role here. ${ }^{351}$ Consider the Wikipedia example. Like Facebook and Star Wars mashups, Wikipedia has a copyright policy that specifies the copyright status of contributions to the Wikipedia project. But instead of consolidating rights in the hands of the platform owner in the way that has triggered autonomy-based objections elsewhere, the Wikipedia terms instead merely coordinate the license choices of all contributors by specifying that all text contributed to Wikipedia is available under the same public license. ${ }^{352}$ Within the community of Wikipedia contributors, this coordination solves incompatibility problems that might otherwise be posed by atomistic copyright claimed in inconsistent ways by the myriad contributors to Wikipedia. ${ }^{353}$ Similarly the White House has recently announced

\footnotetext{
${ }^{350}$ See Creative Commons, Licenses, supra note 346; Niva Elkin-Koren, What Contracts Cannot Do: The Limits of Private Ordering in Facilitating a Creative Commons, 74 Fordham L. Rev. 375, 413-14 (2005); Zachary Katz, Pitfalls of Open Licensing: An Analysis of Creative Commons Licensing, 46 IDEA 391, 401-02 (2006).

${ }^{351}$ Rochelle Cooper Dreyfuss refers to these as "'second order solutions:' policies set by institutions that interact with the participants and share their expertise, but which are more responsive to the public interest." Dreyfuss, supra note 240 , at 1182 . On the role of institutions that facilitate intellectual property exchange, see generally Merges, Contracting Into Liability Rules, supra note 12 and Merges, Intellectual Property Rights and the New Institutional Economics, supra note 18, at 1864-67.

${ }^{332}$ Wikipedia, Copyrights, http://en.wikipedia.org/wiki/Wikipedia:Copyrights (last visited Nov. 23, 2009).

${ }^{353}$ See id.
} 
that all public input posted on its whitehouse.gov website is subject to a Creative Commons license. . $^{354}$

Universities often serve as license coordinators as well. Copyrights to MIT's OpenCourseWare materials are generally retained by faculty members but are uniformly licensed under a specified Creative Commons license. ${ }^{355}$ Harvard University's Faculty of Arts and Sciences employs a more strongly consolidating policy: Faculty members grant Harvard nonexclusive licenses to their scholarly articles, which the university may then make available to the public in an "open-access repository.", ${ }^{, 356}$ But in a nod to authorial autonomy, the policy is subject to waiver at faculty member request.

Funding entities can similarly promote coordinated licensing by specifying the terms under which funded research should be released. For example-in a policy that has recently come under legislative attack 357 - the National Institutes of Health ("NIH") now requires that "all investigators funded by the NIH submit or have submitted for them to the National Library of Medicine's PubMed Central an electronic version of their final, peer-reviewed manuscripts upon acceptance for publication, to be made publicly available no later than 12 months after the official date of publication ...."358 Similarly, the European Research Council "requires that all peer-reviewed publications from ERC-funded research projects be deposited on publication into an appropriate research repository where available, such as PubMed Central, ArXiv or an institutional repository, and subsequently made Open Access within 6 months of publication. ${ }^{, 359}$

\footnotetext{
${ }^{354}$ The White House, Copyright Policy, http://www.whitehouse.gov/copyright/ (last visited Nov. 23, 2009).

${ }^{355}$ MIT OpenCourseWare, FAQ: Intellectual Property, http://ocw.mit.edu/OcwWeb /web/help/faq3/index.htm (last visited Nov. 23, 2009).

${ }^{356}$ Harvard University Library Office for Scholarly Communication, The Harvard Open-Access Policies, http://osc.hul.harvard.edu/OpenAccess/overview.php (last visited Nov. 23, 2009).

${ }^{357}$ Fair Copyright in Research Works Act, H.R. 801, 111th Cong. 1st Sess. (2009).

${ }^{358}$ National Institutes of Health, Revised Policy on Enhancing Public Access to Archived Publications Resulting from NIH-Funded Research, http://grants.nih.gov /grants/guide/notice-files/NOT-OD-08-033.html (last visited Nov. 23, 2009).

${ }^{359}$ European Research Council, ERC Scientific Council Guidelines for Open Access (Dec. 17, 2007), http://erc.europa.eu/pdf/ScC_Guidelines_Open_Access_revised_ Dec07_FINAL.pdf.
} 
Another coordination model is suggested by the Copyright Clearance Center ("CCC"), a not-for-profit formed in 1978 that licenses photocopying and digital reproduction of literary works on behalf of copyright-holding authors and publishers. ${ }^{360}$ As described in a study of collective licensing in the United States by Professor Glynn Lunney,

[t] he CCC provides licenses which grant permission to the licensee to reproduce works that are listed with the CCC. The CCC offers two forms of licenses to users: (i) an annual blanket license with a fee set by CCC; and (ii) a per-copy license with the fees set by the individual copyright owners. ${ }^{361}$

Lunney emphasizes this second option, noting that because CCC

does not set price or licensing terms, it is not a collective in the sense that ASCAP, BMI, and SESAC are, but is merely a collecting agent of the copyright owner. So long as CCC allows the individual copyright owners to set their own licensing terms, the anticompetitive potential of the collecting society model is minimal. ${ }^{362}$

CCC's practices are thus more coordinating and less consolidating than ASCAP's, posing less of a threat to both competition and authorial autonomy.

One interesting question raised by the coordination model is how coordinating institutions should be structured to represent their members without giving each individual so much control as to defeat the transaction-cost savings of collective action. ${ }^{363}$ Both Wikipedia and Facebook have recently experimented with member

\footnotetext{
${ }^{360}$ Copyright Clearance Center, About Us, http://www.copyright.com/viewPage.do? pageCode=au1-n (last visited Nov. 23, 2009); see Glynn Lunney, Copyright Collectives and Collecting Societies: The United States Experience, in Collective Management of Copyright and Related Rights 311, 339 (Daniel Gervais ed., 2006).

${ }^{361}$ Lunney, supra note 360 , at 339 .

${ }^{362}$ Id. at 313 (observing that "[a]s a result, CCC is not, as yet, and appears unlikely to be, subject to a consent decree, or other limitations on its licensing practices, as a result of the antitrust laws").

${ }^{363}$ See generally Merges, Locke for the Masses, supra note 297, at 1188-91 (suggesting that "representative people or entities" can act on behalf of groups of "dispersed creators").
} 
voting on potential license changes. ${ }^{364}$ The law and practices of business organizations, homeowners associations, and other institutions that streamline control in situations of atomistic ownership (even including the "English Stock" of the Stationers' Company) may be fruitful sources of alternative solutions. ${ }^{365}$

In addition to coordinating licensing choices so as to avoid idiosyncratic fragmentation and resulting incompatibilities, institutions can also serve as centralized sources of information about individual licensing preferences and prices. Lunney concludes his study of collective licensing practices with an information-focused proposal aimed at addressing the competitive concerns raised by the current ASCAP model:

[W] hat we need is a systematic listing of all the works available for public performance and their corresponding prices . . . By amending the [consent] decrees to require that each ASCAP member or BMI affiliate identify his or her own performance license price(s) for each of his or her works, we can take a real step towards the creation of a competitive alternative to the current CMOs. ${ }^{366}$

\footnotetext{
${ }^{364}$ Regarding the recent vote among the Wikimedia community to make Wikimedia material available under a Creative Commons license as well as the GNU Free Documentation License, see Wikimedia, Licensing Update, http://meta.wikimedia.org/wiki/ Licensing_update (last visited Nov. 23, 2009); Wikipedia, Licensing Update, http://en. wikipedia.org/wiki/Wikipedia:Licensing_update (last visited Nov. 23, 2009).

Regarding the recent vote among Facebook users, who were asked to approve or disapprove of new governance principles, see posting of Riva Richmond to Gadgetwise, http://gadgetwise.blogs.nytimes.com/2009/04/23/facebook-tests-the-power-ofdemocracy/?scp $=6 \& s q=$ facebook \%20vote\&st=cse (Apr. 23, 2009, 13:25 EST) (describing the vote and suggesting that it may be "a sign of more online democracy to come"); Posting of Jenna Wortham to Bits, http://bits.blogs.nytimes.com/2009/04/24/ facebookers-approve-new-policy-still-hate-redesign/?scp=8\&sq=facebook \%20vote\& $\mathrm{st}=\mathrm{cse}$ (Apr. 24, 2009, 14:01 EST).

${ }^{365}$ Thanks to Jill Fisch for helpful conversation on the relevance of these mechanisms for separating ownership from control. See generally Merges, Locke for the Masses, supra note 297 , at 1188-89 (identifying ways in which "the legal system has figured out clever ways to identify, and in some sense construct or constitute, a single focal point entity to represent the larger group," for example, "[t]he Board of Directors of a corporation can act for the entire group of shareholders ...."). Cf. Ellickson, supra note 11, at 1349 (describing "many mechanisms for governing behavior within the boundaries of group land").

${ }^{366}$ Lunney, supra note 360 , at 345 .
} 
The registry envisioned in the proposed Google Book Search settlement may serve this function to some extent. The registry is charged with representing the rightsholders, collecting and distributing payments from Google as called for in the settlement, and maintaining a "rights information database." ${ }^{367}$ The settlement requires that at least some of the information in this database be made publicly available. Specifically,

[t]he Registry will make publicly available whether or not a Book has been registered with the Registry and, for Books that have been registered, the identity of the Registered Rightsholder, unless the Registered Rightsholder requests that such information not be made public for reasonable privacy concerns, as determined by the Registry. ${ }^{368}$

This identifying information could facilitate direct negotiation with copyright holders, even by Google's would-be competitors, thus alleviating some of the concerns raised by less transparent examples of collective rights management.

Despite license coordination and information provision through coordinating institutions of various sorts, confusion and intercommunity incompatibility may persist. ${ }^{369}$ As Rochelle Cooper Dreyfuss points out, "[a] problem with second order private solutions is that more than one entity can formulate them and there is little reason to believe that the formulations will be coordinated, or even consistent, with each other. ${ }^{9370}$ And indeed, license incompatibilities have made it difficult to combine Wikipedia entries with contributions to some other like-minded collaborative projects (although a recent move to "dual-license" Wikipedia under the GPL, FDL, and Creative Commons terms may alleviate this particular difficulty). ${ }^{371}$

\footnotetext{
${ }^{367}$ Amended Settlement Agreement at 80, The Authors Guild, Inc. v. Google, Inc., Case No. 05 CV8136-DC (S.D.N.Y. 2009), available at http://www.googlebooksettlement.com/intl/en/Amended-Settlement-Agreement.zip (last visited Feb. 8, 2010).

${ }^{368}$ Id. at 90.

${ }^{369}$ These problems are discussed in more detail in Van Houweling, supra note 17, at 939-46.

${ }^{370}$ Dreyfuss, supra note 240 , at 1189.

${ }^{371}$ See Wikipedia, Copyrights, http://en.wikipedia.org/wiki/Wikipedia:Copyrights (last visited Feb. 13, 2010).
} 
The compatibility problems encountered by various (proliferating and potentially incompatible) licensing schemes could be solved by license standardization. ${ }^{372}$ Several commentators have proposed this solution. For example, Robert Merges suggests that "the Copyright Act could be amended to provide a statutory 'safe harbor' capturing at least some of the attributes of GPL-type licenses. It would become available simply by following statutory notice provisions, such as affixing an ' $\mathrm{L}$ in a circle' notice (for ' $\mathrm{Lim}$ ited Copyright Claimed-Full Copyright Waived'). ${ }^{, 373}$ Technology that helps to attach and parse various licenses may also help to alleviate both confusion and incompatibility. ${ }^{374}$ The semantic web standards mentioned above are making this type of machinefacilitated interoperability increasingly realistic.

Summarizing Solutions: These two potential approaches to atomism-improved management of information relating to copyright ownership and coordination of the terms under which individual copyright owners make their works available for reusehardly exhaust the possibilities. Other candidates include increasing reliance on liability rules that make negotiations over distributed and fragmented rights unnecessary, ${ }^{375}$ shifting back toward an

${ }^{372}$ See generally Merrill \& Smith, Optimal Standardization, supra note 13 , at $49-51$ (arguing for superiority of government-supplied property standardization over privately supplied standardization).

${ }^{373}$ Merges, supra note 7, at 201-02; see also Posting of James Gibson to the Faculty Blog, University of Chicago Law School, http://uchicagolaw.typepad.com/faculty/ 2008/02/jim-gibsons-com.html (Feb. 5, 2008, 11:45).

${ }^{374} \mathrm{Cf}$. Gervais, supra note 12 , at 20-21 (speculating that "it may be that, with the aid of technology ..., the individual exercise of rights will become not only feasible but a more efficient solution, at least in certain cases"); id. at 23-24 (discussing potential technological improvements to copyright management); Merges, Contracting Into Liability Rules, supra note 12 , at 1380 (observing that "new multimedia exchange mechanisms" have "an extra dimension compared to those of the past: rapid computerized exchange capabilities"); id. at 1381-82 (raising the possibility that decentralized technological exchange systems may arise in lieu of centralized institutions for exchange of intellectual property rights in the digital age); Merges, supra note 186, at 20-22 (describing new technologies employed by performing rights organizations).

${ }^{375}$ See generally Mark A. Lemley \& Philip J. Weiser, Should Property Rules or Liability Rules Govern Information?, 85 Tex. L. Rev. 783 (2007). But cf. Merges, Contracting Into Liability Rules, supra note 12, at 1301-17 (noting the shortcomings of legislatively or judicially imposed liability rules in the intellectual property context). 
opt-in system that effectively limits copyright proliferation, ${ }^{376}$ and relying on voluntary under-enforcement by copyright owners. ${ }^{377}$ Ongoing consideration of the alternatives should be informed by history's demonstration of the costs and benefits of both atomism and holism.

\section{CONCLUSION}

Examining the history of Anglo-American copyright with attention to proliferation, distribution, and fragmentation reveals a recurring tension between anxiety about the costs of atomism and concern with honoring authorial autonomy and other critical copyright values. This tension has contributed to dramatic shifts in legal rules with varying practical effects depending on how those legal changes have interacted with market conditions, social norms, creative practice, and technological innovation.

During the English Stationers' Company regime of the sixteenth and seventeenth centuries, the benefits of holism were achieved through state-sanctioned monopoly at great cost in terms of competition, freedom of speech, and authorial autonomy. In eighteenth-century Great Britain, the apparently atomistic legal changes imposed by the Statute of Anne were counteracted by consolidating and unifying (and collusive) private ordering. The same basic legal regime was imported into the United States in 1790, but its atomistic impact increased over the course of the next century because of evolution in both the law and the creative marketplace in which it operated.

This evolution culminated by the end of the nineteenth century in anxiety about the newly atomistic copyright environment. The resulting doctrinal changes and innovations in private ordering included the codification of the work-for-hire doctrine and the for-

\footnotetext{
${ }^{376}$ See, e.g., Wu, supra note 6 , at 620 (proposing "creation of 'opt-in' copyright enforcement systems that require[] the owner to provide notice before the usage of a work becomes infringing").

${ }^{377}$ See id. at 617-20. Additional solutions are suggested by, for example, Dreyfuss, supra note 240, at 1214-30 (advocating changes in the default rules of patent and copyright to better reflect the realities of contemporary collaboration); Fennell, supra note 12 (describing various techniques for re-configuring property); Zimmerman, supra note 103 (considering the model of up-front payment for artistic production that is then released into the public domain).
} 
mation of voluntary exchange institutions like ASCAP. These developments aimed to address anxiety about atomism but triggered concern about the countervailing norm of authorial autonomy. The 1976 Copyright Act and subsequent judicial developments can be understood partly as a backlash against the pursuit of holism at the expense of authors.

Today, the pro-author changes embedded in the 1976 Act have combined with changes in the technological, business, and creative environment to produce extreme atomism on every dimension. Contemporary copyright atomism is fostered, in part, by the do-ityourself spirit of the Internet age. Ironically, it also endangers Internet-empowered individual creativity by increasing the costs and complexity of participating in the creative marketplace.

It may be time for both copyright doctrine and practice to respond, as they have in the past, to changes in the balance of atomism's costs and benefits. But the history I have surveyed suggests that some techniques for managing atomism may be ineffective or inappropriate in today's environment. From the Stationers' Company, to the work-for-hire doctrine, to recent attempts to consolidate copyright ownership with heavy-handed terms of use, efforts to counteract the harmful effects of atomism have sacrificed authorial autonomy, competition, and free expression. The Internet age offers unprecedented potential for realizing these important values. The next task is to craft solutions to the challenges posed by atomistic copyright that do not squander this potential. That effort should be informed by history's lessons about the tension between autonomy and atomism and about the sometimes unintended consequences of attempts to resolve it. 